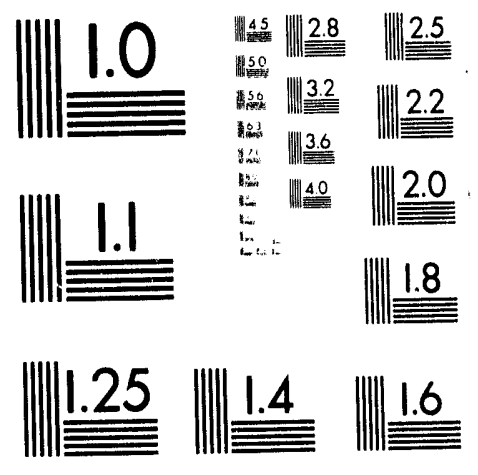



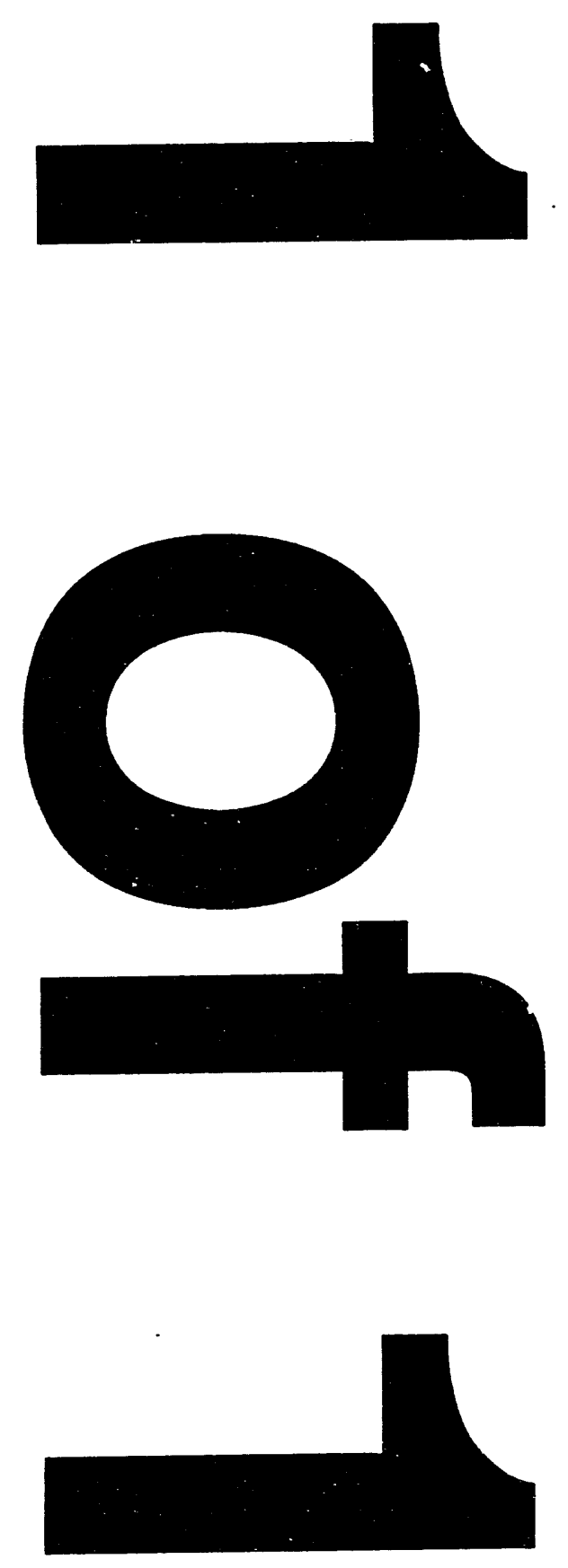


\section{Dual-Band Infrared (DBIR) Imaging Inspections of Boeing 737 and KC-135 Aircraft Panels}

\section{Prepared for}

P. K. Bhagat

Manager, Nondestructive Inspection R\&D

Aging Aircraft Program

FAA Technical Center

Atlantic City Airport, NJ 08505

by

N. K. Del Grande, K. W. Dolan, P. F. Durbin Nondestructive Evaluation Section

Engineering Sciences Division

M. R. Gorvad

Computer A-pplications' Sciences and Engineering Division

and A. B. Shapiro

Thermal-Fluids Group

Nuclear Test Engineering Division
RECEIVED

JAN 271994

OSTI

27 August 1993

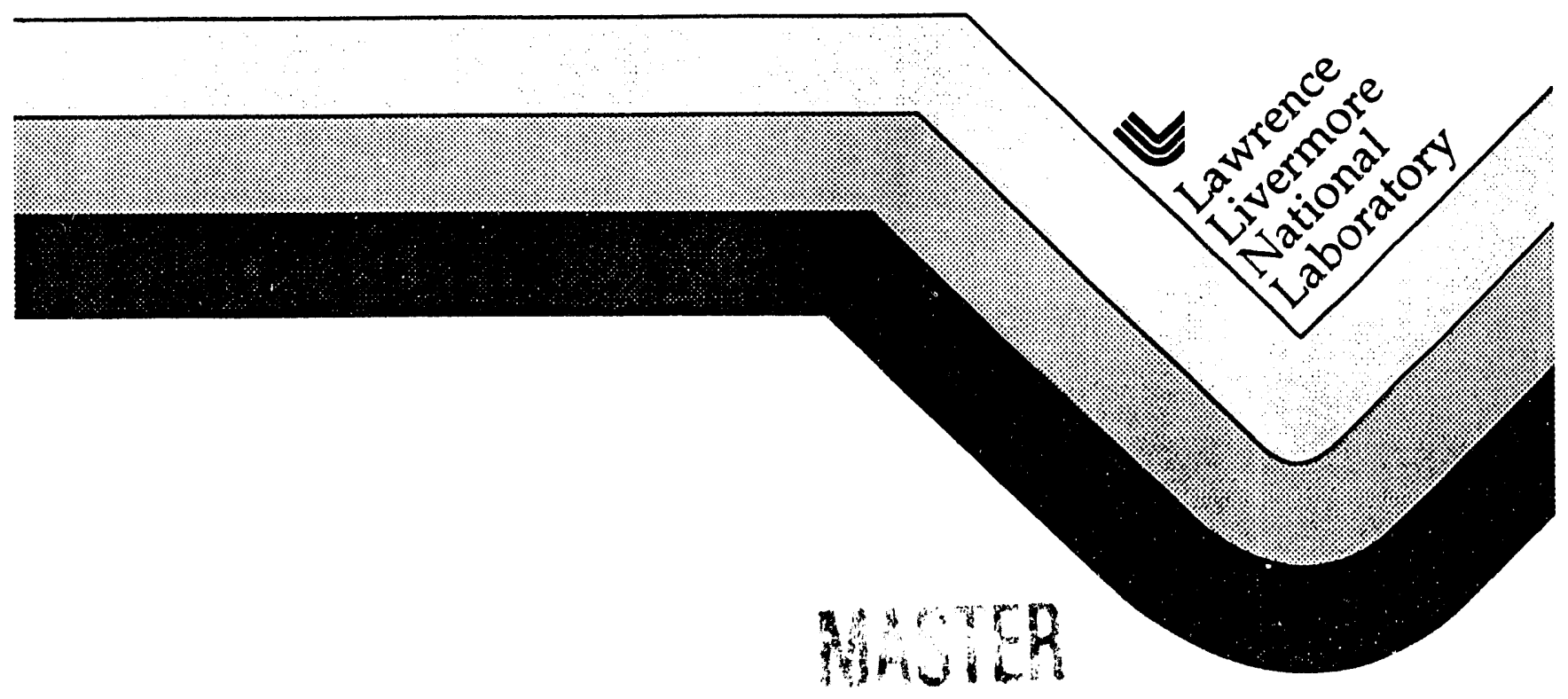




\section{DISCLAIMER}

This document was prepared as an account of work sponsored by an agency of the United States Government. Neither the United States Government nor the University of California nor any of their employees, makes any warranty, express or implied, or assumes any legal liability or responsibility for the accuracy, completeness, or usefulness of any information, apparatus, product, or process disclosed, or represents that its use would not infringe privately owned rights. Reference herein to any specific commercial products, process, or service by trade name, trademark, manufacturer, or otherwise, does not necessarily constitute or imply its endorsement, recommendation, or favoring by the United States Government or the University of California. The views and opinions of authors expressed herein do not necessarily state or reflect those of the United States Government or the University of California, and shall not be used for advertising or product endorsement purposes. 
TABLE OF CONTENTS

PAGE NO.

1.0 INTRODUCTION 3

2.0 POWER LAW MODEL ,

3.0 THERMAL RESPONSE TO HEAT FLASH , 4

4.0 EXPERIMENTAL EQUIPMENT, SETUP AND TEST PROCEDURE 6

5.0 DBIR RESULTS FOR BOEING 737 AND KC-135 AIRCRAFT PANELS 7

6.0 CHARACTERISTICS OF A BOEING 737 LAP JOINT DISBOND SITE 7

7.0 INTERPRETATION OF TEMPERATURE VERSUS TIME BEHAVIOR

8.0 FAA/AANC LIBRARY SAMPLES AND BOEING 737 AIRCRAFT: CORROSION TABLES

9.0 BOEING KC-135 AIRCRAFT PANELS: CORROSION TABLES 21

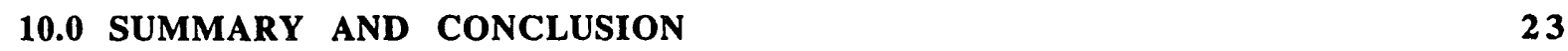

11.0 ACKNOWLEDGEMENTS $\quad 24$

12.0 REFERENCES 25

APPENDIX A: PHOTOGRAPHS OF HANGAR SETUP AND TEST PANELS 26

APPENDIX B: COLOR-CODED IMAGES OF BOEING 737 AND TEST PANELS 35

APPENDIX C: COLOR-CODED IMAGES OF BOEING KC-135 PANELS 48 


\title{
DUAL-BAND INFRARED (DBIR) IMAGING INSPECTIONS OF BOEING 737 AND KC-135 AIRCRAFT PANELS
}

\author{
N. K. Del Grande, K. W. Dolan, P. F. Durbin, M. R. Gorvad \\ and A. B. Shapiro \\ Lawrence Livermore National Laboratory \\ P. O. Box 808, Livermore CA 94550
}

\begin{abstract}
We apply dual-band infrared (DBIR) imaging as a dynamic thermal tomography tool for wide area inspection of a Boeing 737 aircraft, owned by the FAA at the Aging Aircraft NDI Development and Demonstration Center (AANC) at Sandia National Laboratories in Albuquerque, NM, and several Boeing KC-135 aircraft panels, used for the round robin experiment conducted at Tinker AFB, OK. Our analyses are discussed in this report. After flash-heating the aircraft skin, we record synchronized DBIR images every $40 \mathrm{~ms}$, from onset to 8 seconds after the heat flash. We analyze selective DBIR image ratios which enhance surface temperature contrast and remove surface-emissivity clutter (from dirt, dents, tape, markings, ink, sealants, uneven paint, paint stripper, exposed metal and roughness variations). The Boeing 737 and $\mathrm{KC}-135$ aircraft fuselage panels have varying percent thickness losses from corrosion. We established the correlation of percent thickness loss with surface temperature rise (above ambient) for a partially corroded F-18 wing box structure (with a $2.9 \mathrm{~mm}$ uncorroded thickness) and several aluminum reference panels (with 1.0,1.1, 2.3 and $3.9 \mathrm{~mm}$ thicknesses) which had 6 to $60 \%$ tt: ickness losses at milled flat-bottom hole sites. Based on this correlation, lap splice temperatures rise $1{ }^{\circ} \mathrm{C}$ per $24 \pm 5 \%$ material loss at $0.4 \mathrm{~s}$ after the heat flash. We show tables, charts and temperature maps of typical lap splice material losses for the riveted (and bonded) Boeing 737, and the riveted (but unbonded) Boeing KC-135. We map the fuselage composite thermal inertia, $(\mathrm{kpc})^{1 / 2}$, based on the (inverse) slope of the surface temperature versus inverse square root of time. Composite thermal inertia maps characterize shallow skin defects within the lap splice at early times $(<0.3 \mathrm{~s})$ and deeper skin defects within the lap splice at late times $(>0.4 \mathrm{~s})$. Late time composite thermal inertia maps depict where corrosion-related thickness losses occur (e.g., on the inside of the Boeing 737 lap splice, beneath the galley and the latrine). Lap splice sites on a typical Boeing KC-135 panel with low composite thermal inertia values had high skin-thickness losses from corrosion.
\end{abstract}

\subsection{INTRODUCTION}

Dual-band infrared (DBIR) imaging was pioneered by LLNL as a precise temperature survey technique to depict small temperature differences resulting from heat flow anomalies. Previous successful applications of DBIR imaging (from aircraft, helicopter, tower and raised platforms) detected underground and obscured object sites with $0.2^{\circ} \mathrm{C}$ or more surface temperature differences from:

- geothermal aquifers under 6 to 60 meters of dry soil 1,2

- cemetery walls, trenches and a building foundation under $80 \mathrm{~cm}$ of asphalt and debris 3

- buried mines, rocks and objects under 1 to $20 \mathrm{~cm}$ of disturbed sand, soil, or sod 3-8

- sea ice thicknesses varying from 5 to $50 \mathrm{~cm} .9,10$

This paper discusses the analysis of DBIR images to identify hidden defects within flash-heated test specimens and aircraft structures. We are developing a wide-area, non-contact, non-destructive inspection (NDI) tool to depict hidden defects within:

- adhesively-bonded aluminum lap joints with disbond (no-adhesive) sites replicating the skin of a Boeing 737 aircraft $9,11,12$ - an aged Boeing 737 aircraft (see Appendix A, Figs. A-1 and A-2) at Sandia National Laboratories in Albuquerque, NM

- calibration panels with milled flat-bottom holes replicating material losses for a corroded Boeing KC-135 aircraft lap splice

- a F-18 wing box structure from Northrop Corporation with measured material losses and by-products of corrosion

- several Boeing KC-135 aircraft panels dismantled after the round robin NDI experiments conducted at Tinker AFB, OK

Using judiciously selected DBIR image ratios (from cameras which record the infrared at 3-5 $\mu \mathrm{m}$ and 8-12 $\mu \mathrm{m}$ ) we enhance surface temperature contrast and remove the mask of surface emissivity cluter. By removing the clutter mask (from dirt, dents, tape, markings, ink, sealants, uneven paint, paint stripper, exposed metal and roughness variations) we clarify interpretation of surface temperature anomalies associated with hidden defect sites. The basis for this is described in the following section. 


\subsection{POWER LAW MODEL}

A power law model 13 explains how infrared signals vary as a function of the surface emissivity and the surface's absolute temperature:

$$
\mathbf{I} \lambda \sim \mathbf{e}_{\lambda} \mathbf{T}^{50 / \lambda}
$$

where $\mathbf{I}_{\lambda}$ is the intensity at a given wavelength, $\mathbf{e} \lambda$ is emissivity at that wavelength, $\mathbf{T}$ is in temperature in Kelvin and $\lambda$ is the wavelength in micrometers.

We can obtain temperature alone by computing the ratio

$$
\mathbf{R}=\frac{\mathbf{I}_{5}}{\mathbf{I}_{10}}=\frac{\mathbf{e}_{5} \mathbf{T}^{50 / 5}}{\mathbf{e}_{10} \mathbf{T}^{50 / 10}}=\frac{\mathbf{e}_{5}}{\mathbf{e}_{10}} \mathbf{T}^{5},
$$

For a greybody, $\mathbf{e}_{5}=\mathbf{e}_{10}$ and $\mathbf{R} \sim \mathbf{T}^{5}$.

We can obtain the emissivity ratio by computing

$$
\frac{\left(\mathbf{I}_{10}\right)^{2}}{\mathbf{I}_{5}}=\frac{\left(\mathbf{e}_{10}\right)^{2\left(\mathbf{T}^{5) 2}\right.}}{\mathbf{e}_{5} \mathbf{T}^{10}}=\frac{\left(\mathbf{e}_{10}\right)^{2}}{\mathbf{e}_{5}}
$$

This ratio is sensitive mostly to surface objects which have very different emissivities at 5 and 10 micrometers (most metal surfaces). We then compute the normalized ratios to obtain temperature and emissivity-ratio (E-ratio) maps:

$$
\left(\mathbf{T} / \mathbf{T}_{\mathrm{av}}\right)^{\mathbf{5}}=\left(\mathrm{S} / \mathrm{S}_{\mathrm{av}}\right) /\left(\mathbf{L} / \mathbf{L}_{\mathrm{av}}\right) \text { and } \mathbf{E} \text {-ratio }=\left(\mathbf{L} / \mathbf{L}_{\mathrm{av}}\right)^{2} /\left(\mathrm{S} / \mathrm{S}_{\mathrm{av}}\right)
$$

where $S$ is the short-wavelength intensity (e.g., $\mathbf{I}_{5}$ ), $S_{a v}$ is the average value of the pixels in $S, L$ is the long wavelength intensity (e.g., $\mathbf{I}_{10}$ ) and $\mathbf{L}_{\mathrm{av}}$ is the average value of the pixels in $\mathbf{L}$.

\subsection{THERMAL RESPONSE TO HEAT FLASH}

To describe the results of our aircraft measurements, we refer to the heat diffusion equation, which is:

$$
\rho c \frac{\partial T}{\partial t}=k \nabla^{2} T
$$

The solution of (EQ 5) for a semi-infinite solid with an instantaneous surface heat flux is: 14

$$
T(x, t)=\frac{q}{\sqrt{4 \pi k \rho c t}} \exp \left(-\frac{x^{2}}{4 \alpha t}\right)
$$

where $\mathrm{T}$ is temperature, $\mathrm{x}$ is the distance from surface, $\mathrm{k}$ is thermal conductivity, $\rho$ is density, $\mathrm{c}$ is heat capacity, $\alpha$ is thermal diffusivity, $t$ is time and $q$ is the surface heat flux. The solution of (EQ 6) at several depths as a function of time is shown graphically in Fig. 1. The semi-infinite solid approximation, where the surface temperature is proportional to the inverse square root of time describes our measured results for the KC-135 aircraft panels which had measured thicknesses, over the lap splices (including lap, doubler, stringer and patch thicknesses), varying from 4.2 to $7.5 \mathrm{~mm}$. We consider only the effects of corrosion which occur within lap splice structures for this report. 
There are two steps in solving the problem of heat transfer for thinner aircraft skins, apart from the lap splice structures considered in this report. First, during flash lamp heating, the solution to (EQ 5) for an insulated surface at $x=0$ and flux $F$ applied to the surface at $x=l$ is

$$
T=\frac{F t}{\rho c l}+\frac{F l}{k}\left\{\frac{3 x^{2}-l^{2}}{6 l^{2}}-\frac{2}{\pi^{2}} \sum_{n=1}^{\infty} \frac{(-1)^{n}}{n^{2}} \exp \left(\frac{-\alpha n^{2} \pi^{2} t}{l^{2}}\right) \cos \left(\frac{n \pi x}{l}\right)\right\}
$$

Secondly, there is heat redistribution in the slab. The solution of (EQ 5) when the slab has an initial temperature distribution of $f(x)$, calculated from (EQ 7) at the end of the flash lamp heating, and with both surfaces insulated is

$$
T=\frac{1}{l} \int_{0}^{l} f(x) d x+\frac{2}{l} \sum_{n=1}^{\infty} \exp \left(\frac{-\alpha n^{2} \pi^{2} t}{l^{2}}\right) \cos \left(\frac{n \pi x}{l}\right) \int_{0}^{l} f(x) \cos \left(\frac{n \pi x}{l}\right) d x
$$

Heat loss by convection has been omitted. This is justified over the short time scale of this problem because the thermal conduction conductance (conductance due to heat loss by conduction) is $240,000 \mathrm{~W} / \mathrm{m}^{2} \mathrm{sec}$, while the conductance due to heat loss by convection is only $5 \mathrm{~W} / \mathrm{m}^{2} \mathrm{sec}$. Testing the validity of these analytical solutions and reporting our results is beyond the scope of this paper. Apart from the thicker lap splice areas, covered in this paper, there are other areas with thinner (1.5 $\mathrm{mm}$ single thickness) aircraft skins.

This problem was modeled using TOPAZ2D. ${ }^{15}$ Parameters chosen were:

- heat lamp surface flux $F=1.510^{6} \mathrm{~W} / \mathrm{m}^{2}$ for $0.004 \mathrm{sec}$

- slab thickness $l=0.001 \mathrm{~m}$

- aluminum $\rho=2700 \mathrm{Kg} / \mathrm{m}^{3}, k=240 \mathrm{~W} / \mathrm{m} \mathrm{sec}, c=920 \mathrm{~J} / \mathrm{KgC}$

- aluminum oxide $p=1200 \mathrm{Kg} / \mathrm{m}^{3}, k=25 \mathrm{~W} / \mathrm{m} \mathrm{sec}, c=780 \mathrm{~J} / \mathrm{KgC}$

Temperature histories at several depth locations [(a) $x=0$, (b) $x=0.25 \mathrm{~mm}$, (c) $x=0.50 \mathrm{~mm}$, (d) $x=0.75 \mathrm{~mm}$, (e) $x=1.00 \mathrm{~mm}$ ] are shown in Figures 2 and 3. Figure 2 is the time response for a $1.00 \mathrm{~mm}$ thick aluminum slab. Figure 3 is the time response for a composite slab consisting of aluminum $(0.9 \mathrm{~mm})$ with a corrosion layer $(0.1 \mathrm{~mm})$ of aluminum oxide.

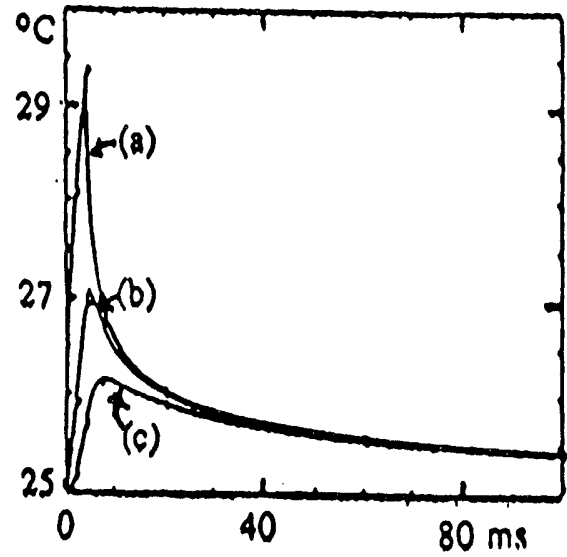

Figure \& The lemperalure.lime response of (Eq. 6) Por a somi. infinite aluminum slab ai the surface (a) and at depthe of 0.50 $\mathrm{mm}(\mathrm{O})$ and $1.0 \mathrm{~min}(\mathrm{c})$.

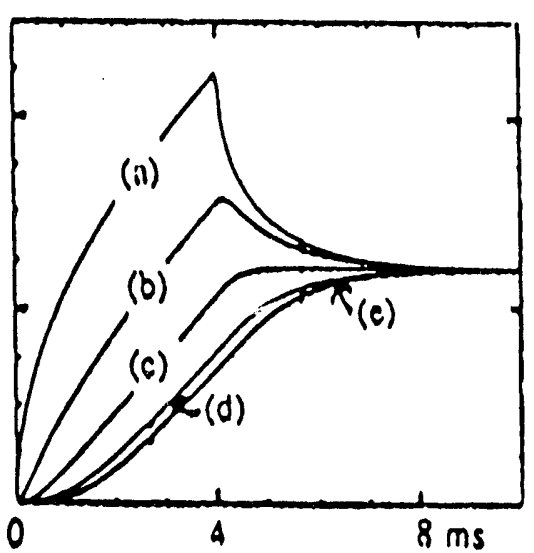

Figure 2. The cemperalure-lime response for $1 \mathrm{~mm}$ ihick aluminum slab al depihs of $x=0$ $\mathrm{mm}(\mathrm{a}), x=0.25 \mathrm{~mm}(\mathrm{~b}), x=0.51)$ $\mathrm{mm}(\mathrm{c}), x=0.75 \mathrm{~mm}(\mathrm{~d}), x=1.0$ $\mathrm{mm}(c)$.

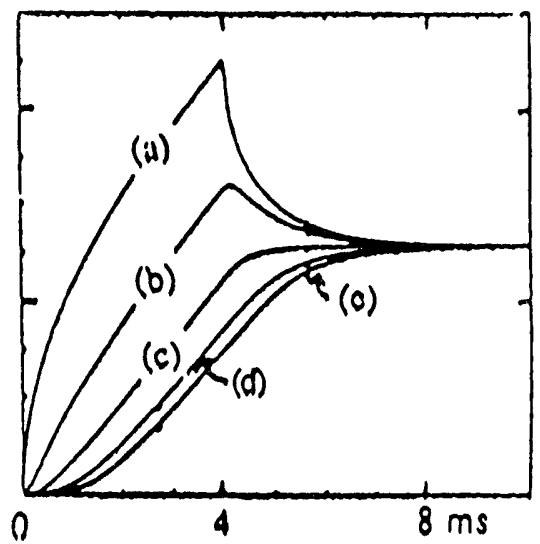

Figure 3. The lemperalure lime response for a $1 \mathrm{~mm}$ inick slab of aluminum $(0.9 \mathrm{~mm})$ and aluminum oxide $(0.1 \mathrm{~mm})$ al depiths of $x=0$ $\mathrm{mm}(\mathrm{a}), x=0.25 \mathrm{~mm}(\mathrm{~b}), x=0.50$ $\mathrm{mm}(c), x=0.75 \mathrm{~mm}(d), x=1.0$ $\mathrm{mm}(\mathrm{c})$. 


\subsection{EXPERIMENTAL EQUIPMENT, SETUP AND TEST PROCEDURE}

\subsection{Experimental equipment}

The following equipment was used for the demonstration of DBIR imaging as a dynamic thermal tomography tool for nondestructive inspection (NDI) of the FAA Bocing 737 aircraft at the Sandia National Laboratory hangar in Albuquerque, NM. Similar equipment was used to inspect the Boeing KC-135 panels, which were dismounted from the Tinker AFB aircraft in Oklahoma and transponed to the Lawrence Livermore National Laboratory in Livermore, CA.

- Infrared imager - Agema 880 dual band Burst Recording Unit (BRU) with the 3-5 micron and 8-12 micron DBIR scanners, a 12 bit digital image processor and a 1.3 Gbyte hard drive.

- Color printer - Mitsubishi CP210.

- Flash lamps - 3 Norman 4000 Joule and 1 Balcor 6000 Joule lamps, LLNL flash lamp control box, and LLNL adjustable flash lamp/scanner positioning stand.

- Image processing workstation - Silicon Graphics Indigo R-3000 with 2-1.2 Gbyte Hard drives and 48 Mbytes of memory.

- Visual images - $35 \mathrm{~mm}$ (still) and $8 \mathrm{~mm}$ (video) cameras.

\subsection{Experimental setup}

For effective nondestructive inspection of highly reflective (unpainted) aluminum panels, we prepare the target surface to increase the thermal gain from the flash lamps. This gain increase provides the temperature contrast needed to resolve subtle differences which distinguish hidden defects within aircraft lap splice structures from background noise. To this end, we spray paint the area of interest on the aircraft skin using Crayola black (water removable) paint. Portable (welding) shields isolate the flash lamps from the operator or other personnel in the area, thereby providing a safe working environment.

The dual-band (Agema 880) infrared scanners are mounted on a positioning stand and co-aligned to image the same field of view at. a distance of 26 inches from the test panel. Four flash lamps are positioned 16 inches from the panel and angled to provide uniform heating. The flash lamps are arranged in a square array (24 inches on a sidc). They are connected to the flash lamp control box and to the Agema computer. The operator presses a firing button. This triggers the flash lamps and synchronizes the timing to start a data capture sequence $2.8 \mathrm{~ms}$ after the lamps fire. A typical sequence is 50 frames. Each frame has a duration of $160 \mathrm{~ms}$. A frame consists of 4 interlaced fields, each with a duration of $40 \mathrm{~ms}$. Thus we view on a display screen, record, and subsequently store on the hard drive, 200 consecutive ( $40 \mathrm{~ms}$ duration) DBIR images during the 8 seconds following a $4.2 \mathrm{~ms}$ heat flash.

The recently modified FAA/LiNL prototype DBIR system (by Bales Scientific Inc.) includes a continuous line scan capability to time-resolve thermal images from 0 to $400 \mathrm{~ms}$ after onset of the flash, in intervals of $550 \mu \mathrm{s}$. This will be used to test the predictability of TOPAZ-2D surface temperature calculations (see Figures 2 and 3).

\subsection{Experimental procedure}

The scanners and lamps are set up as described above. A typical field of view is $28 \mathrm{~cm}$ (11 inches). Video camcorders are used to document all areas of interest, whereas $35 \mathrm{~mm}$ cameras provide still photographs for special areas of interest. The computer data files are named using the aircraft stringer and frame position numbers. A written log is kept of file names and setup parameters. Small reference squares are taped to the aircraft skin to mark the top center of each IR image. Lap splice sites along the aircraft stringers under inspection are flash heated. The 50 frame (200 field) sequences are recorded at a data capture rate of 25 fields per second. The recorded digital data are verified, the set up shifted to the next position, and the sequence repeated.

The data on the hard disk is backed up on 1/4 inch streamer tape, transferred to the Silicon Graphics workstation via an ether net connection and backed up on tape from the work station. Initial data analyses were conducted with the Agema software which provided color-coded temperature maps as output from the color printer. Specialized LLNL software codes (which run on the SGI work station) provide enhanced temperature contrast maps, emissivity-ratio maps, thermal inertia maps, dynamic thermal response curves and additional information. 


\subsection{DBIR RESULTS FOR THE BOEING 737 AND KC.135 AIRCRAFT PANELS}

To clarify interpretation, it is important to distinguish between surface (or near surface) clutter and heat transfer anomalies at potential sites which identify hidden aircraft defects. To this end, we applied DBIR analyses. We produced (enhanced contrast, $\mathrm{T}^{5}$ ) temperature and emissivity-ratio maps for the Tinker AFB Boeing KC-135, End Panels No 1LF (Figure 4) and No. 5IRR (Figure 5). Also, we produced $\left(\mathrm{T}^{5}\right)$ temperature and emissivity-ratio maps for the FAA/AANC Boeing 737 aircraft fuselage (Figure 6) and a previously characterized lap joint specimen, ${ }^{12}$ designed to replicate the Boeing 737 aircraft skin, belonging to the AANC Library (Figures 7-9). Figures 4-6 and Figure 9 show (left to right) the two apparent temperature maps (recorded at $10 \mu \mathrm{m}$ and at $5 \mu \mathrm{m}$ ), the enhanced contrast temperature map, which varies as $\mathrm{T}^{5}$, and the emissivity-ratio map based on (EQ 2), (EQ 3) and (EQ 4).

Various types of clutter are shown in Figures 4-6 and Figure 9. In Figure 4, we see wax pencil markings (upper left corner) as red (hot) on the temperature maps, but indistinguishable on the emissivity-ratio map, since the surface was painted black. In Figure 5, we use the three temperature-related maps to explain a hot "bandaid-like" patched corrosion area (center, left) and the emissivity-ratio map to explain the roughness effect of masking tape which covered the heavily corroded area. In Figure 6, we note temperature and emissivity-ratio differences for various black cloth (red, hot) and metal (purple, cold) tape markers at the top, right of center, and the masking tape marker (painted black) at the top right corner. Also, we note from the emissivity. ratio map where the biack paint was not applied uniformly (e.g., at the bottom of the fuselage, beneath the lap splice). Wc note from emissivity-ratio images in Figure 9 that the front-surface black paint was applied uniformly in (d).

\subsection{CHARACTERISTICS OF A BOEING 737 LAP JOINT DISBOND SITE}

The Boeing 737 lap joint specimen 12 in Figure 7 has a rectangular $(0.1 \mathrm{~mm}$ thick) air layer (with no epoxy) shown at the center of the diagram in (a) which replicates a disbond sitc. The $10 \mu \mathrm{m}$ IR image shows the disbond site as 0.4 or $0.5^{\circ} \mathrm{C}$ warmer (where it was flash heated) than the epoxy-glue sites which surround it in (b). The ultrasound image shows a belter bond quality at decreasing values for the epoxy-glue sites in (c). The reverse geometry $x$ rays at $100 \mathrm{keV}$ scatter differently through two overlapping ( $0.9 \mathrm{~mm}$ thick) aluminum sheets with a $0.1 \mathrm{~mm}$ air gap than through the same two sheets with an equally thick epoxy-glue layer in (d).

In Figure 8, we see the warmer than ambient, flash-heated, front-surface disbond sitc temperatures at $0.5,2.0,4.0$ and $8.0 \mathrm{~s}$ after the flash (taken at $10 \mu \mathrm{m}$ in top row images: a, b, c, d) and corresponding cooler than ambient, simultaneously recorded back-surface disbond site temperatures (taken at $5 \mu \mathrm{m}$ in bottom row images: e, f, g, h). For symmetric lap joint disbonds, the front-surface disbond site pattern is rectangular, whereas the back-surface disbond site pattern is circular. At $0.5 \mathrm{~s}$, much of the heat transfer is two dimensional, across the lap to the back side in the transverse direction (parallel to the surface).

\subsection{INTERPRETATION OF TEMPERATURE VERSUS TIME BEHAVIOR}

Temperature variations with time (after the heat flash) are compared for the Boeing 737 Stringer 26, Station 400 (s26r400.7) in Figure 10 and the Boeing KC-135 Panel 2 (2FR, at the right edge of the 30 inch panel) in Figure 11 . We note the $2^{\circ} \mathrm{C}$ range at $0.04 \mathrm{~s}, 0.40 \mathrm{~s}, 0.80 \mathrm{~s}$ (top row, left to right) and at $1.60 \mathrm{~s}, 3.20 \mathrm{~s}$ and $6.40 \mathrm{~s}$ (bottom row, left to right), emphasizes dynamic thermal contrast differences between the Boeing 737 and the Boeing KC-135 at (warm, red) lap joint defect sites.

Corrosion within the Boeing 737 (epoxy-bonded) lap splice causes disbonding. Disbonding allows air to be trapped. Trapped air acts like an insulator. It does not allow heat to transfer longitudinally (perpendicular to the front face) by conduction from the front to the back surface (at late times $0.5 \mathrm{~s}$ or more after the flash) as readily as it would without trapped air. This effect is shown in Figure 10 by the near-constant temperature contrast from 0.4 to $1.6 \mathrm{~s}$ which is based on our measurements of the FAA/AANC owned Boeing 737. At late times, after 0.4 seconds, the (unbonded) Boeing KC-135 lap splice has a different temperature versus time response than the (bonded) Boeing 737 lap splice because it does not have adhesive bonding to mask the correlation between the percentage material loss and the corresponding surface temperature rise associated with corrosion.

To clarify interpretation of material loss effects related to corrosion (for both bonded and unbonded lap joints) we analyzed images taken at 0.4 seconds after the heat flash. This time was responsive to material loss from corrosion within the lap joint. It was late enough to be insensitive to timing uncertainties (from synchronizing the flash lamp with the images recorded at two IR bands) and surface clutter. It was early enough to provide a good temperature contrast for sites with and without material loss from corrosion. The $0.4 \mathrm{~s}$ measurements were effective regardless of trapped air which at later times masked the temperature-time history which characterized material-loss effects differently for disbonded sites (surrounded by bonded sites) than for unbonded sites (surrounded by unbonded sites). 


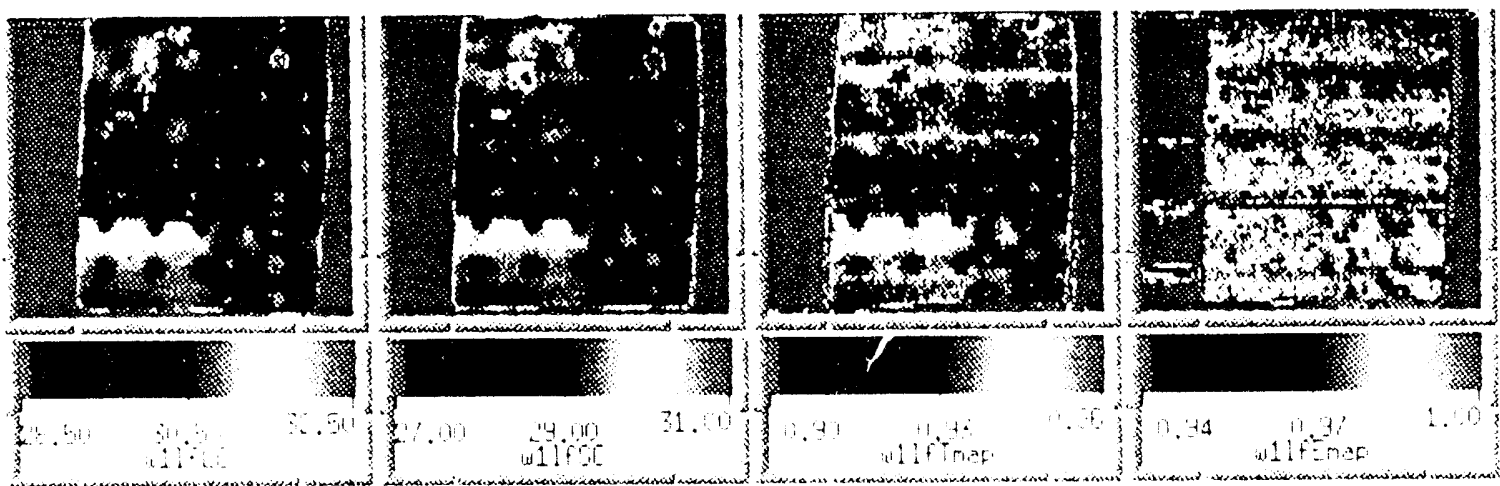

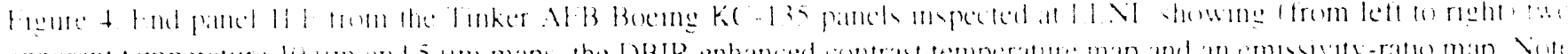

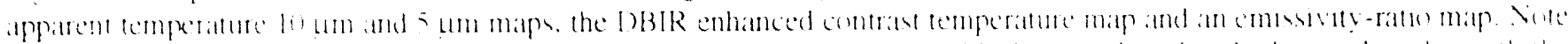

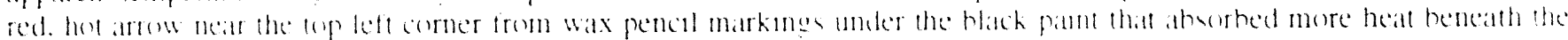

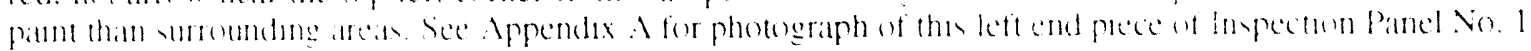
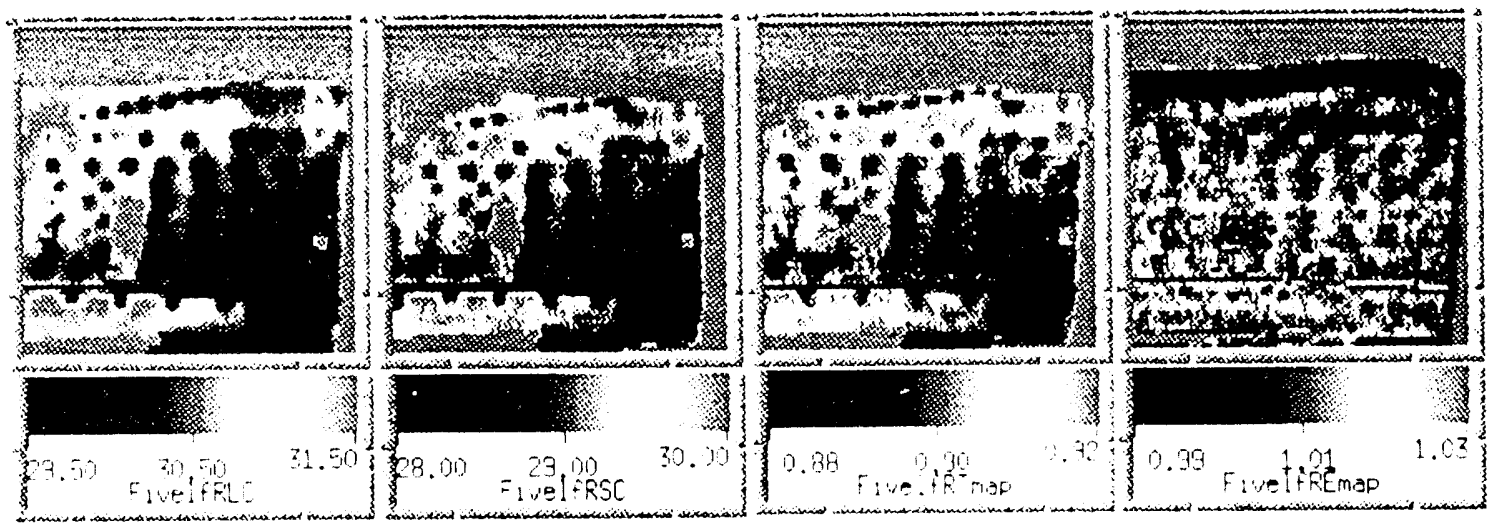

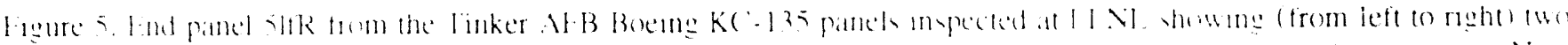

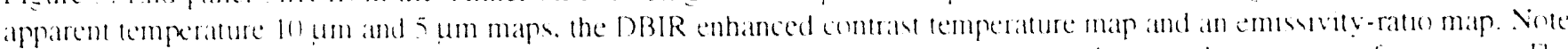

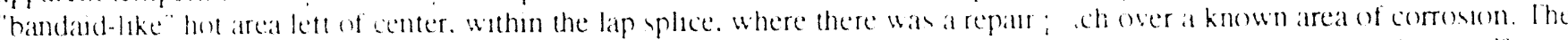

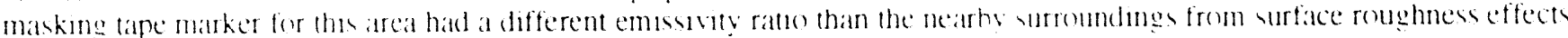
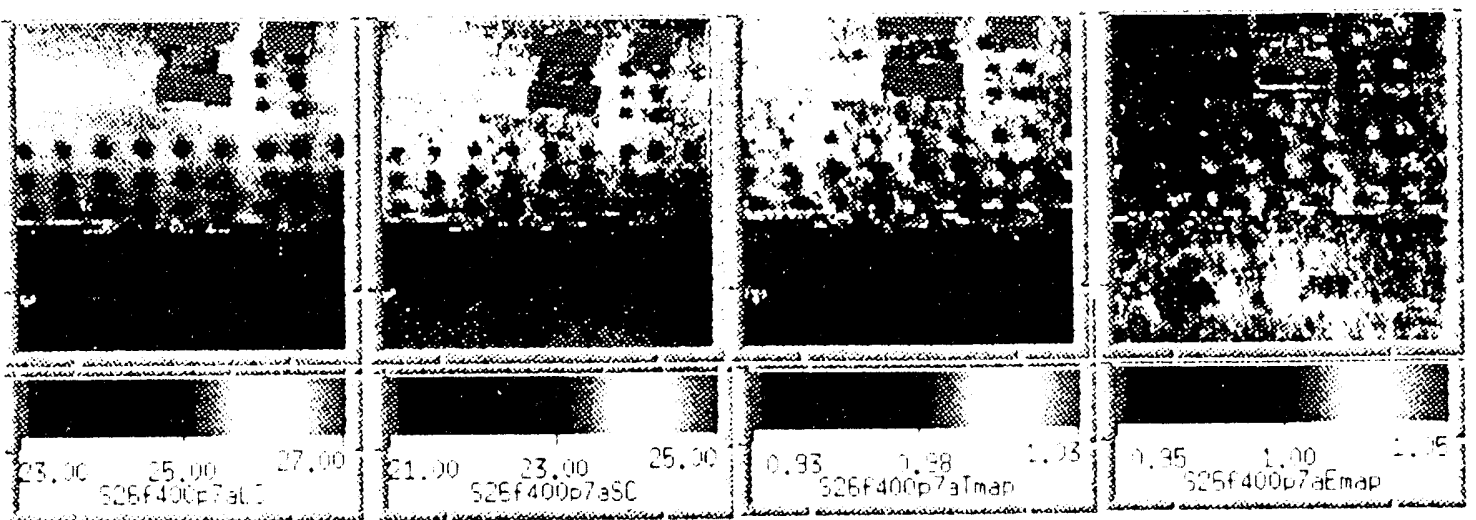

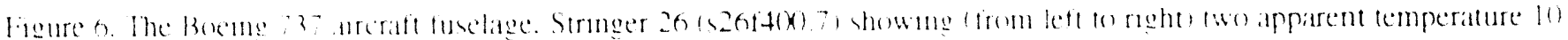

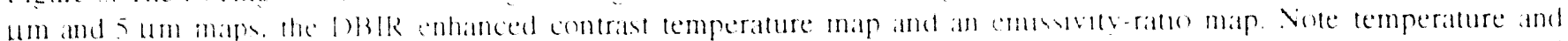

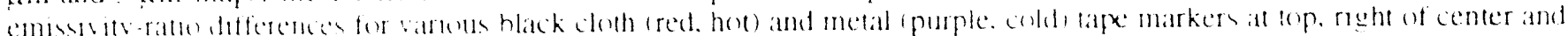

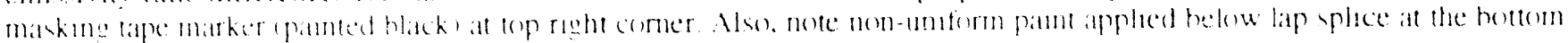




\subsection{DBIR RESULTS FOR THE BOEING 737 AND KC-135 AIRCRAFT PANELS}

To clarify interpretation, it is important to distinguish between surface (or near surface) clutter and heat transfer anomalies at potential sites which identify hidden aircraft defects. To this end, we applied DBIR analyses. We produced (enhanced contrast, $\mathrm{T}^{5}$ ) temperature and emissivity-ratio maps for the Tinker AFB Boeing KC-135, End Panels No 1LF (Figure 4) and No. SIrR (Figure 5). Also, we produced $\left(\mathrm{T}^{5}\right)$ temperature and emissivity-ratio maps for the FAA/AANC Boeing 737 aircraft fuselage (Figure 6) and a previously characterized lap joint specimen, 12 designed to replicate the Boeing 737 aircraft skin, belonging to the AANC Library (Figures 7-9). Figures 4-6 and Figure 9 show (left to right) the two apparent temperature maps (recorded at $10 \mu \mathrm{m}$ and at $5 \mu \mathrm{m}$ ), the enhanced contrast temperature map, which varies as $\mathrm{T}^{5}$, and the emissivity-ratio map based on (EQ 2), (EQ 3) and (EQ 4).

Various types of clutter are shown in Figures 4-6 and Figure 9. In Figure 4, we see wax pencil markings (upper left corner) as red (hot) on the temperature maps, but indistinguishable on the emissivity-ratio map, since the surface was painted black. In Figure 5, we use the three temperature-related maps to explain a hot "bandaid-like" patched corrosion area (center, left) and the emissivity-ratio map to explain the roughness effect of masking tape which covered the heavily corroded area. In Figure 6, we note temperature and emissivity-ratio differences for various black cloth (red, hot) and metal (purple, cold) tape markers at the top, right of center, and the masking tape marker (painted black) at the top right corner. Also, we note from the emissivityratio map where the black paint was not applied uniformly (e.g., at the bottom of the fuselage, beneath the lap splice). Wc note from emissivity-ratio images in Figure 9 that the front-surface black paint was applied uniformly in (d).

\subsection{CHARACTERISTICS OF A BOEING 737 LAP ? OINT DISBOND SITE}

The Boeing 737 lap joint specimen 12 in Figure 7 has a rectangular $(0.1 \mathrm{~mm}$ thick) air layer (with no epoxy) shown at the center of the diagram in (a) which replicates a disbond sitc. The $10 \mu \mathrm{m}$ IR image shows the disbond site as 0.4 or $0.5^{\circ} \mathrm{C}$ warmer (where it was flash heated) than the epoxy-glue sites which surround it in (b). The ultrasound image shows a better bond quality at decreasing values for the epoxy-glue sites in (c). The reverse geometry $x$ rays at $100 \mathrm{keV}$ scatter differently through two overlapping ( $0.9 \mathrm{~mm}$ thick) aluminum sheets with a $0.1 \mathrm{~mm}$ air gap than through the same two sheets with an equally thick epoxy-glue layer in (d).

In Figure 8, we see the warmer than ambient, flash-heated, front-surface disbond sitc temperatures at $0.5,2.0,4.0$ and $8.0 \mathrm{~s}$ after the flash (taken at $10 \mu \mathrm{m}$ in top row images: a, b, c, d) and corresponding cooler than ambient, simultaneously recorded back-surface disbond site temperatures (taken at $5 \mu \mathrm{m}$ in bottom row images: e, f, g, h). For symmetric lap joint disbonds. the front-surface disbond site pattern is rectangular, whereas the back-surface disbond site pattern is circular. At $0.5 \mathrm{~s}$, much of the heat transfer is two dimensional, across the lap to the back side in the transverse direction (parallel to the surface).

\subsection{INTERPRETATION OF TEMPERATURE VERSUS TIME BEHAVIOR}

Temperature variations with time (after the heat flash) are compared for the Boeing 737 Stringer 26, Station 400 (s26f400.7) in Figure 10 and the Boeing KC-135 Panel 2 (2FR, at the right edge of the 30 inch panel) in Figure 11 . We note the $2^{\circ} \mathrm{C}$ range at $0.04 \mathrm{~s}, 0.40 \mathrm{~s}, 0.80 \mathrm{~s}$ (top row, left to right) and at $1.60 \mathrm{~s}, 3.20 \mathrm{~s}$ and $6.40 \mathrm{~s}$ (bottom row, left to right), emphasizes dynamic thermal contrast differences between the Boeing 737 and the Boeing KC-135 at (warm, red) lap joint defect sites.

Corrosion within the Boeing 737 (epoxy-bonded) lap splice causes disbonding. Disbonding allows air to be trapped. Trapped air acts like an insulator. It does not allow heat to transfer longitudinally (perpendicular to the front face) by conduction from the front to the back surface (at late times $0.5 \mathrm{~s}$ or more after the flash) as readily as it would without trapped air. This effect is shown in Figure 10 by the near-constant temperature contrast from 0.4 to $1.6 \mathrm{~s}$ which is based on our measurements of the FAAVAANC owned Boeing 737. At late times, after 0.4 seconds, the (unbonded) Boeing KC-135 lap splice has a different temperature versus time response than the (bonded) Boeing 737 lap splice because it does not have adhesive bonding to mask the correlation between the percentage material loss and the corresponding surface temperature rise associated with corrosion.

To clarify interpretation of material loss effects related to corrosion (for both bonded and unbonded lap joints) we analyzed images taken at 0.4 seconds after the heat flash. This time was responsive to material loss from corrosion within the lap joint. It was late enough to be insensitive to timing uncertainties (from synchronizing the flash lamp with the images recorded at two IR bands) and surface clutter. It was early enough to provide a good temperature contrast for șites with and without material loss from corrosion. The $0.4 \mathrm{~s}$ measurements were effective regardless of trapped air which at later times masked the temperature-time history which characterized material-loss effects differently for disbonded sites (surrounded by bonded sites) than for unbonded sites (surrounded by unbonded siles). 


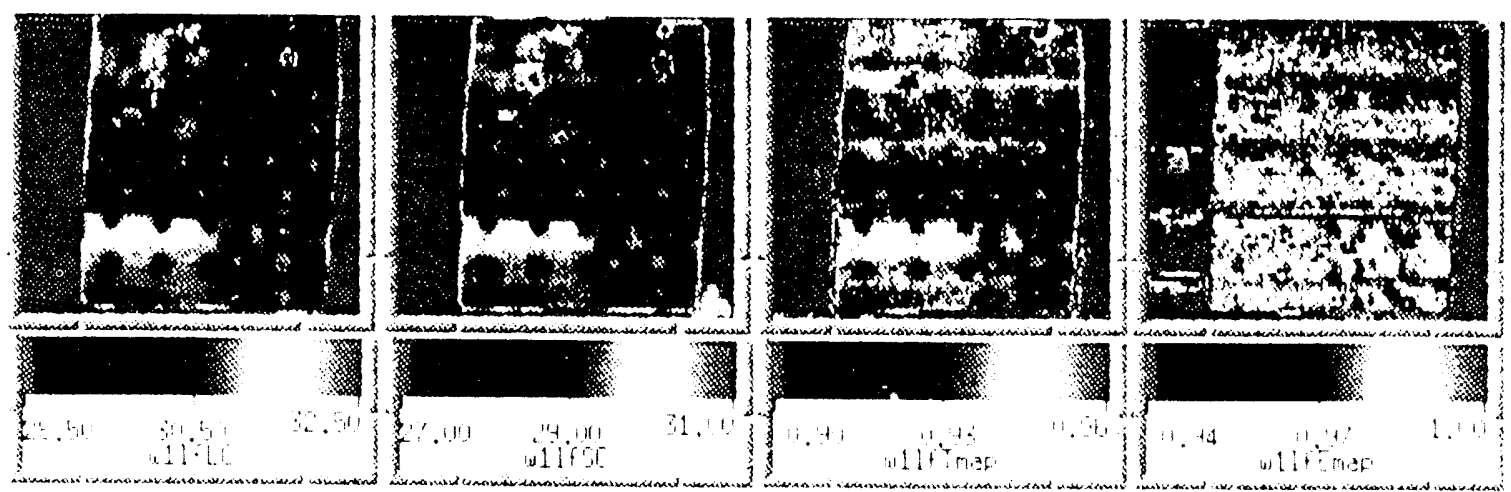

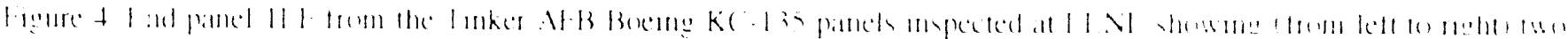

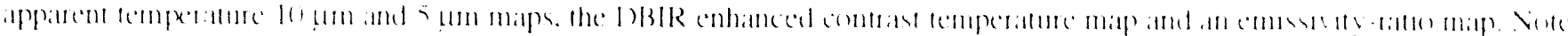

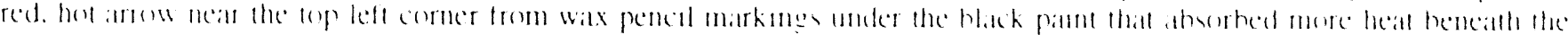

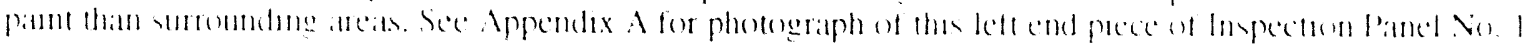
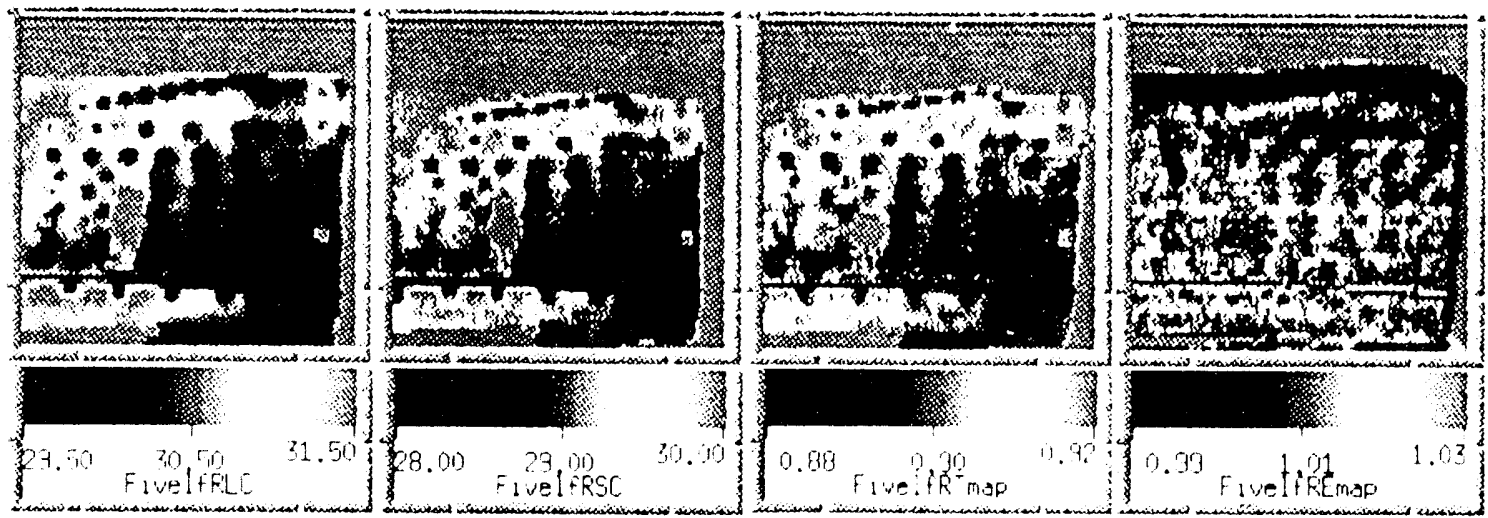

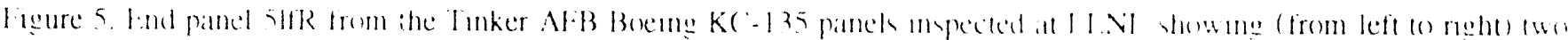

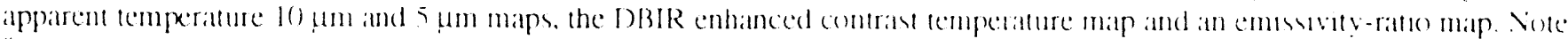
"bandaud-like" hot area left of center. withon the lap splice, where there was at repant patch over a known areat of corrosun. The

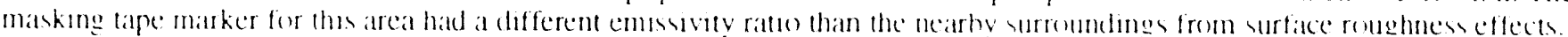
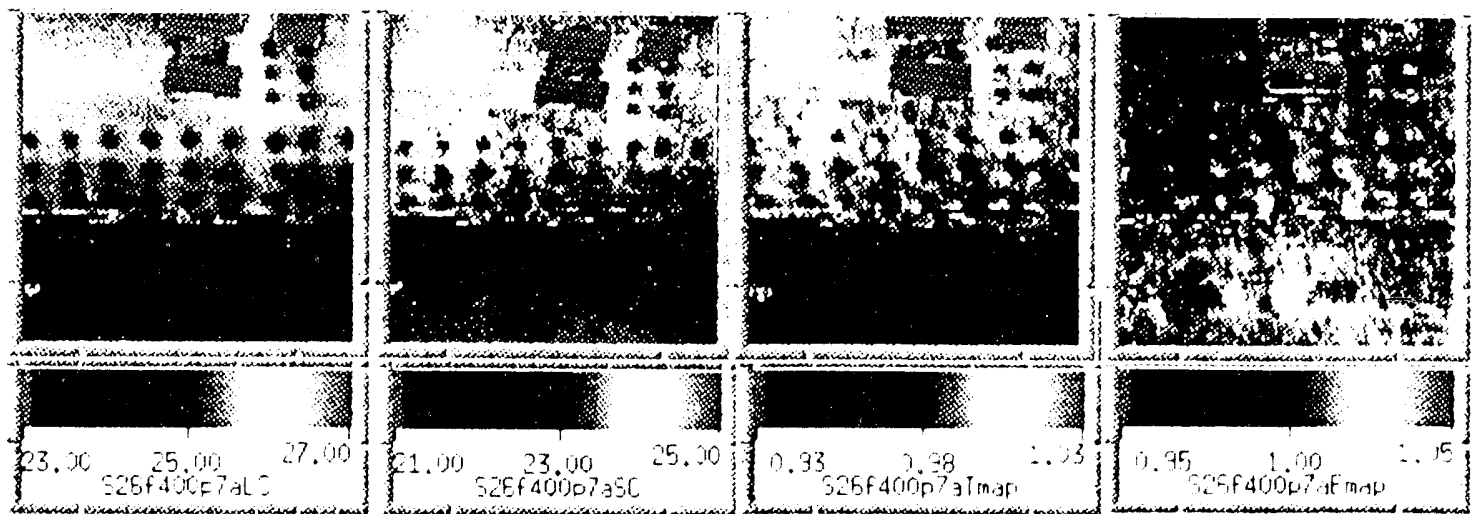

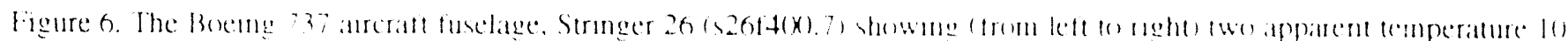

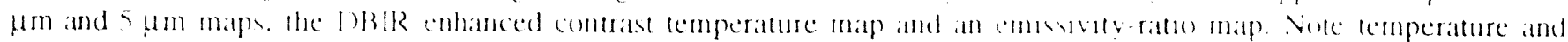

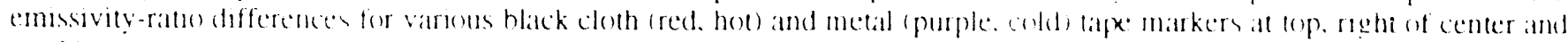

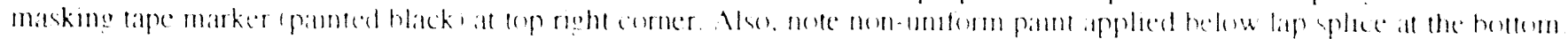


(a) $5.0 \quad-$

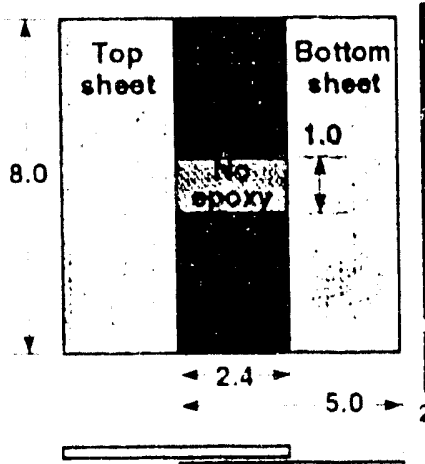

Epoxy adhesive layer

(0.004 to 0.005 inch thick) (b)

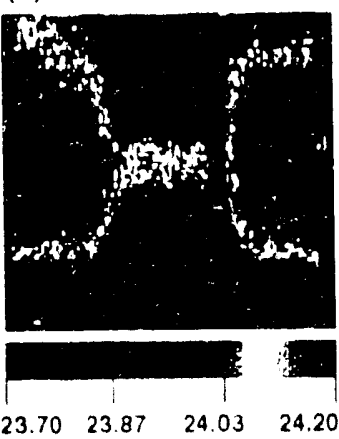

(c)

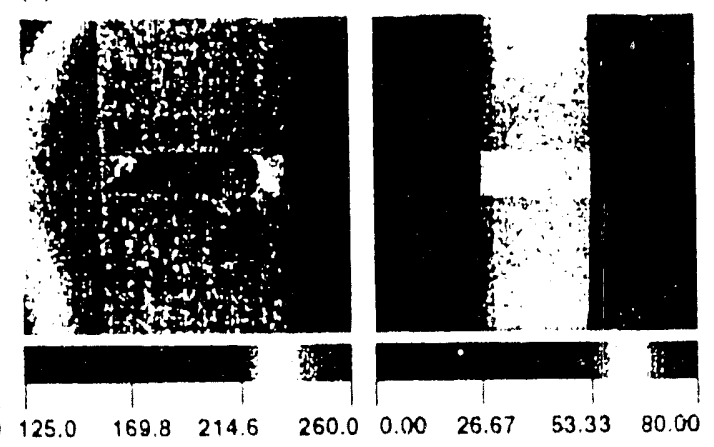

Figure ?
(a) Lap-joint
(b) Infrared
(c) Ultrasound
(d) X-ray

(a) $0.5 \operatorname{seconde}$
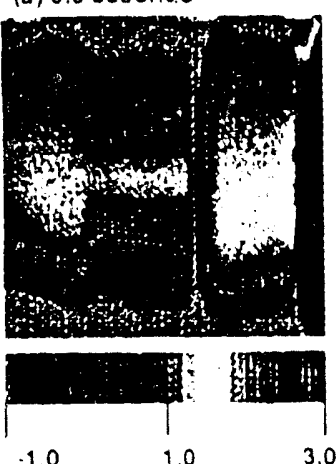

(e) 0.5 seconde
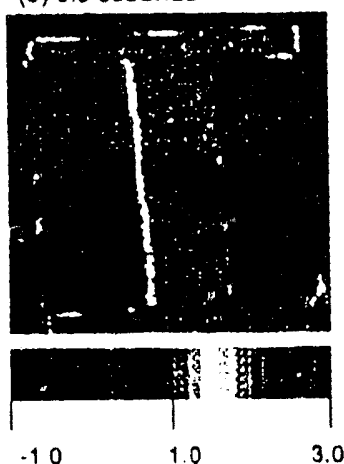

$-10$

(a)
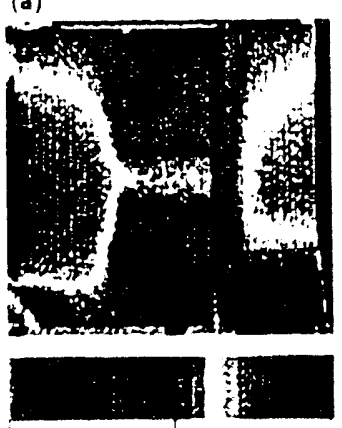

270

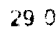

310

(b)

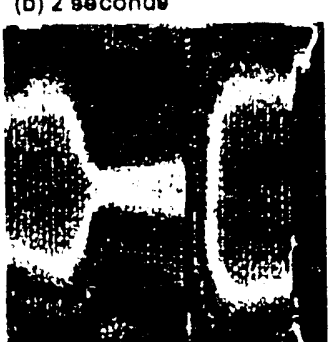

(c) 4 seconds
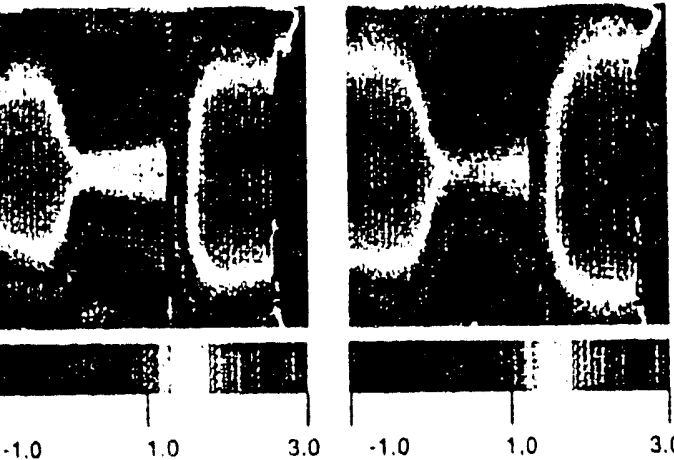

(f) 2 seconds
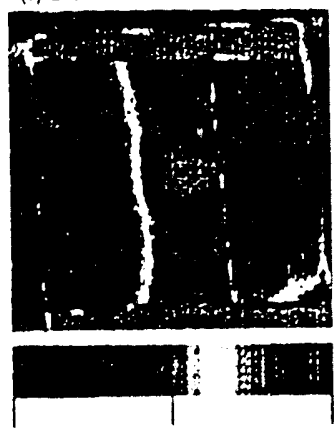

$-1.0$
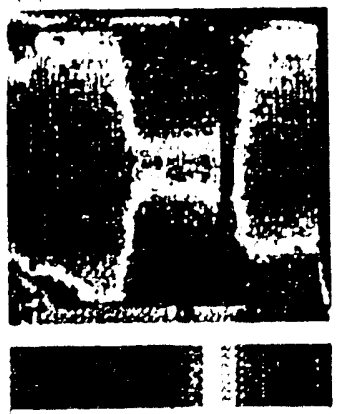

25.0 (g) 4 seconde
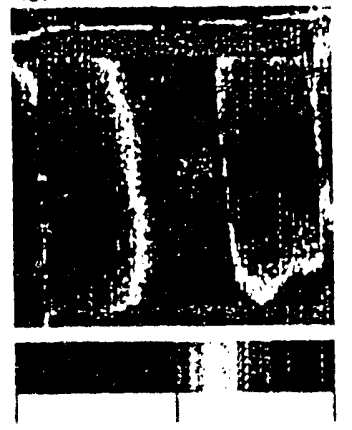

.1 .0

(c)
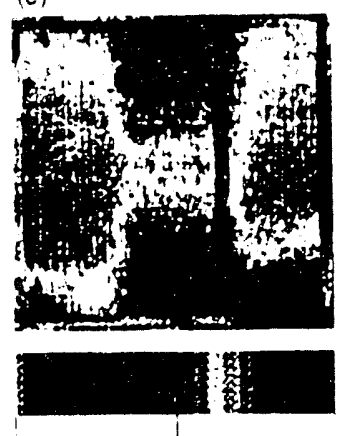

0.94 (d) 8 eeconds
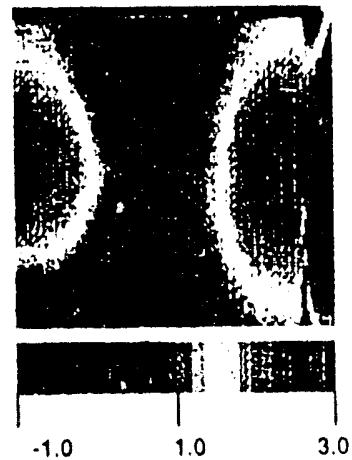

(h) 8 eoconds

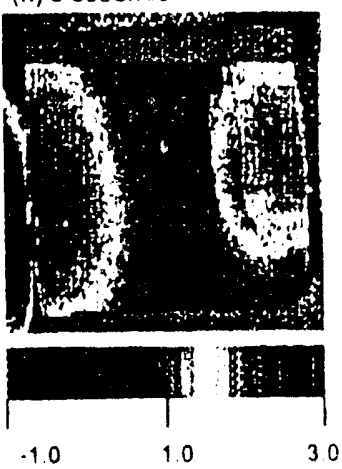

(d)
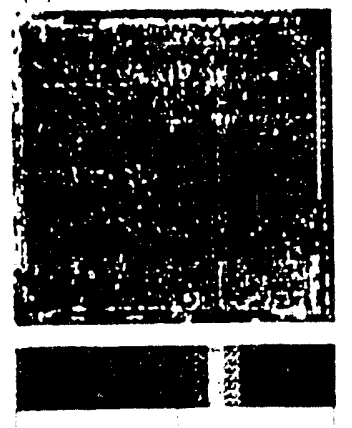

0.85
Figure 8

Top row $(a, b, c, d)$

Lap-joint front

surface temperatures

flash lamp side

Bottom row $(\theta, f, g, h)$

Lap-joint back

ourface temperatures

Figure?
(a) Lap-joint $10 \mathrm{~km}$
(b) Lap-joint 5 um
(c) Temperature map
(d) Emissivity-ratio map 

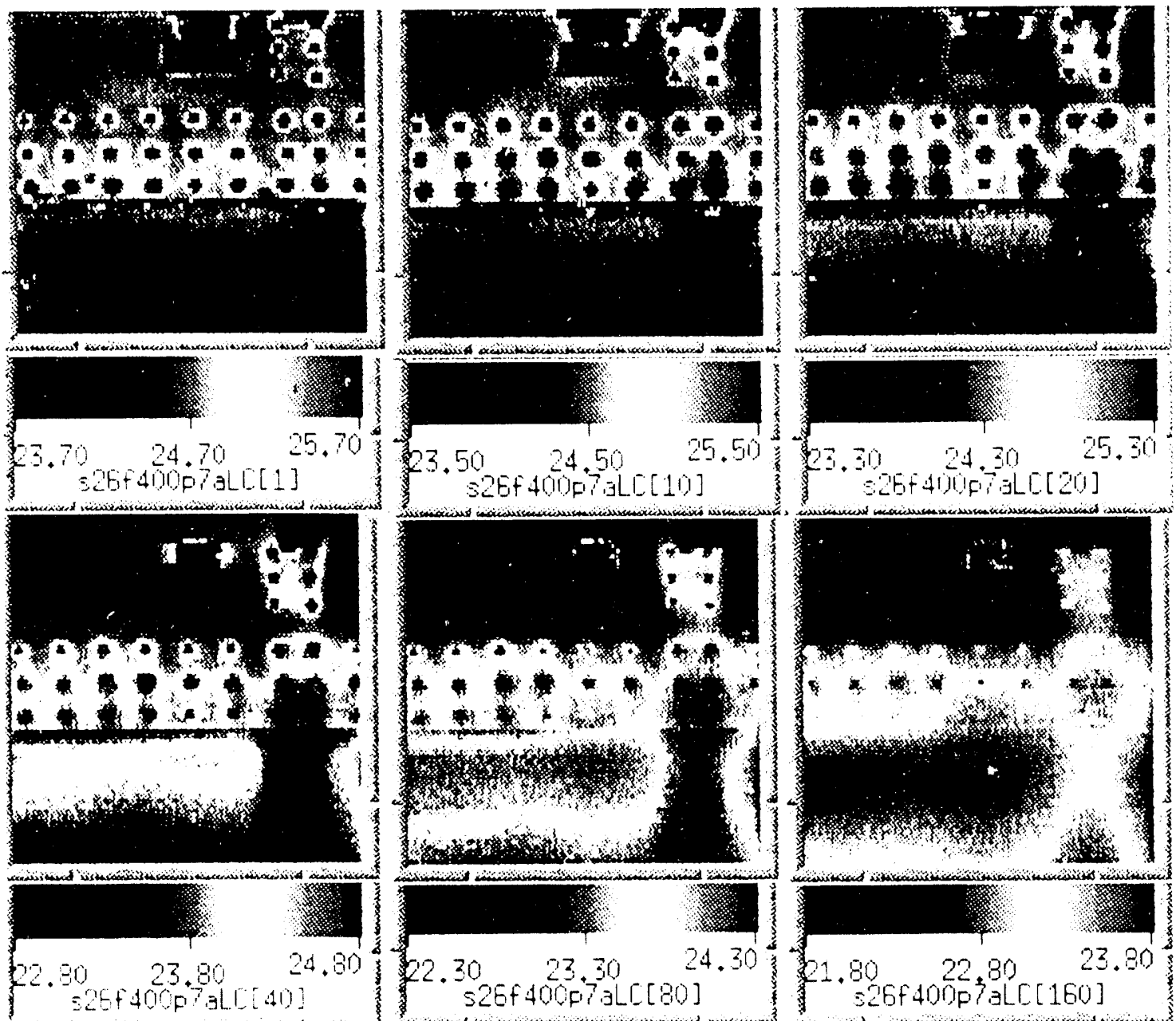

top row: 0.014

bottom row: 1.60 s
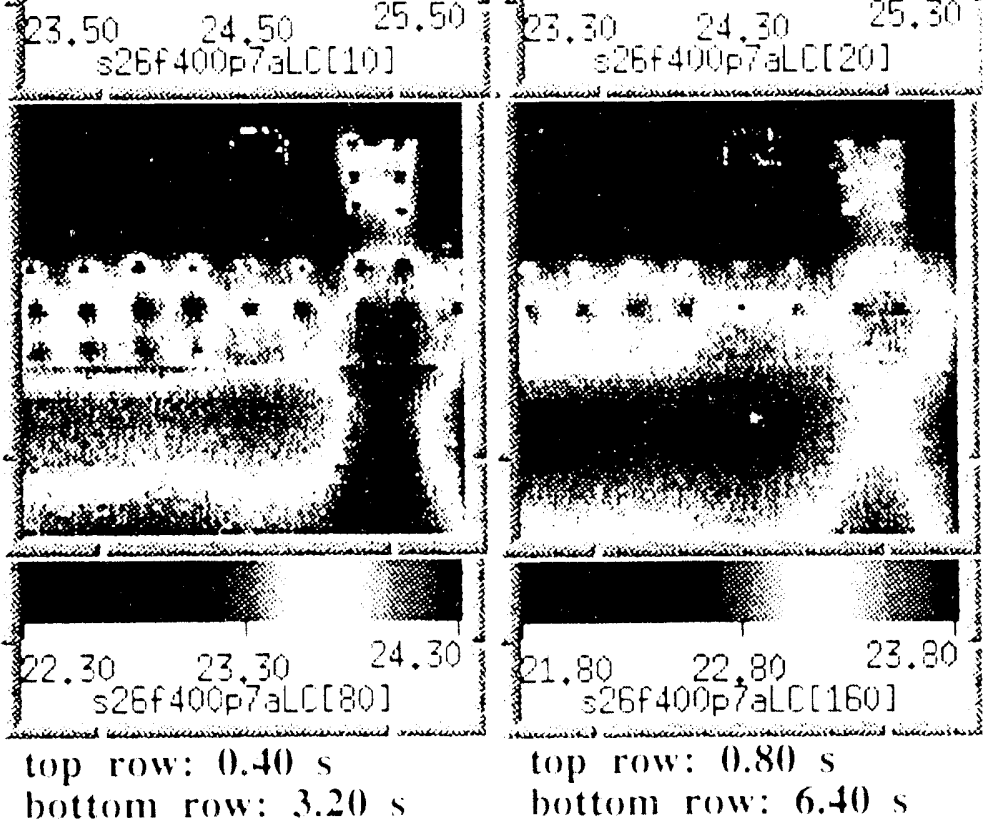

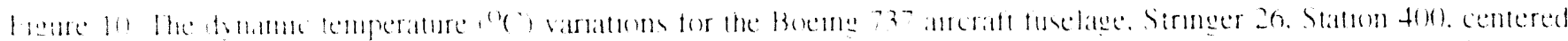

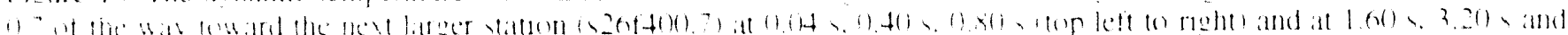

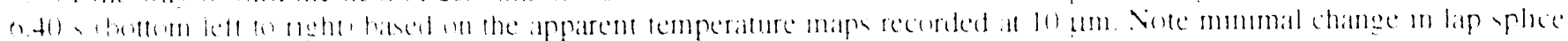

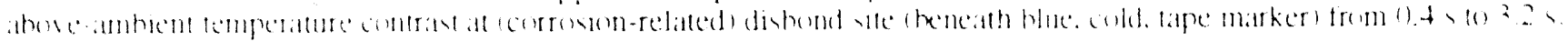

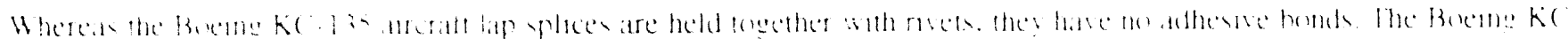

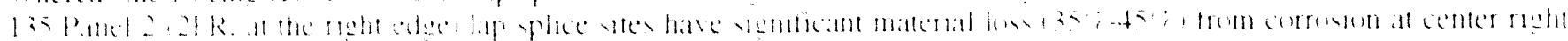

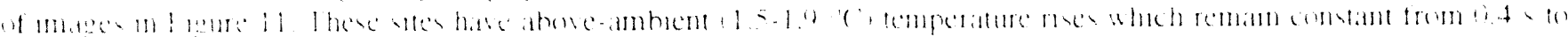

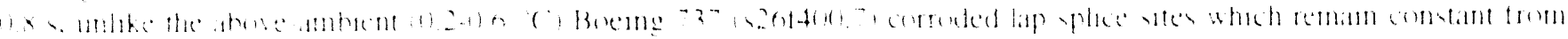
$1+11: 2:$

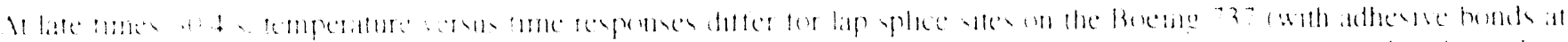

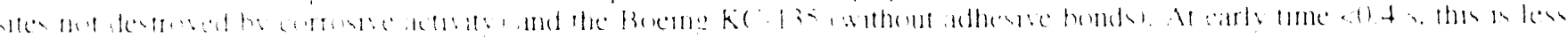

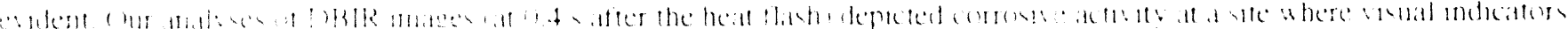

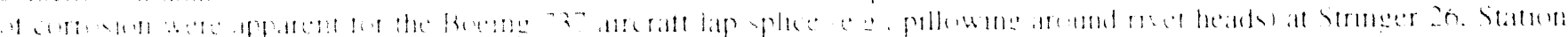

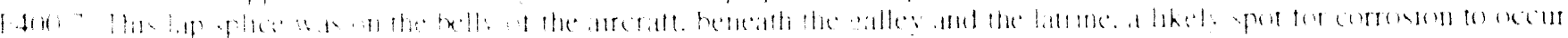



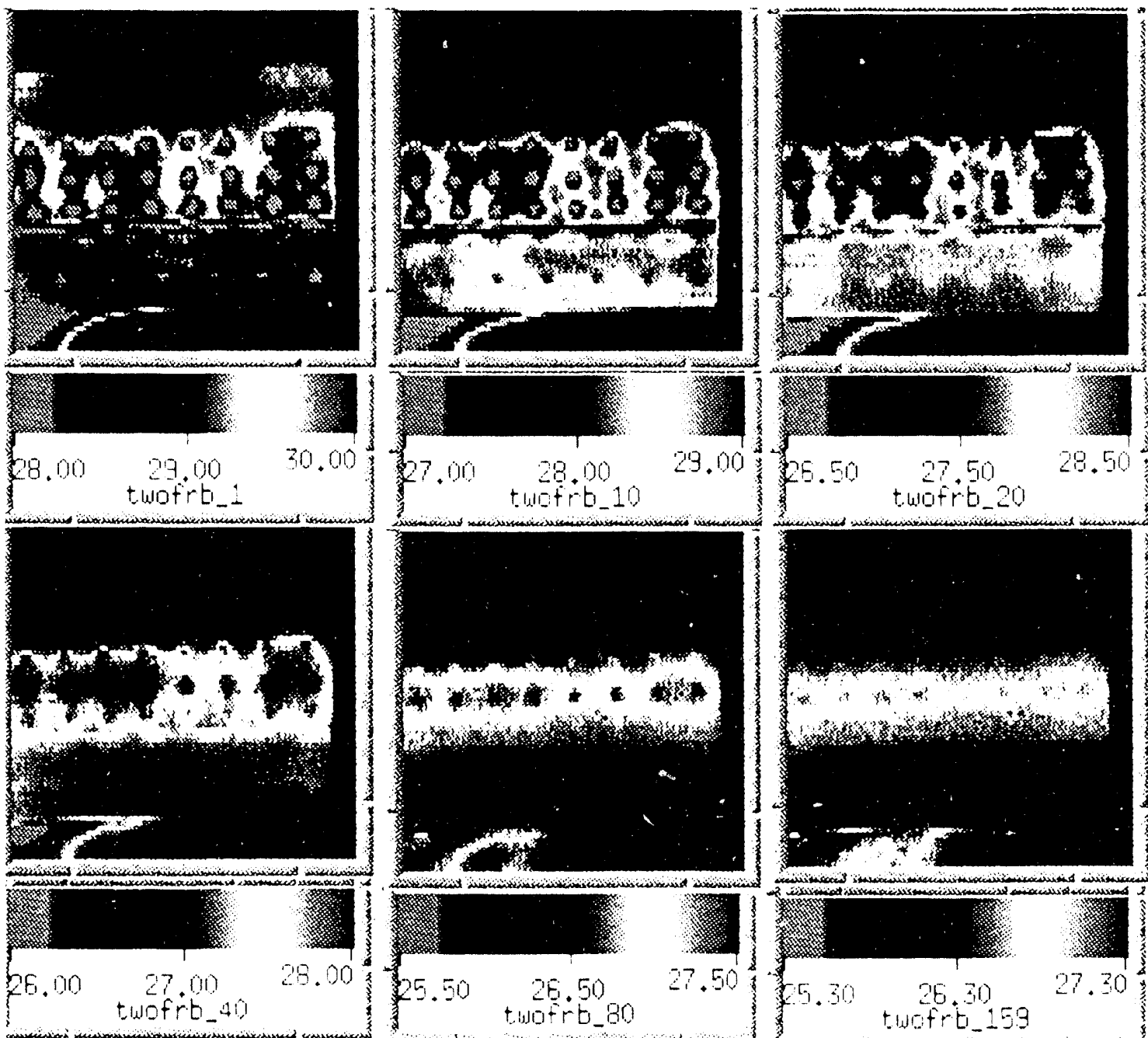

top row: $0 .(04$ s
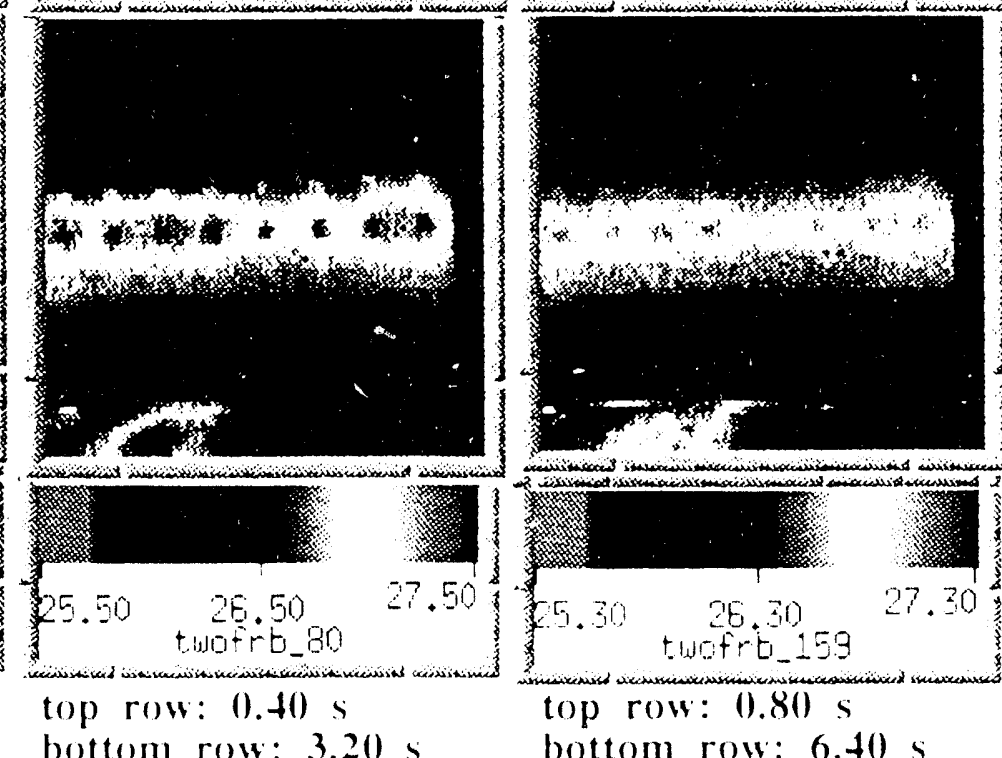

bottom row: 1.60 s

top row: 0.40 s

bottom row: 3.20

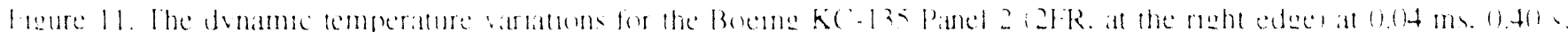

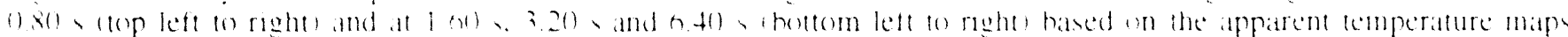
recorided al $10 \mathrm{~mm}$.

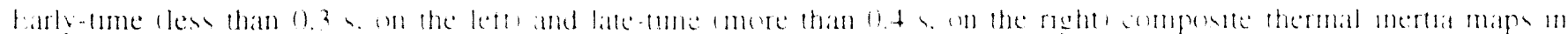

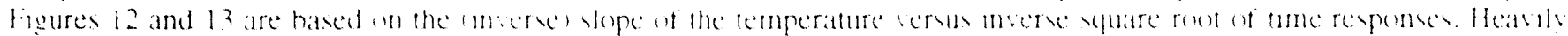

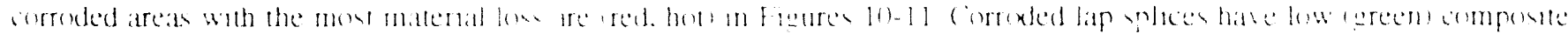

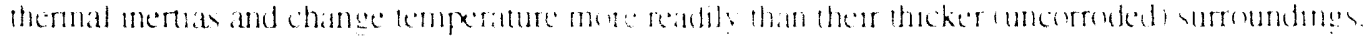

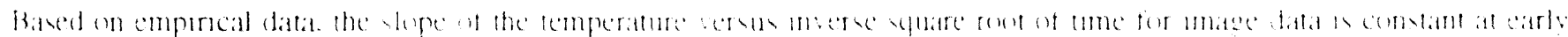

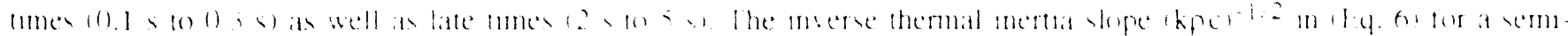

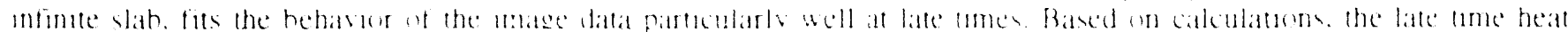

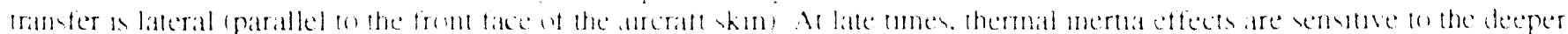

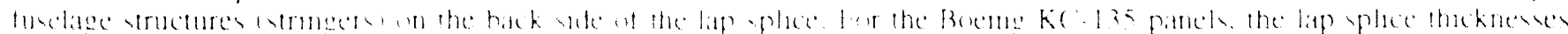

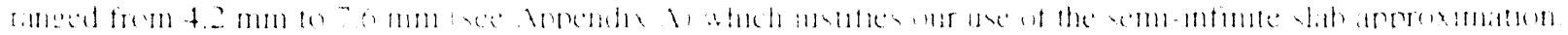



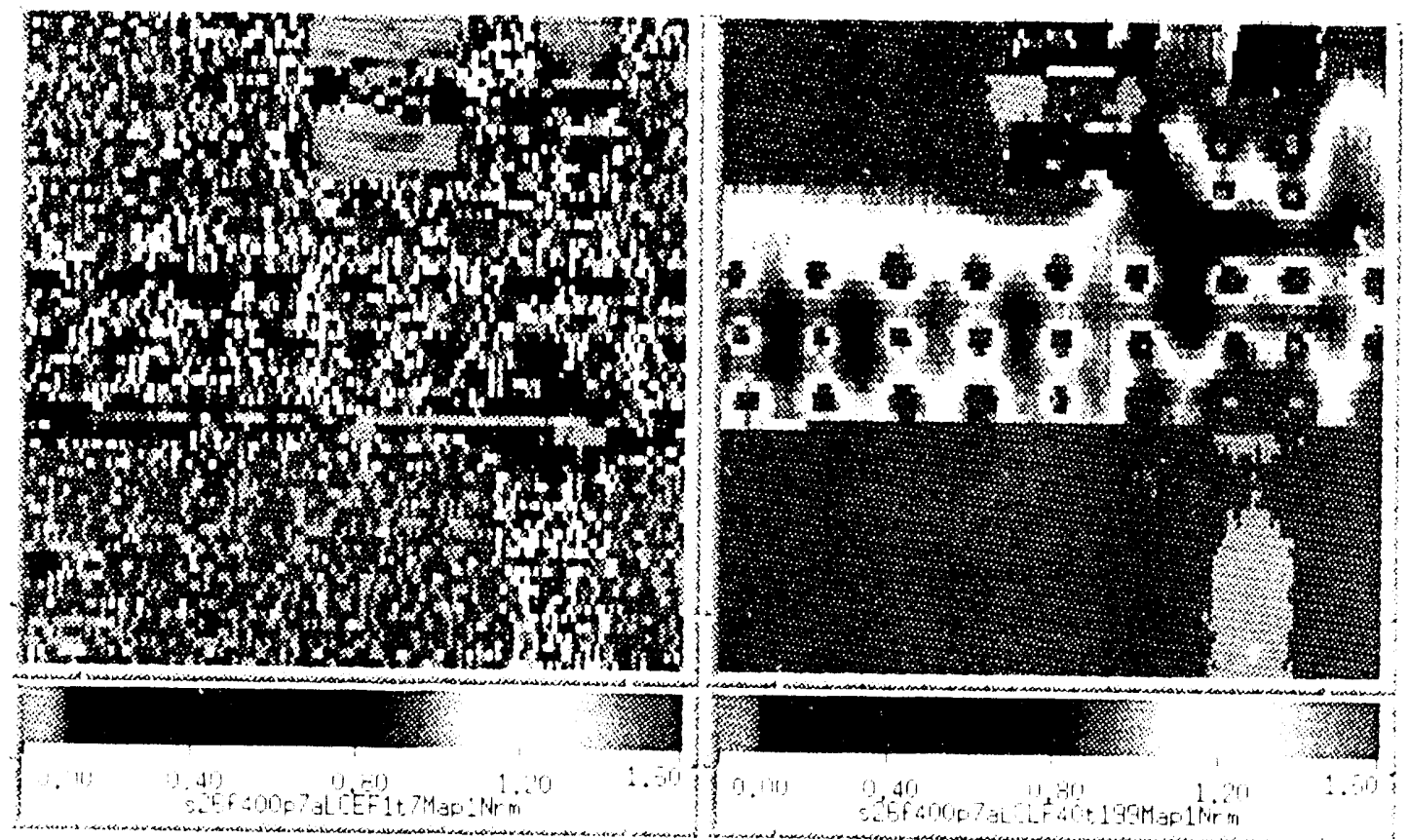

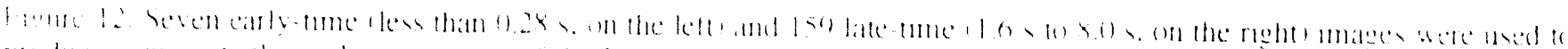

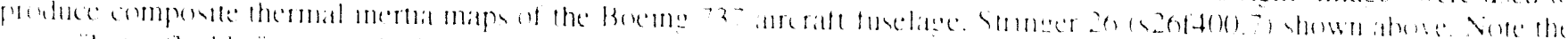

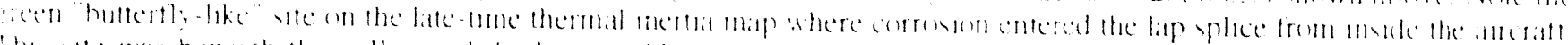

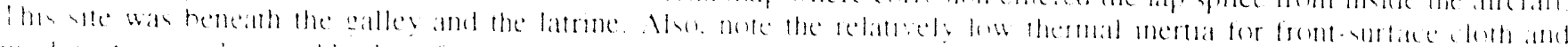

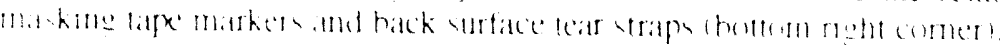
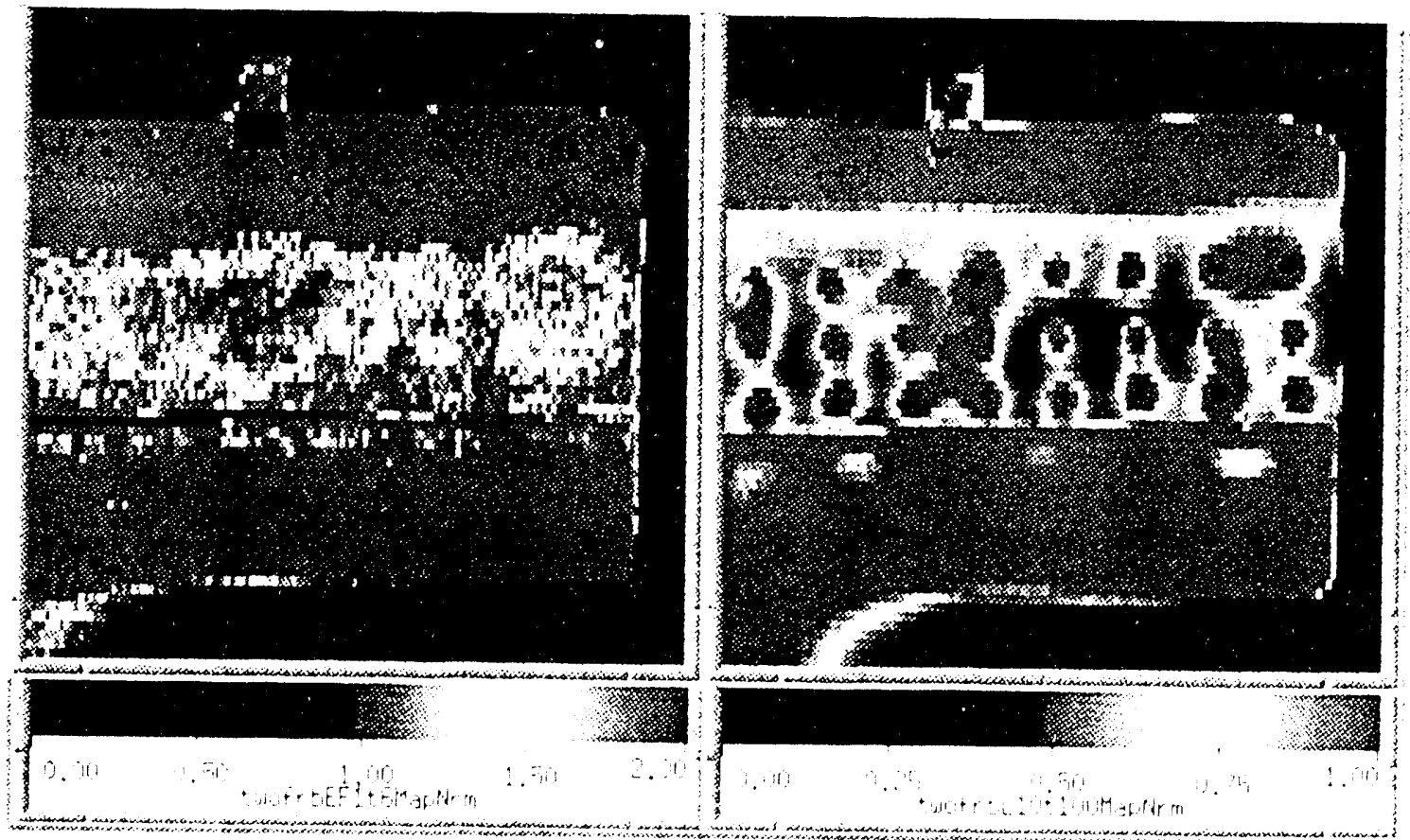

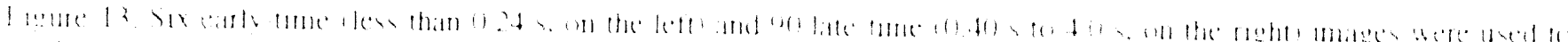

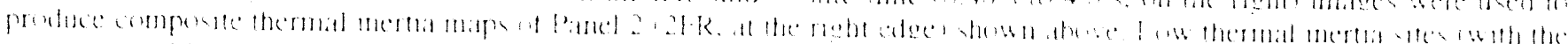

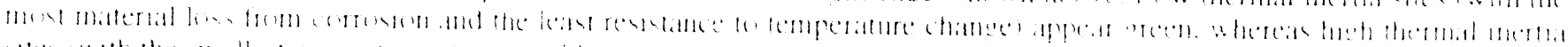

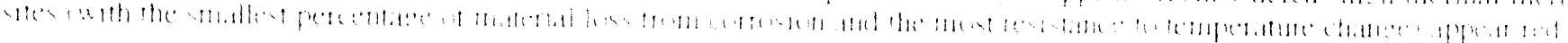




\subsection{FAA/AANC LIBRARY SAMPLES AND BOEING 737 AIRCRAFT: CORROSION TABLES}

For photographs of the FAA/AANC Boeing Aircraft at the Sandia hangar in Albuquerque, New Mexico, see Appendix A. The correlation between above ambient surface temperature and percentage of material loss from corrosion is established using a corroded F-18 wing box structure and four aluminum plates with milled, flat-bottom holes (see Table 1 and Appendix A). The Agema 880 Burst Recording Unit (BRU) 1.3 gigabyte external hard drive stored the DBIR image data discussed below.

We recorded twenty-four 12 bit digital images from the flash-heated samples scanned at $5 \mu \mathrm{m}$ and $10 \mu \mathrm{m}$ with the Agema DBIR cameras. These images are shown at 0.4 seconds after the heat flash (see Appendix B). For temperatures recorded at 10 $\mu \mathrm{m}$ (in ${ }^{\circ} \mathrm{C}$ ) at eight spots midway between rivets, an area box and profiles along the lap splice, see images in Appendix $B$. Tables 1-3 summarize our analyses of FAA/AANC image data at 8 spots on each corrosion sample, calibration plate or Boeing 737 Aircraft lap splice, the locations of which are shown in Appendix B. The tables show the measured percent material loss from corrosion relative to a site with the least corrosion for each image. Histogram charts of Table 1-3 data are shown (from left to right, sites $0-7$ ) with percent material loss relative to the minimum value. Figures 14-16 are based on Table 1, Figures 17-19 on Table 2 and Figures 20-22 on Table 3.

Table 1. Measured $10 \mu \mathrm{m}$ IR temperature differences for FAA/AANC Library Corrosion Panels: C115-C122 and Calibration Panels: B1, B2, B2B3 and S (see Appendix A for photographs and Appendix B for spot locations with relative temperature differences, $\Delta \mathrm{T}$, in ${ }^{\circ} \mathrm{C}$, at $0.4 \mathrm{~s}$ after the heat flash, compared to a cooler site with less material loss from corrosion). We use the correlation of average material loss with above ambient surface temperature rise $0.4 \mathrm{~s}$ after the heat flash which averaged $24 \pm 5 \%$ per $1^{\circ} \mathrm{C}$ for the four panels shown below and the corroded wing box structure (see Table 5, Appendix A, Figure A9, Appendix B, Figure B-6, and Appendix C, Figure C-6).

\begin{tabular}{|c|c|c|c|c|c|c|c|c|c|c|c|c|c|c|}
\hline Sample & Spot & $T$ & $\Delta \mathrm{T}$ & \%Corr & Sample & Spot & $T$ & $\Delta \mathrm{T}$ & $\%$ Corr & Sample & Spot & $\mathrm{T}$ & $\Delta \mathrm{T}$ & \%Loss \\
\hline $\begin{array}{c}\text { C115 } \\
\text { Aver. } \\
\text { \%Corr. } \\
\text { (StD) } \\
8.4 \\
(3.2)\end{array}$ & $\begin{array}{l}0 \\
1 \\
2 \\
3 \\
4 \\
5 \\
6 \\
7\end{array}$ & $\begin{array}{l}21.6 \\
21.6 \\
25.2 \\
21.7 \\
21.8 \\
22.0 \\
21.9 \\
21.7\end{array}$ & $\begin{array}{l}0.2 \\
0.2 \\
3.8 \\
0.3 \\
0.4 \\
0.6 \\
0.5 \\
0.3\end{array}$ & $\begin{array}{c}5 \\
5 \\
\text { n.a. } \\
7 \\
9 \\
14 \\
12 \\
7\end{array}$ & $\begin{array}{c}\text { C119 } \\
\text { Aver. } \\
\text { \%Corr. } \\
\text { (StD) } \\
9.1 \\
(2.9)\end{array}$ & $\begin{array}{l}0 \\
1 \\
2 \\
3 \\
4 \\
5 \\
6 \\
7\end{array}$ & $\begin{array}{l}23.4 \\
23.4 \\
23.6 \\
23.7 \\
23.7 \\
23.7 \\
23.6 \\
23.2 \\
\end{array}$ & $\begin{array}{l}0.2 \\
0.2 \\
0.4 \\
0.5 \\
0.5 \\
0.5 \\
0.4 \\
0.0\end{array}$ & $\begin{array}{c}5 \\
5 \\
9 \\
12 \\
12 \\
12 \\
9 \\
0 \\
\end{array}$ & $\begin{array}{c}\text { B1 } \\
\% \text { Loss } \\
0=9 \% \\
2=19 \% \\
4=28 \% \\
\\
1.1 \mathrm{~mm}\end{array}$ & $\begin{array}{l}0 \\
1 \\
2 \\
3 \\
4 \\
5 \\
6 \\
7 \\
\end{array}$ & $\begin{array}{l}30.8 \\
30.7 \\
31.3 \\
30.5 \\
31.7 \\
30.5 \\
30.7 \\
30.3 \\
\end{array}$ & $\begin{array}{r}0.3 \\
0.2 \\
0.8 \\
0.0 \\
1.2 \\
0.0 \\
0.2 \\
-0.2 \\
\end{array}$ & $\begin{array}{c}7(2) \\
\text { n.a. } \\
19(4) \\
0 \\
29(6) \\
0 \\
\text { n.a. } \\
\text { n.a. }\end{array}$ \\
\hline $\begin{array}{c}\text { C116 } \\
\text { Aver. } \\
\text { \%Corr. } \\
(\mathrm{StD}) \\
10 \\
(1.8)\end{array}$ & $\begin{array}{l}0 \\
1 \\
2 \\
3 \\
4 \\
5 \\
6 \\
7 \\
\end{array}$ & $\begin{array}{l}25.1 \\
25.4 \\
25.5 \\
25.6 \\
25.6 \\
25.5 \\
25.6 \\
25.5 \\
\end{array}$ & $\begin{array}{l}0.0 \\
0.3 \\
0.4 \\
0.5 \\
0.5 \\
0.4 \\
0.5 \\
0.4 \\
\end{array}$ & $\begin{array}{c}9 \\
7 \\
9 \\
12 \\
12 \\
9 \\
12 \\
9 \\
\end{array}$ & $\begin{array}{c}\text { C120 } \\
\text { Aver. } \\
\text { \%Corr. } \\
\text { (StD) } \\
7 \\
(4.4)\end{array}$ & $\begin{array}{l}0 \\
1 \\
2 \\
3 \\
4 \\
5 \\
6 \\
7 \\
\end{array}$ & $\begin{array}{l}22.1 \\
22.1 \\
22.2 \\
22.4 \\
22.5 \\
22.5 \\
22.5 \\
22.1 \\
\end{array}$ & $\begin{array}{l}0.1 \\
0.1 \\
0.2 \\
0.4 \\
0.5 \\
0.5 \\
0.5 \\
0.1 \\
\end{array}$ & $\begin{array}{c}2 \\
2 \\
5 \\
9 \\
12 \\
12 \\
12 \\
2 \\
\end{array}$ & $\begin{array}{c}\text { PanS } \\
\% \text { Loss } \\
0=20 \% \\
2=40 \% \\
4=62 \% \\
1.0 \mathrm{~mm}\end{array}$ & $\begin{array}{l}0 \\
1 \\
2 \\
3 \\
4 \\
5 \\
6 \\
7 \\
\end{array}$ & $\begin{array}{l}34.6 \\
33.9 \\
36.3 \\
34.2 \\
38.7 \\
34.0 \\
34.0 \\
34.0 \\
\end{array}$ & $\begin{array}{c}0.6 \\
-0.1 \\
2.3 \\
0.2 \\
4.7 \\
0.0 \\
0.0 \\
0.0 \\
\end{array}$ & $\begin{array}{c}14(6) \\
\text { n.a. } \\
52(22) \\
\text { n.a. } \\
107(46) \\
0 \\
0 \\
0\end{array}$ \\
\hline $\begin{array}{c}\text { C117 } \\
\text { Aver. } \\
\text { \%Corr. } \\
\text { (StD) } \\
9.5 \\
(4.3)\end{array}$ & $\begin{array}{l}0 \\
1 \\
2 \\
3 \\
4 \\
5 \\
6 \\
7 \\
\end{array}$ & $\begin{array}{l}23.0 \\
23.2 \\
23.2 \\
23.4 \\
23.4 \\
23.4 \\
23.6 \\
23.2 \\
\end{array}$ & $\begin{array}{l}0.1 \\
0.3 \\
0.3 \\
0.5 \\
0.5 \\
0.5 \\
0.7 \\
0.3 \\
\end{array}$ & $\begin{array}{l}2 \\
7 \\
7 \\
12 \\
12 \\
12 \\
17 \\
7\end{array}$ & $\begin{array}{c}\text { C121 } \\
\text { Aver. } \\
\text { \%Corr. } \\
\text { (StD) } \\
11.5 \\
(2.1)\end{array}$ & $\begin{array}{l}0 \\
1 \\
2 \\
3 \\
4 \\
5 \\
6 \\
7 \\
\end{array}$ & $\begin{array}{l}23.3 \\
23.4 \\
23.7 \\
23.9 \\
23.9 \\
24.0 \\
23.9 \\
23.9 \\
\end{array}$ & $\begin{array}{l}-0.1 \\
0.0 \\
0.3 \\
0.5 \\
0.5 \\
0.6 \\
0.5 \\
0.5 \\
\end{array}$ & $\begin{array}{c}\text { n.a. } \\
0 \\
7 \\
12 \\
12 \\
14 \\
12 \\
12 \\
\end{array}$ & $\begin{array}{c}\text { B2 } \\
\text { \%Loss } \\
0=10 \% \\
2=19 \% \\
4=28 \% \\
\\
2.3 \mathrm{~mm}\end{array}$ & $\begin{array}{l}0 \\
1 \\
2 \\
3 \\
4 \\
5 \\
6 \\
7 \\
\end{array}$ & $\begin{array}{l}28.2 \\
28.1 \\
28.6 \\
28.1 \\
28.9 \\
28.2 \\
28.1 \\
28.1 \\
\end{array}$ & $\begin{array}{l}0.3 \\
0.2 \\
0.7 \\
0.2 \\
1.0 \\
0.3 \\
0.2 \\
0.2\end{array}$ & $\begin{array}{c}9(1) \\
\text { n.a. } \\
22(3) \\
\text { n.a. } \\
32(4) \\
\text { n.a. } \\
\text { n.a. } \\
\text { n.a. }\end{array}$ \\
\hline $\begin{array}{c}\text { C118 } \\
\text { Aver. } \\
\text { \%Corr. } \\
\text { (StD) } \\
11.3 \\
(2.6)\end{array}$ & $\begin{array}{l}0 \\
1 \\
2 \\
3 \\
4 \\
5 \\
6 \\
7\end{array}$ & $\begin{array}{l}23.7 \\
24.2 \\
24.4 \\
24.3 \\
24.5 \\
24.5 \\
24.4 \\
23.8\end{array}$ & $\begin{array}{c}-0.2 \\
0.3 \\
0.5 \\
0.4 \\
0.6 \\
0.6 \\
0.5 \\
-0.1\end{array}$ & $\begin{array}{c}\text { n.a. } \\
7 \\
12 \\
9 \\
14 \\
14 \\
12 \\
\text { n.a. }\end{array}$ & $\begin{array}{c}\mathrm{C} 122 \\
\text { Aver. } \\
\text { \%Corr. } \\
\text { (StD) } \\
11.9 \\
(1.4)\end{array}$ & $\begin{array}{l}0 \\
1 \\
2 \\
3 \\
4 \\
5 \\
6 \\
7\end{array}$ & $\begin{array}{l}23.4 \\
23.9 \\
24.0 \\
23.9 \\
23.9 \\
23.9 \\
23.9 \\
23.8\end{array}$ & $\begin{array}{l}0.0 \\
0.5 \\
0.6 \\
0.5 \\
0.5 \\
0.5 \\
0.5 \\
0.4\end{array}$ & $\begin{array}{l}0 \\
12 \\
14 \\
12 \\
12 \\
12 \\
12 \\
9\end{array}$ & $\begin{array}{c}\text { B2B3 } \\
\text { \%Loss } \\
0=6 \% \\
2=12 \% \\
4=17 \% \\
\\
3.9 \mathrm{~mm}\end{array}$ & $\begin{array}{l}0 \\
1 \\
2 \\
3 \\
4 \\
5 \\
6 \\
7\end{array}$ & $\begin{array}{l}28.9 \\
28.6 \\
29.3 \\
28.6 \\
29.6 \\
28.4 \\
28.7 \\
28.6 \\
\end{array}$ & $\begin{array}{c}0.3 \\
0.0 \\
0.7 \\
0.0 \\
1.0 \\
-0.2 \\
0.1 \\
0.0\end{array}$ & $\begin{array}{c}5(1) \\
0 \\
12(2) \\
0 \\
17(3) \\
\text { n.a. } \\
\text { n.a. } \\
0\end{array}$ \\
\hline
\end{tabular}




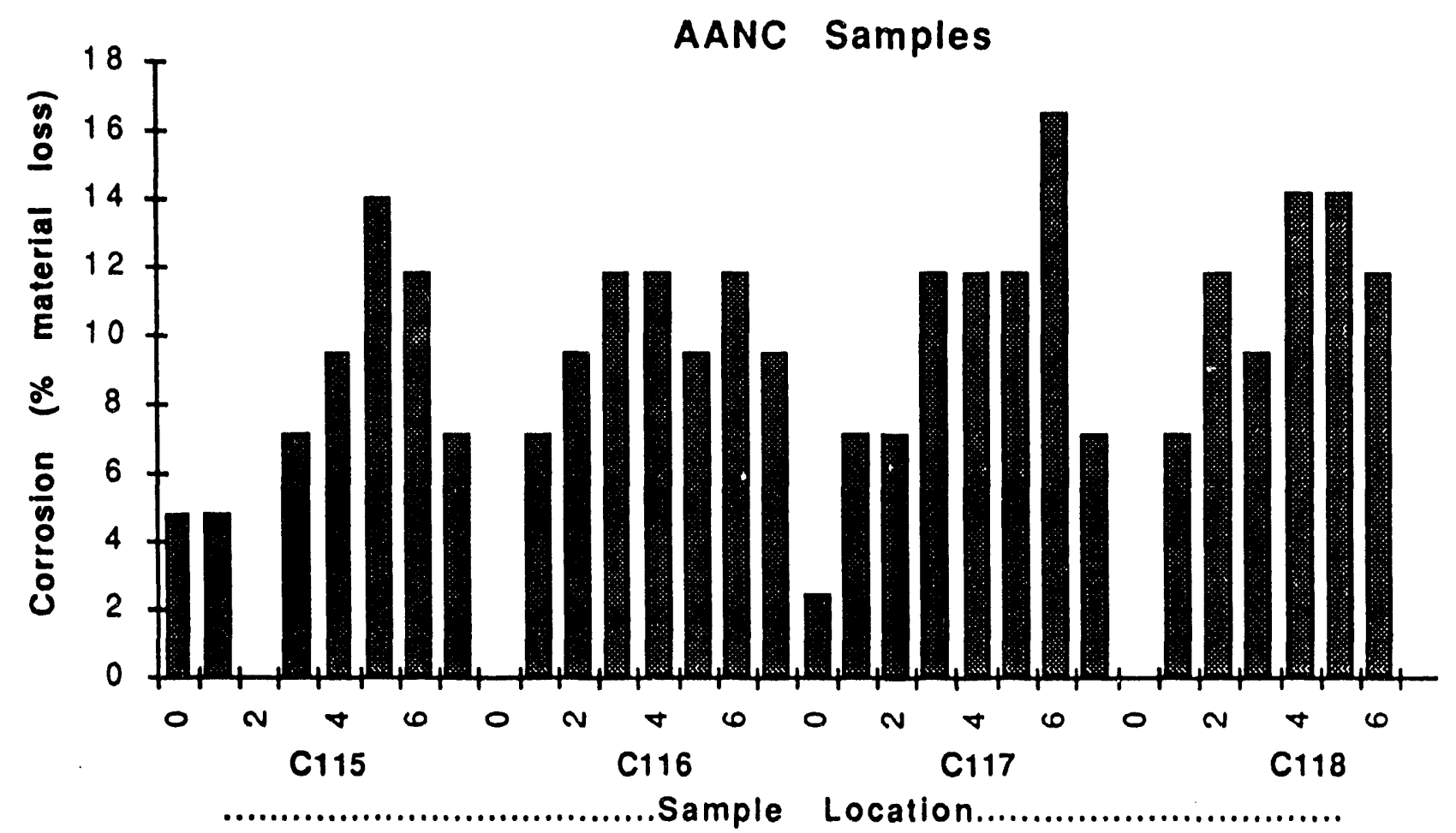

Figure 14. Corrosion chart showing sites between lap joint rivets for FAA/AANC Library Panels C115 and C116 without and $\mathrm{C} 117$ and $\mathrm{C} 118$ with 27 days exposure to solutions expected to cause corrosive action. See Table 1 and Appendix B.

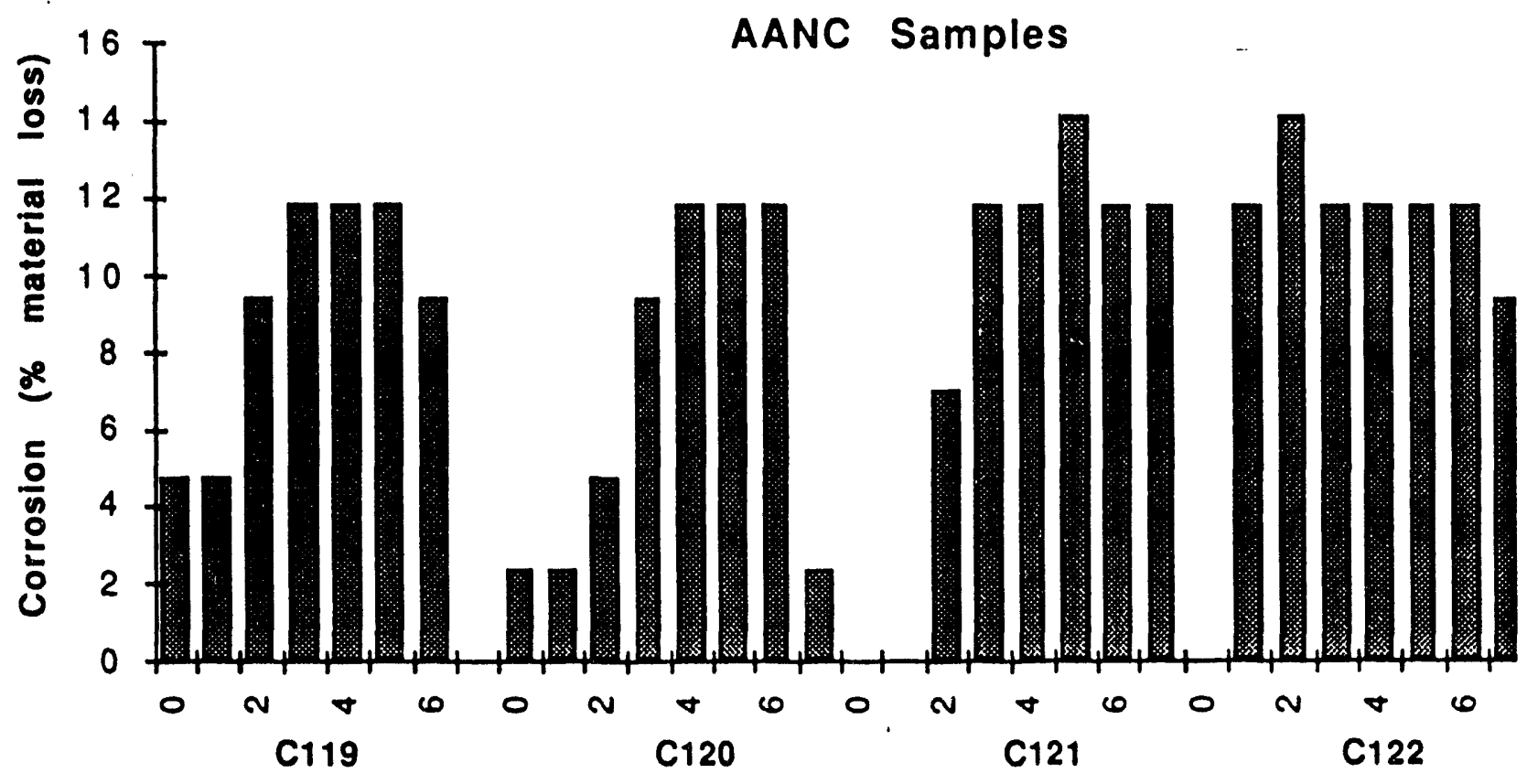

Sample Location................................

Figure 15. Corrosion chart showing sites between lap joint rivets for FAA/AANC Library Panels $\mathrm{Cl} 19$ and $\mathrm{C} 120$ with 42 days and $\mathrm{C} 121$ and $\mathrm{C} 122$ with 54 days exposure to solutions expected to cause corrosive action. See Table 1 and Appendix B. 


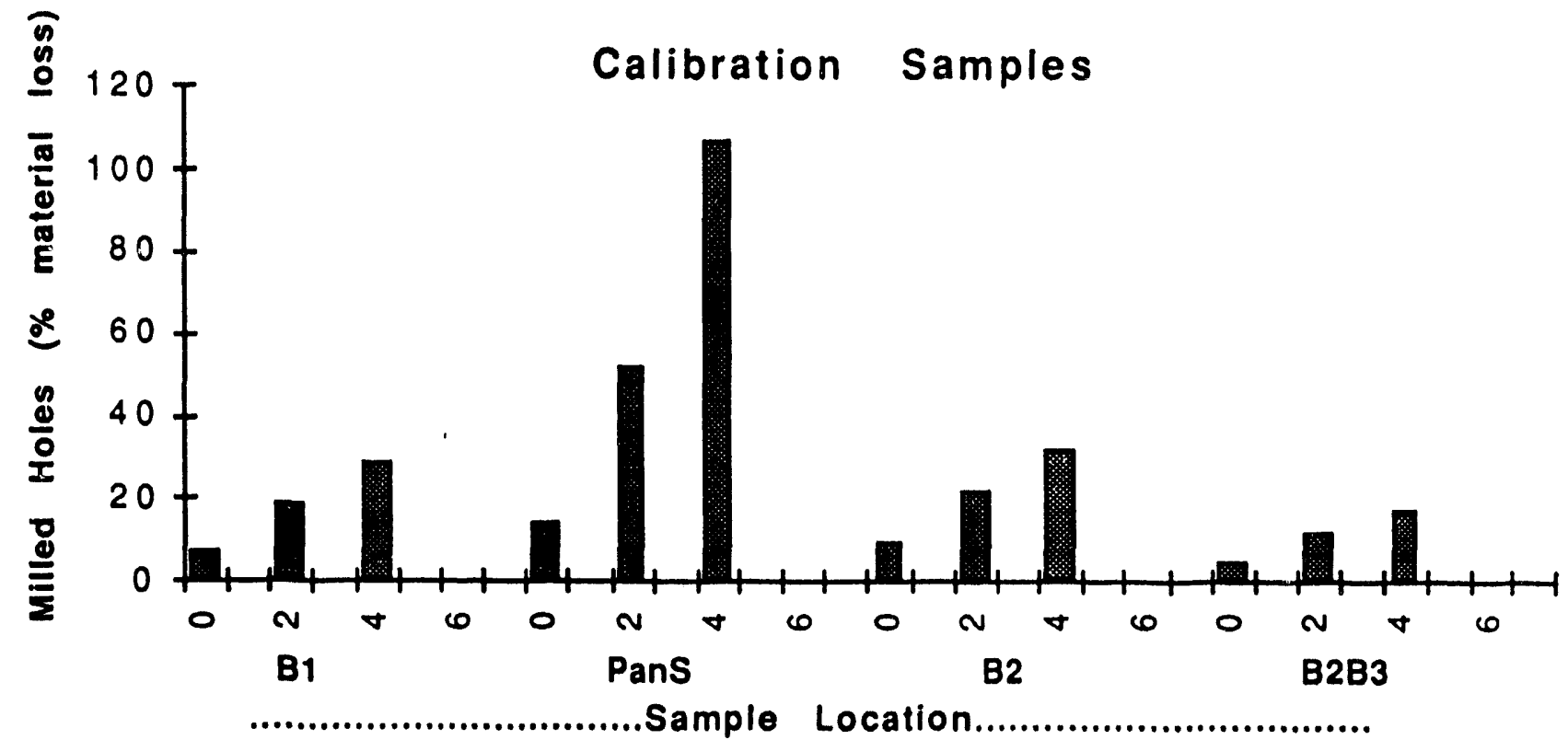

Figure 16. Chart showing thickness losses which were proportional to surface temperature rises at $0.4 \mathrm{~s}$ after flash-heating calibration samples: B1 $(1.1 \mathrm{~mm})$, PanS $(1.0 \mathrm{~mm})$, B2 $(2.3 \mathrm{~mm})$ and B2B3 $(3.9 \mathrm{~mm})$. Samples were black-painted aluminum plates with milled flat-bottom holes. See Table 1 for statistical errors and Appendix A for the color-coded thermal images.

We established the correlation between percent thickness loss and degree Celsius surface temperature rise, at 0.4 seconds after the heat flash, based on measurements for the following five specimens:

- F-18 corroded wing box structure from Northrop Corporation ( $2.9 \mathrm{~mm}$ uncorroded thickness): $22 . \overline{1} \pm 6.0 \%$ per ${ }^{\circ} \mathrm{C}$

- LLNL panel with milled flat-bottom holes, PanS (1.0 mm thickness): $22.7 \pm 10.0 \%$ per ${ }^{\circ} \mathrm{C}$

- Bales Scientific Instruments milled flat-bottom panel from Delta Airlines, B1 (1.1 mm thickness): $25.8+4.5 \%$ per ${ }^{\circ} \mathrm{C}$

- Bales Scientific Instruments milled flat-bottom panel from Delta Airlines, B2 (2.3 mm thickness): $31.5+4.8 \%$ per ${ }^{\circ} \mathrm{C}$

- LLNL aluminum plate, B3 (1.5 mm), combined with B2 to form B2B3 (3.9 mm thickness): $17.2+1.8 \%$ per ${ }^{\circ} \mathrm{C}$

The average of the above five specimen measurements was $24 \pm 5 \%$ per ${ }^{\circ} \mathrm{C}$ thickness loss which we used to analyze the Boeing 737 and KC-135 panels described in Tables 1.5 and Appendices A, B and C. 
Table 2. Measured $10 \mu \mathrm{m}$ IR temperature differences for FAA/AANC Boeing 737 Aircraft lap splice, Stringer 26. See Appendix $A$ for photographs and Appendix $B$ for spot locations with relative temperature differences, $\Delta T$, in ${ }^{\circ} \mathrm{C}$, at $0.4 \mathrm{~s}$ after the hea' flash, compared to a cooler site with less material loss from corrosion. We use the correlation of average material loss with above ambient surface temperature rise $0.4 \mathrm{~s}$ after the heat flash which averaged $24 \pm 5 \%$ per $1{ }^{\circ} \mathrm{C}$.

\begin{tabular}{|c|c|c|c|c|c|c|c|c|c|c|c|c|c|c|}
\hline Site & Spot & $T$ & $\Delta T$ & $\%$ Corr & Site & Spot & $T$ & $\Delta \mathrm{T}$ & $\%$ Corr & Site & Spot & $\bar{T}$ & $\Delta T$ & $\%$ Cor \\
\hline $\begin{array}{c}s 26 \\
f 460.3 \\
\max \% \\
12 \\
(3)\end{array}$ & $\begin{array}{l}0 \\
1 \\
2 \\
3 \\
4 \\
5 \\
6 \\
7 \\
\end{array}$ & $\begin{array}{l}25.2 \\
25.3 \\
24.9 \\
25.0 \\
25.4 \\
25.2 \\
25.4 \\
25.3 \\
\end{array}$ & $\begin{array}{l}0.3 \\
0.4 \\
0.0 \\
0.1 \\
0.5 \\
0.3 \\
0.5 \\
0.4 \\
\end{array}$ & $\begin{array}{c}7 \\
9 \\
0 \\
2 \\
12 \\
7 \\
12 \\
10 \\
\end{array}$ & $\begin{array}{c}s 26 \\
\mathrm{f} 420.5 \\
\max \% \\
14 \\
(4)\end{array}$ & $\begin{array}{l}0 \\
1 \\
2 \\
3 \\
4 \\
5 \\
6 \\
7 \\
\end{array}$ & $\begin{array}{l}25.8 \\
25.6 \\
25.4 \\
25.5 \\
25.5 \\
25.3 \\
25.4 \\
25.3 \\
\end{array}$ & $\begin{array}{l}0.6 \\
0.4 \\
0.2 \\
0.3 \\
0.3 \\
0.1 \\
0.2 \\
0.1 \\
\end{array}$ & $\begin{array}{l}14 \\
9 \\
5 \\
7 \\
7 \\
2 \\
5 \\
2 \\
\end{array}$ & $\begin{array}{c}\mathrm{s} 26 \\
\mathrm{~B} 80.5 \\
\max \% \\
12 \\
(3)\end{array}$ & $\begin{array}{l}0 \\
1 \\
2 \\
3 \\
4 \\
5 \\
6 \\
7 \\
\end{array}$ & $\begin{array}{l}23.8 \\
23.9 \\
23.7 \\
23.6 \\
23.7 \\
23.4 \\
23.6 \\
23.7 \\
\end{array}$ & $\begin{array}{l}0.4 \\
0.5 \\
0.3 \\
0.2 \\
0.3 \\
0.0 \\
0.2 \\
0.3\end{array}$ & $\begin{array}{c}9 \\
12 \\
7 \\
5 \\
7 \\
0 \\
5 \\
7 \\
\end{array}$ \\
\hline $\begin{array}{c}s 26 \\
\mathrm{f} 440.8 \\
\max \% \\
9 \\
(3)\end{array}$ & $\begin{array}{l}0 \\
1 \\
2 \\
3 \\
4 \\
5 \\
6 \\
7 \\
\end{array}$ & $\begin{array}{l}25.1 \\
24.9 \\
24.9 \\
24.7 \\
24.9 \\
24.9 \\
24.9 \\
24.8 \\
\end{array}$ & $\begin{array}{l}0.4 \\
0.2 \\
0.2 \\
0.0 \\
0.2 \\
0.2 \\
0.2 \\
0.1 \\
\end{array}$ & $\begin{array}{l}9 \\
5 \\
5 \\
0 \\
5 \\
5 \\
5 \\
2 \\
\end{array}$ & $\begin{array}{c}s 26 \\
\mathrm{f} 420 \\
\\
\max \% \\
9 \\
(3)\end{array}$ & $\begin{array}{l}0 \\
1 \\
2 \\
3 \\
4 \\
5 \\
6 \\
7 \\
\end{array}$ & $\begin{array}{l}25.4 \\
25.4 \\
25.4 \\
25.2 \\
25.4 \\
25.4 \\
25.4 \\
25.5\end{array}$ & $\begin{array}{l}0.3 \\
0.3 \\
0.3 \\
0.1 \\
0.3 \\
0.3 \\
0.3 \\
0.4 \\
\end{array}$ & $\begin{array}{l}7 \\
7 \\
7 \\
2 \\
7 \\
7 \\
7 \\
9 \\
\end{array}$ & $\begin{array}{c}\mathrm{s} 26 \\
\mathrm{~B} 80 \\
\max \% \\
12 \\
(3)\end{array}$ & $\begin{array}{l}0 \\
1 \\
2 \\
3 \\
4 \\
5 \\
6 \\
7 \\
\end{array}$ & $\begin{array}{l}20.6 \\
20.5 \\
20.5 \\
21.9 \\
21.8 \\
21.8 \\
21.8 \\
21.4 \\
\end{array}$ & $\begin{array}{l}0.8 \\
-0.9 \\
-0.9 \\
0.5 \\
0.4 \\
0.4 \\
0.4 \\
0.0 \\
\end{array}$ & $\begin{array}{c}\text { n.a. } \\
\text { n.a. } \\
\text { n.a. } \\
12 \\
9 \\
9 \\
9 \\
0 \\
\end{array}$ \\
\hline $\begin{array}{c}s 26 \\
f 440.4 \\
\max \% \\
14 \\
(4)\end{array}$ & $\begin{array}{l}0 \\
1 \\
2 \\
3 \\
4 \\
5 \\
6 \\
7\end{array}$ & $\begin{array}{l}24.8 \\
24.8 \\
24.6 \\
25.8 \\
25.8 \\
25.5 \\
25.4 \\
25.3\end{array}$ & $\begin{array}{l}-0.4 \\
-0.4 \\
-0.6 \\
0.6 \\
0.6 \\
0.3 \\
0.2 \\
0.1\end{array}$ & $\begin{array}{c}\text { na } \\
\text { na } \\
\text { na } \\
14 \\
14 \\
7 \\
5 \\
2\end{array}$ & $\begin{array}{c}\mathrm{s} 26 \\
\{400.7 \\
\max \% \\
14 \\
(4)\end{array}$ & $\begin{array}{l}0 \\
1 \\
2 \\
3 \\
4 \\
5 \\
6 \\
7\end{array}$ & $\begin{array}{l}25.4 \\
25.4 \\
25.3 \\
25.6 \\
25.4 \\
25.6 \\
25.3 \\
25.4\end{array}$ & $\begin{array}{l}0.4 \\
0.4 \\
0.3 \\
0.6 \\
0.4 \\
0.6 \\
0.3 \\
0.4\end{array}$ & $\begin{array}{c}9 \\
9 \\
7 \\
14 \\
9 \\
14 \\
7 \\
9 \\
\end{array}$ & $\begin{array}{c}s 26 \\
1360.5 \\
\max \% \\
12 \\
(3)\end{array}$ & $\begin{array}{l}0 \\
1 \\
2 \\
3 \\
4 \\
5 \\
6 \\
7 \\
\end{array}$ & $\begin{array}{l}25.1 \\
25.0 \\
24.9 \\
25.1 \\
24.9 \\
25.1 \\
24.8 \\
24.8 \\
\end{array}$ & $\begin{array}{l}0.5 \\
0.4 \\
0.3 \\
0.5 \\
0.3 \\
0.5 \\
0.2 \\
0.2 \\
\end{array}$ & $\begin{array}{c}12 \\
9 \\
7 \\
12 \\
7 \\
12 \\
5 \\
5 \\
\end{array}$ \\
\hline $\begin{array}{c}s 26 \\
\mathrm{f} 440 \\
\\
\max \% \\
17 \\
(4)\end{array}$ & $\begin{array}{l}0 \\
1 \\
2 \\
3 \\
4 \\
5 \\
6 \\
7\end{array}$ & $\begin{array}{l}25.8 \\
25.8 \\
25.9 \\
25.4 \\
25.5 \\
25.4 \\
25.2 \\
25.6\end{array}$ & $\begin{array}{l}0.6 \\
0.6 \\
0.7 \\
0.2 \\
0.3 \\
0.2 \\
0.0 \\
0.4\end{array}$ & $\begin{array}{l}14 \\
14 \\
17 \\
5 \\
7 \\
5 \\
0 \\
9\end{array}$ & $\begin{array}{c}\mathrm{s} 26 \\
\mathrm{f} 400.3 \\
\max \% \\
14 \\
(4)\end{array}$ & $\begin{array}{l}0 \\
1 \\
2 \\
3 \\
4 \\
5 \\
6 \\
7\end{array}$ & $\begin{array}{l}25.6 \\
25.4 \\
25.4 \\
25.1 \\
25.3 \\
25.4 \\
25.3 \\
25.1\end{array}$ & $\begin{array}{l}0.6 \\
0.4 \\
0.4 \\
0.1 \\
0.3 \\
0.4 \\
0.3 \\
0.1\end{array}$ & $\begin{array}{l}14 \\
9 \\
9 \\
2 \\
7 \\
9 \\
7 \\
2\end{array}$ & $\begin{array}{c}\mathrm{s} 26 \\
1360 \\
\max \% \\
12 \\
(3)\end{array}$ & $\begin{array}{l}0 \\
1 \\
2 \\
3 \\
4 \\
5 \\
6 \\
7\end{array}$ & $\begin{array}{l}25.4 \\
25.4 \\
25.1 \\
25.4 \\
25.5 \\
26.0 \\
25.1 \\
24.8\end{array}$ & $\begin{array}{c}0.4 \\
0.4 \\
0.1 \\
0.4 \\
0.5 \\
1.0 \\
0.1 \\
-0.2\end{array}$ & $\begin{array}{c}9 \\
9 \\
2 \\
9 \\
12 \\
\text { n.a. } \\
2 \\
\text { n.a. }\end{array}$ \\
\hline
\end{tabular}




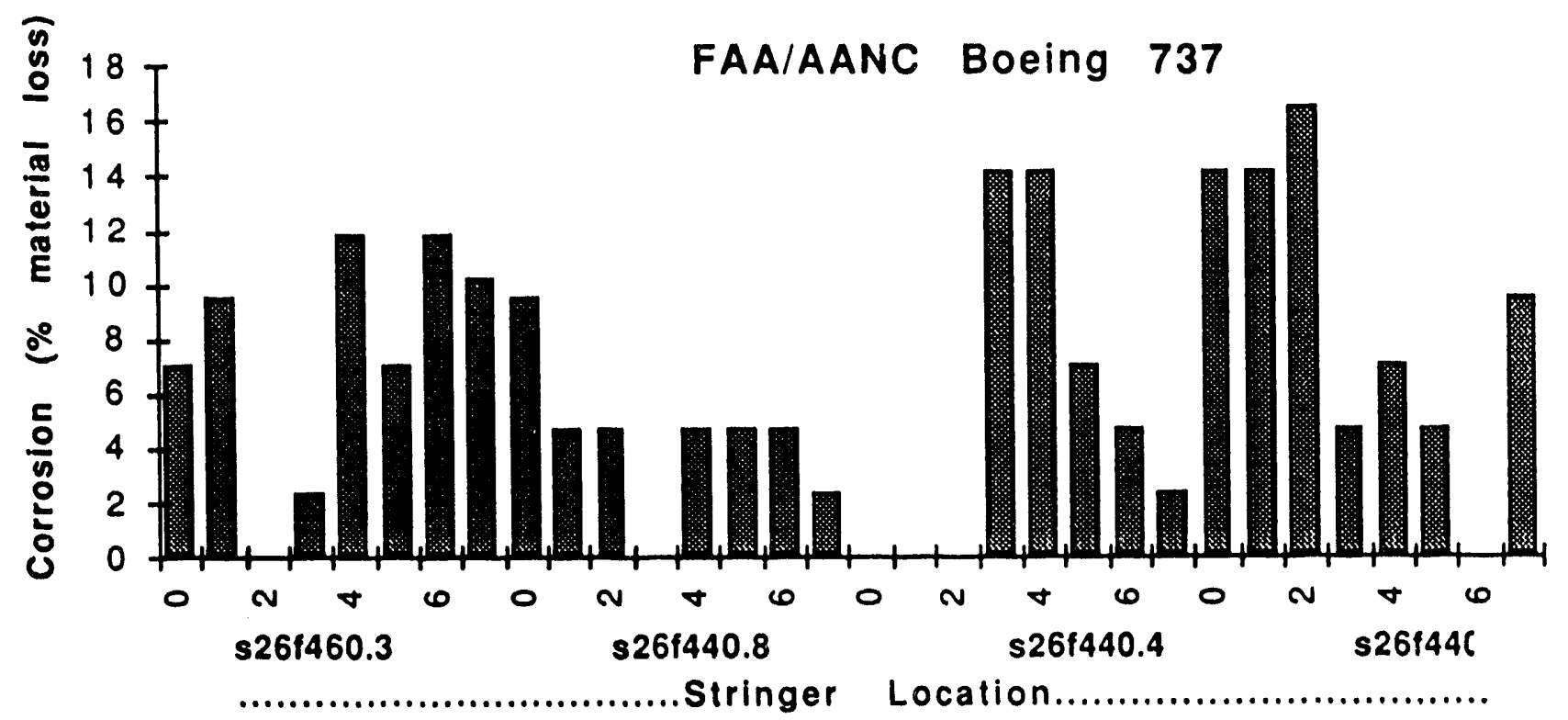

Figure 17. Percent material loss from corrosion, left to right of Stringer 26 images (centered from $30 \%$ aft of Station f460 to Station f440) relative to a cooler area with less material loss from corrosion. Sce Table 2 and Appendix B for spot locations where surface temperature differences were measured.

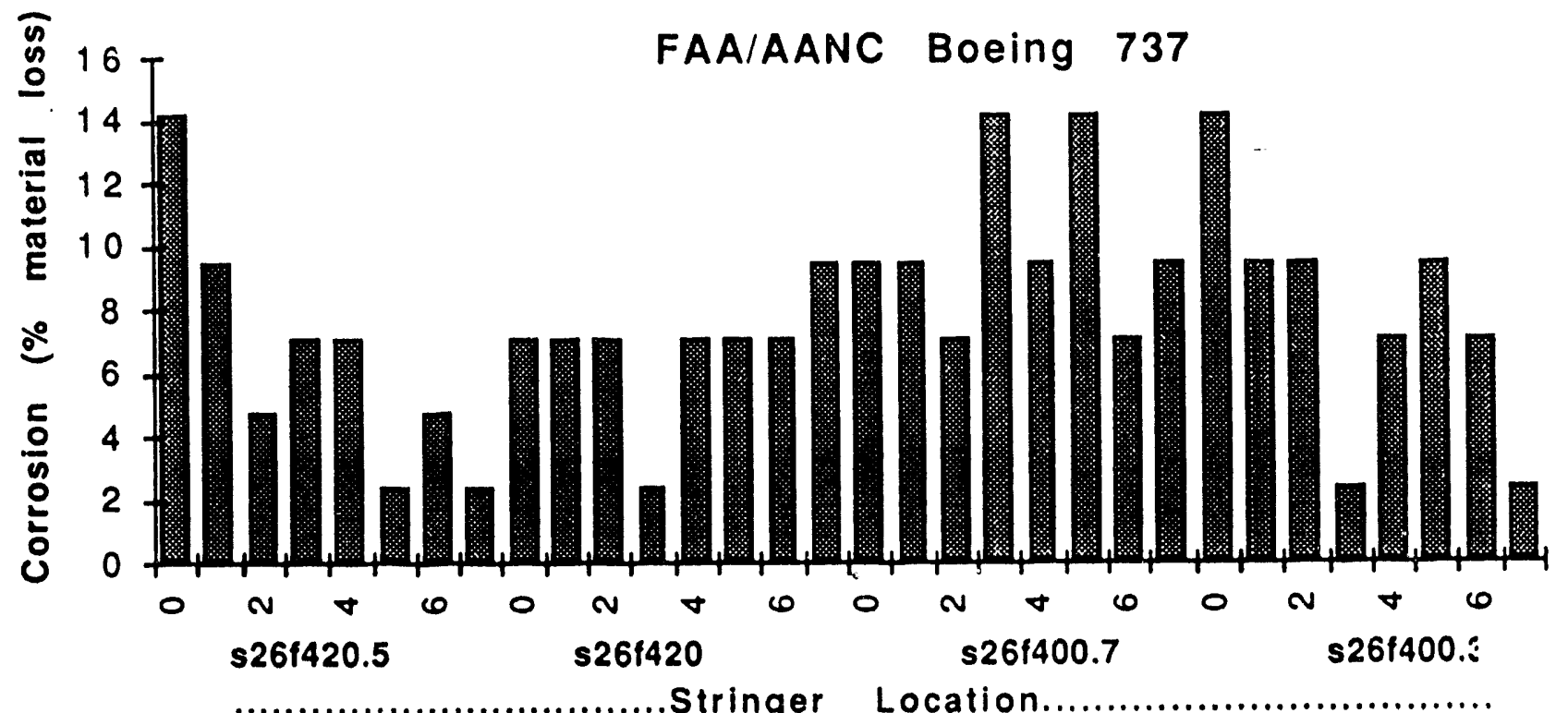

Figure 18. Percent material loss from corrosion, left to right of Stringer 26 images (centered from $50 \%$ aft of Station $f 420$ to $30 \%$ aft of Station $\mathrm{f} 400$ ) relative to a cooler area with less material loss from corrosion. See Table 2 and Appendix B for spol locations where surface temperature differences were measured. 


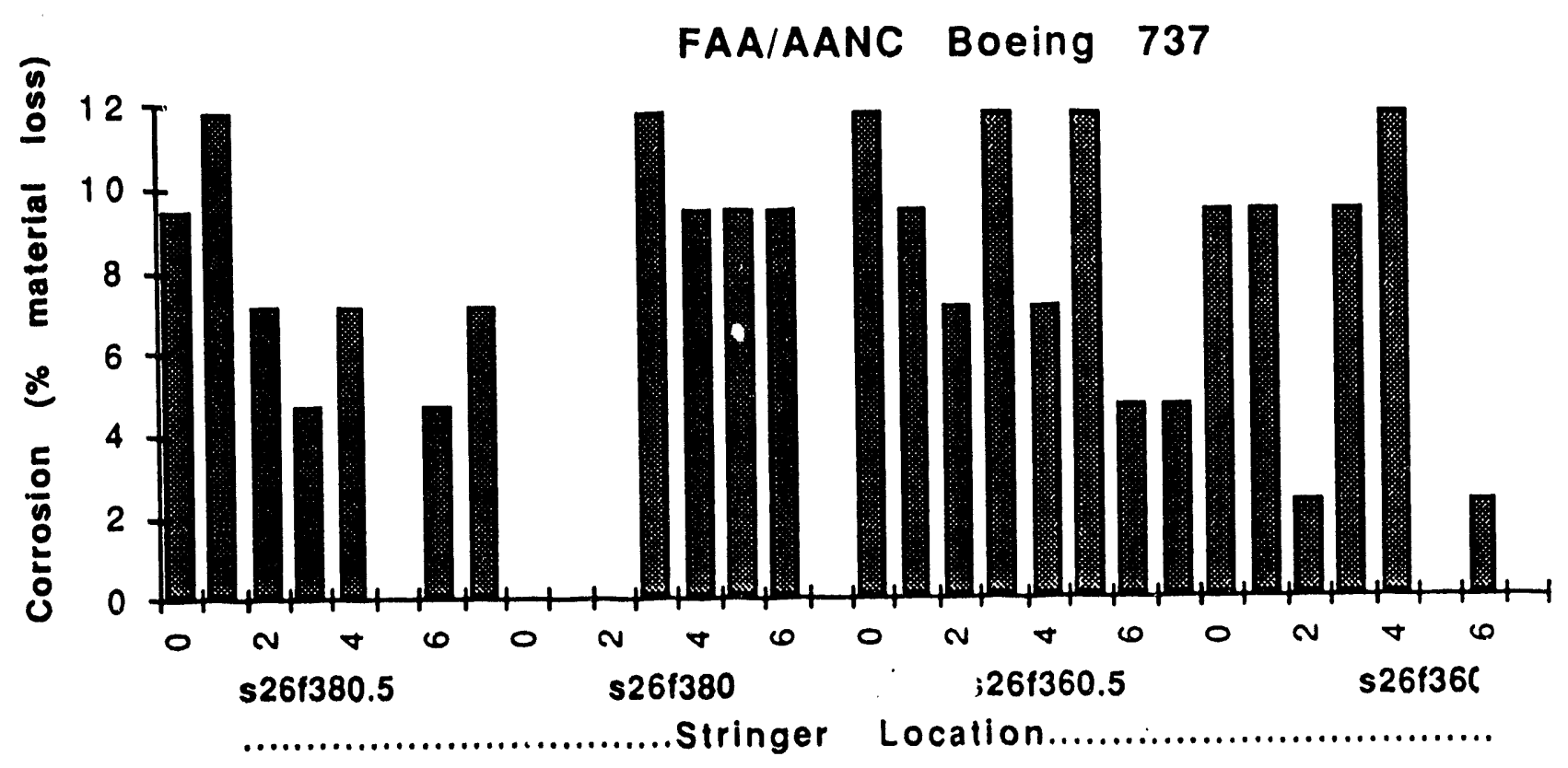

Figure 19. Percent material loss from corrosion, left to right of Stringer 26 images (centered from $50 \%$ aft of Station $\mathrm{f} 380$ to Station $\mathrm{f} 360$ ) relative to a cooler area with less material loss from corrosion. See Table 2 and Appendix B for spot locations where surface temperature differences were measured.

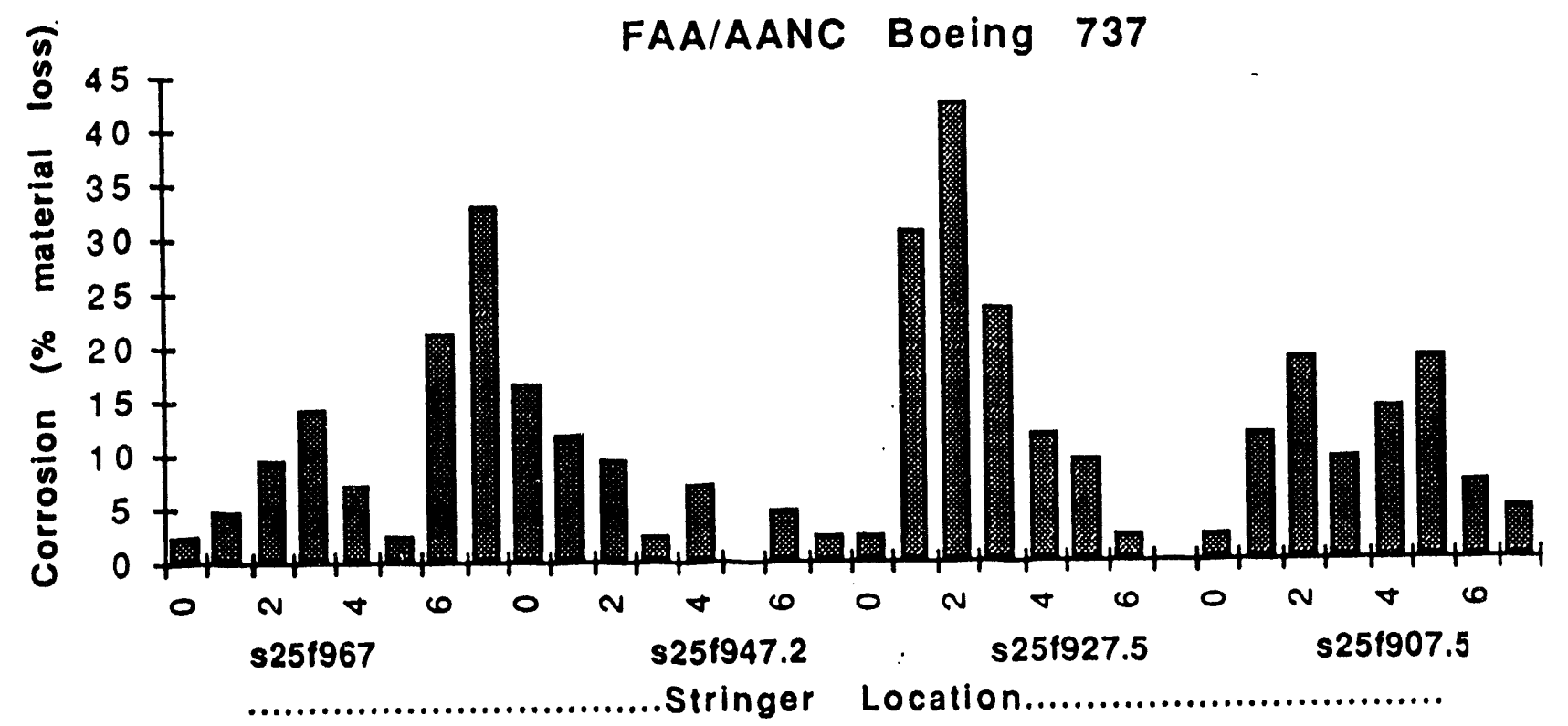

Figure 20. Percent material loss from corrosion, left to right of Stringer 25 images (centered from Station 1967, near the tail section, to $50 \%$ aft of Station $\mathrm{f} 60$ ) relative to a cooler area with less material loss from corrosion. Sec Table 3 and Appendix $B$ for spot locations where surface temperature differences were measured. 
Table 3. Measured $10 \mu \mathrm{m}$ IR temperature differences for FAA/AANC Boeing 737 Aircraft lap splice, Stringers 25 and 24 (see Appendix $A$ for photographs and Appendix $B$ for spot locations with relative temperature differences, $\Delta T$, in ${ }^{\circ} \mathrm{C}$, at $0.4 \mathrm{~s}$ after the heat flash, compared to a cooler site with less material loss from corrosion). We use the correlation of average material loss with above ambient surface temperature rise $0.4 \mathrm{~s}$ after the heat flash which averaged $24 \pm 5 \%$ per $1{ }^{\circ} \mathrm{C}$. The Stringer 25 tail section site, centered $50 \%$ aft of Station 1927 , where we found the most material loss (42 $\pm 9 \%$ ), may have been patched.

\begin{tabular}{|c|c|c|c|c|c|c|c|c|c|c|c|c|c|c|}
\hline Site & Spot & $\mathrm{T}$ & $\Delta T$ & $\%$ Corr & Site & Spot & $T$ & $\Delta \mathrm{T}$ & $\%$ Corr & Site & Spot & $T$ & $\Delta T$ & $\% \mathrm{Corr}$ \\
\hline $\begin{array}{c}s 25 \\
9667 \\
\max \% \\
33 \\
(7)\end{array}$ & $\begin{array}{l}0 \\
1 \\
2 \\
3 \\
4 \\
5 \\
6 \\
7\end{array}$ & $\begin{array}{l}28.9 \\
29.0 \\
29.2 \\
29.4 \\
29.1 \\
28.9 \\
29.7 \\
30.2\end{array}$ & $\begin{array}{l}0.1 \\
0.2 \\
0.4 \\
0.6 \\
0.3 \\
0.1 \\
0.9 \\
1.4\end{array}$ & $\begin{array}{c}2 \\
5 \\
9 \\
14 \\
7 \\
2 \\
21 \\
33\end{array}$ & $\begin{array}{c}s 25 \\
8887.5 \\
\\
\max \% \\
17 \\
(4)\end{array}$ & $\begin{array}{l}0 \\
1 \\
2 \\
3 \\
4 \\
5 \\
6 \\
7\end{array}$ & $\begin{array}{l}25.6 \\
25.6 \\
25.6 \\
25.9 \\
26.4 \\
26.4 \\
26.3 \\
25.9\end{array}$ & $\begin{array}{l}-0.1 \\
-0.1 \\
-0.1 \\
0.2 \\
0.7 \\
0.7 \\
0.6 \\
0.2\end{array}$ & $\begin{array}{c}\text { n.a. } \\
\text { n.a. } \\
\text { n.a. } \\
5 \\
17 \\
17 \\
14 \\
5\end{array}$ & $\begin{array}{c}\text { s24 } \\
\text { 1328 } \\
\\
\max \% \\
21 \\
(5)\end{array}$ & $\begin{array}{l}0 \\
1 \\
2 \\
3 \\
4 \\
5 \\
6 \\
7\end{array}$ & $\begin{array}{l}23.0 \\
23.1 \\
23.2 \\
23.3 \\
23.3 \\
23.5 \\
23.6 \\
23.9\end{array}$ & $\begin{array}{l}0.0 \\
0.1 \\
0.2 \\
0.3 \\
0.3 \\
0.5 \\
0.6 \\
0.9\end{array}$ & $\begin{array}{c}0 \\
2 \\
5 \\
7 \\
7 \\
12 \\
14 \\
21\end{array}$ \\
\hline $\begin{array}{c}s 25 \\
1947.2 \\
\max \% \\
17 \\
(4)\end{array}$ & $\begin{array}{l}0 \\
1 \\
2 \\
3 \\
4 \\
5 \\
6 \\
7 \\
\end{array}$ & $\begin{array}{l}28.3 \\
28.1 \\
28.0 \\
27.7 \\
27.9 \\
27.6 \\
27.8 \\
27.7 \\
\end{array}$ & $\begin{array}{l}0.7 \\
0.5 \\
0.4 \\
0.1 \\
0.3 \\
0.0 \\
0.2 \\
0.1 \\
\end{array}$ & $\begin{array}{l}17 \\
12 \\
9 \\
2 \\
7 \\
0 \\
5 \\
2 \\
\end{array}$ & $\begin{array}{c}\mathrm{s} 24 \\
\mathrm{~B} 60 \\
\\
\max \% \\
12 \\
(4)\end{array}$ & $\begin{array}{l}0 \\
1 \\
2 \\
3 \\
4 \\
5 \\
6 \\
7 \\
\end{array}$ & $\begin{array}{l}22.0 \\
22.0 \\
22.2 \\
22.1 \\
22.1 \\
22.4 \\
22.4 \\
22.5\end{array}$ & $\begin{array}{l}0.0 \\
0.0 \\
0.2 \\
0.1 \\
0.1 \\
0.4 \\
0.4 \\
0.5 \\
\end{array}$ & $\begin{array}{c}0 \\
0 \\
5 \\
2 \\
2 \\
9 \\
9 \\
12 \\
\end{array}$ & $\begin{array}{c}s 24 \\
1312.4 \\
\max \% \\
12 \\
(4)\end{array}$ & $\begin{array}{l}0 \\
1 \\
2 \\
3 \\
4 \\
5 \\
6 \\
7 \\
\end{array}$ & $\begin{array}{l}24.6 \\
25.1 \\
24.9 \\
25.1 \\
25.0 \\
25.1 \\
25.0 \\
25.2\end{array}$ & $\begin{array}{l}0.1 \\
0.4 \\
0.2 \\
0.4 \\
0.3 \\
0.4 \\
0.3 \\
0.5\end{array}$ & $\begin{array}{c}\text { n.a. } \\
9 \\
5 \\
9 \\
7 \\
9 \\
7 \\
12 \\
\end{array}$ \\
\hline $\begin{array}{c}s 25 \\
8927.5 \\
\max \% \\
42 \\
(9)\end{array}$ & $\begin{array}{l}0 \\
1 \\
2 \\
3 \\
4 \\
5 \\
6 \\
7 \\
\end{array}$ & $\begin{array}{l}28.9 \\
30.1 \\
30.6 \\
29.8 \\
29.3 \\
29.2 \\
28.9 \\
28.8 \\
\end{array}$ & $\begin{array}{l}0.1 \\
1.3 \\
1.8 \\
1.0 \\
0.5 \\
0.4 \\
0.1 \\
0.0 \\
\end{array}$ & $\begin{array}{c}2 \\
31 \\
42 \\
24 \\
12 \\
9 \\
2 \\
0 \\
\end{array}$ & $\begin{array}{c}s 24 \\
B 44.8 \\
\max \% \\
5 \\
(2)\end{array}$ & $\begin{array}{l}0 \\
1 \\
2 \\
3 \\
4 \\
5 \\
6 \\
7 \\
\end{array}$ & $\begin{array}{l}22.9 \\
22.8 \\
22.8 \\
22.8 \\
22.8 \\
22.8 \\
22.7 \\
22.7 \\
\end{array}$ & $\begin{array}{l}0.2 \\
0.1 \\
0.1 \\
0.1 \\
0.1 \\
0.1 \\
0.0 \\
0.0\end{array}$ & $\begin{array}{l}5 \\
2 \\
2 \\
2 \\
2 \\
2 \\
0 \\
0\end{array}$ & $\begin{array}{c}s 24 \\
\text { f294.5.8 } \\
\text { max \% } \\
12 \\
(4)\end{array}$ & $\begin{array}{l}0 \\
1 \\
2 \\
3 \\
4 \\
5 \\
6 \\
7 \\
\end{array}$ & $\begin{array}{l}24.6 \\
24.6 \\
24.6 \\
24.6 \\
24.6 \\
24.6 \\
24.9 \\
24.9 \\
\end{array}$ & $\begin{array}{l}0.2 \\
0.2 \\
0.2 \\
0.2 \\
0.2 \\
0.2 \\
0.5 \\
0.5 \\
\end{array}$ & $\begin{array}{c}5 \\
5 \\
5 \\
5 \\
5 \\
5 \\
12 \\
12 \\
\end{array}$ \\
\hline $\begin{array}{c}s 25 \\
5907.5 \\
\max \% \\
19 \\
(4)\end{array}$ & $\begin{array}{l}0 \\
1 \\
2 \\
3 \\
4 \\
5 \\
6 \\
7\end{array}$ & $\begin{array}{l}28.6 \\
29.0 \\
29.3 \\
28.9 \\
29.1 \\
29.3 \\
28.8 \\
28.7\end{array}$ & $\begin{array}{l}0.1 \\
0.5 \\
0.8 \\
0.4 \\
0.6 \\
0.8 \\
0.3 \\
0.2\end{array}$ & $\begin{array}{c}2 \\
12 \\
19 \\
9 \\
14 \\
19 \\
7 \\
5 \\
\end{array}$ & $\begin{array}{c}\$ 24 \\
\mathfrak{1} 328.5 \\
\max \% \\
9 \\
(3)\end{array}$ & $\begin{array}{l}0 \\
1 \\
2 \\
3 \\
4 \\
5 \\
6 \\
7\end{array}$ & $\begin{array}{l}28.7 \\
28.9 \\
20.6 \\
24.7 \\
23.8 \\
24.0 \\
23.9 \\
24.1\end{array}$ & $\begin{array}{r}5.0 \\
5.2 \\
-3.1 \\
1.0 \\
0.1 \\
0.3 \\
0.2 \\
0.4\end{array}$ & $\begin{array}{c}\text { n.a. } \\
\text { n.a. } \\
\text { n.a. } \\
\text { n.a. } \\
2 \\
7 \\
5 \\
9\end{array}$ & $\begin{array}{c}\mathrm{s} 24 \\
\text { f294.5.3 } \\
\max \% \\
9 \\
(3)\end{array}$ & $\begin{array}{l}0 \\
1 \\
2 \\
3 \\
4 \\
5 \\
6 \\
7\end{array}$ & $\begin{array}{l}23.9 \\
23.5 \\
24.0 \\
24.6 \\
24.6 \\
24.9 \\
24.8 \\
24.6\end{array}$ & $\begin{array}{l}-0.6 \\
-1.0 \\
-0.5 \\
0.1 \\
0.1 \\
0.4 \\
0.3 \\
0.1\end{array}$ & $\begin{array}{c}\text { n.a. } \\
\text { n.a. } \\
\text { n.a. } \\
2 \\
2 \\
9 \\
7 \\
2\end{array}$ \\
\hline
\end{tabular}




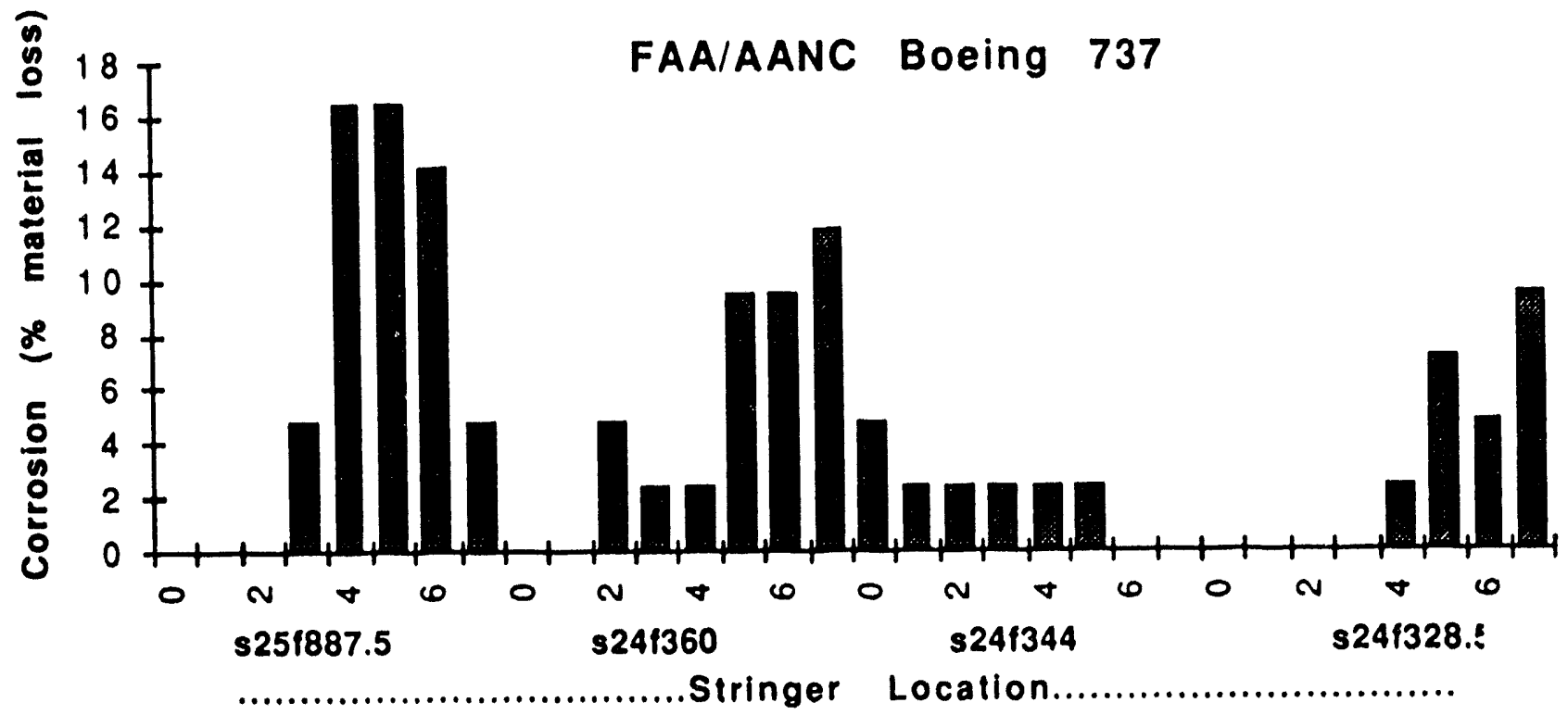

Figure 21. Percent material loss from corrosion, left to right of Stringer 25 images (centered $50 \%$ aft of Station 8887 , near the tail section) and Stringer 24 (centered from Station 360 to $50 \%$ aft of Station B28, near the nose section) relative to a conler area with less material loss from corrosion. See Table 3 and Appendix B for spot locations on color-ccded temperature maps.

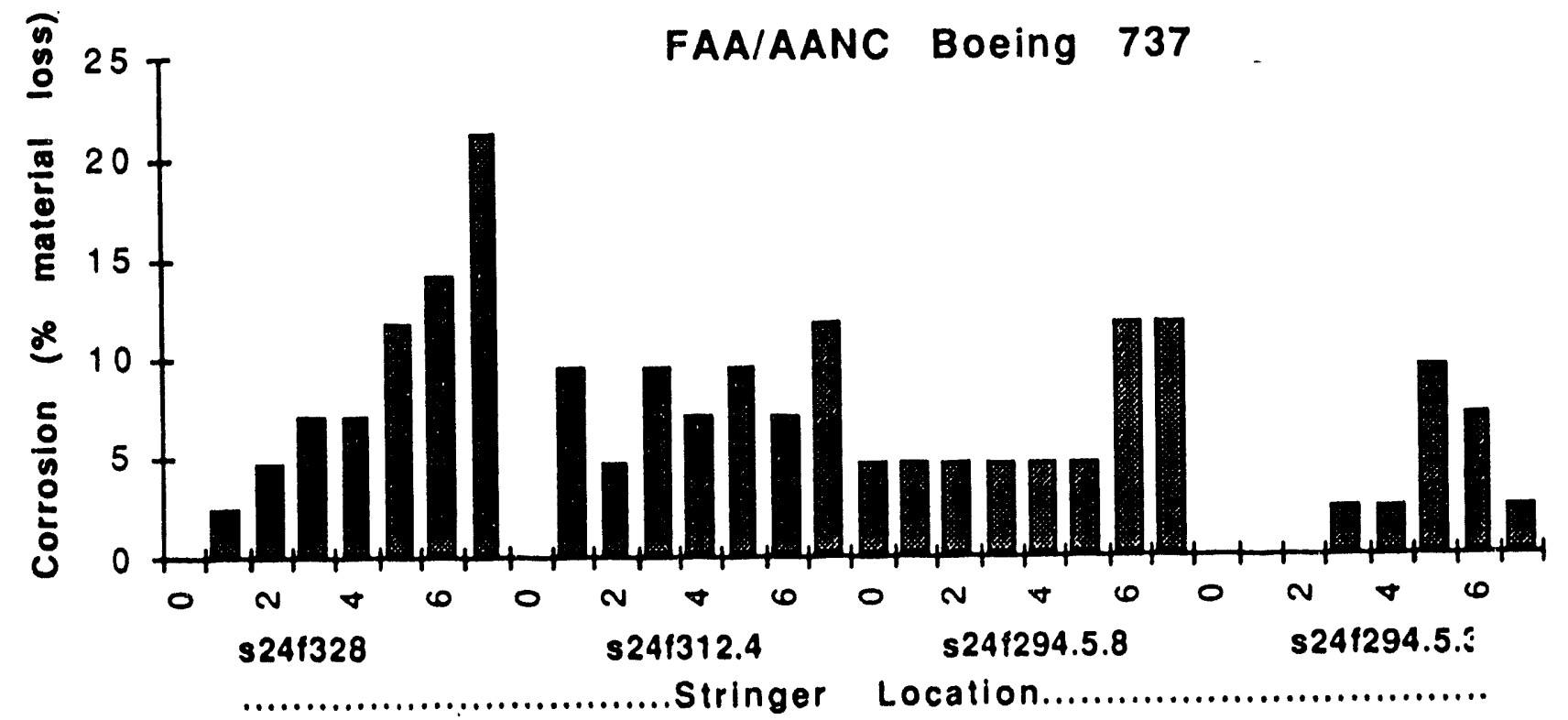

Figure 22. Percent material loss from corrosion, left w right of Stringer 24 images (centered from Station 328 to $30 \%$ aft of Station 2994.5, near the nose section) relative to a cooler area with less material loss from corrosion. See Table 3 and Appendix B for spot locations on color-coded temperature maps. 


\subsection{BOEING KC-135 AIRCRAFT PANELS: CORROSION TABLES}

Photographs of Inspection Panels Nos. 2-4 and End Panels Nos. 1-5 are shown facing the front surface, painted black, before and after the black paint was removed and facing the back surface (see Appendix A). Thickness measurements were taken at various locations and shown adjacent to the photographs (at top right).

The Agema 880 DBIR System recorded twenty-three 12 bit digital images scanned at $5 \mu \mathrm{m}$ and $10 \mu \mathrm{m}$ from flash-heated Tinker AFB Boeing KC-135 Inspection Panels 1-5. These images are shown at 0.4 seconds after the heat flash (see Appendix C). There were eight spots selected and an area box where surface temperatures were displayed. Also there were profiles of temperatures recorded at $10 \mu \mathrm{m}$ (in ${ }^{\circ} \mathrm{C}$ ). The correlation between the above ambient surface temperature and the percent material loss from corrosion was established using the corroded F-18 wing box structure and several aluminum plates with milled, flat-bottom holes (see Table 1 and Appendix A).

Tables 4 and 5 summarize our calculations for 8 spots on each panel or end piece, the locations of which are shown in Appendix C. The tables show the measured percent skin-thickness loss from corrosion relative to a site with the least corrosion for each image. Histogram charts of Table 4 data are shown (from left to right, at sites 0-7) with percent material loss relative to the minimum value. See Figures 23-25 respectively for Panels 2-4.

Table 4. Tinker KC-135 panel measurements (see Appendix A for photographs of Panels 2-4 and Appendix C for spot locations with relative temperature differences, $\Delta \mathrm{T}$, in ${ }^{\circ} \mathrm{C}$, at $0.4 \mathrm{~s}$, compared to a cooler site with less material loss from corrosion). We use the established average material loss of $23.6 \%$ per $1{ }^{\circ} \mathrm{C}$ surface temperature rise $0.4 \mathrm{~s}$ after the heat flash (see Appendix A).

\begin{tabular}{|c|c|c|c|c|c|c|c|c|c|c|c|c|c|c|}
\hline Panel & Spot & $\mathrm{T}$ & $\Delta \mathrm{T}$ & \%Corr & Panel & Spot & $\mathrm{T}$ & $\Delta \mathrm{T}$ & \%Corr & Panel & Spot & $\mathrm{T}$ & $\Delta \mathrm{T}$ & \%Corr \\
\hline $2 \mathrm{FL}$ & $\begin{array}{l}0 \\
1 \\
2 \\
3 \\
4 \\
5 \\
6 \\
7 \\
\end{array}$ & $\begin{array}{l}27.2 \\
27.6 \\
27.4 \\
27.4 \\
27.6 \\
27.4 \\
27.6 \\
27.4 \\
\end{array}$ & $\begin{array}{l}0.0 \\
0.4 \\
0.2 \\
0.2 \\
0.4 \\
0.2 \\
0.4 \\
0.2 \\
\end{array}$ & $\begin{array}{l}0 \\
9 \\
5 \\
5 \\
9 \\
5 \\
9 \\
5 \\
\end{array}$ & $3 \mathrm{FL}$ & $\begin{array}{l}0 \\
1 \\
2 \\
3 \\
4 \\
5 \\
6 \\
7 \\
\end{array}$ & $\begin{array}{l}28.5 \\
29.0 \\
27.8 \\
29.3 \\
27.8 \\
28.1 \\
28.0 \\
28.0 \\
\end{array}$ & $\begin{array}{l}1.0 \\
1.5 \\
0.3 \\
1.8 \\
0.3 \\
0.6 \\
0.5 \\
0.5 \\
\end{array}$ & $\begin{array}{c}24 \\
35 \\
7 \\
42 \\
7 \\
14 \\
12 \\
12 \\
\end{array}$ & $4 \mathrm{FL}$ & $\begin{array}{l}0 \\
1 \\
2 \\
3 \\
4 \\
5 \\
6 \\
7 \\
\end{array}$ & $\begin{array}{l}27.6 \\
27.7 \\
27.8 \\
28.0 \\
28.0 \\
27.8 \\
28.4 \\
27.4 \\
\end{array}$ & $\begin{array}{l}0.2 \\
0.3 \\
0.4 \\
0.6 \\
0.6 \\
0.4 \\
1.0 \\
0.0 \\
\end{array}$ & $\begin{array}{c}5 \\
7 \\
9 \\
14 \\
14 \\
9 \\
24 \\
0 \\
\end{array}$ \\
\hline $2 \mathrm{fC}$ & $\begin{array}{l}0 \\
1 \\
2 \\
3 \\
4 \\
5 \\
6 \\
7 \\
\end{array}$ & $\begin{array}{l}29.2 \\
29.3 \\
28.9 \\
28.0 \\
28.7 \\
28.8 \\
28.4 \\
27.4 \\
\end{array}$ & $\begin{array}{l}.0 \\
2.1 \\
1.7 \\
0.8 \\
1.5 \\
1.6 \\
1.2 \\
0.2 \\
\end{array}$ & $\begin{array}{l}47 \\
50 \\
40 \\
19 \\
35 \\
38 \\
28 \\
5 \\
\end{array}$ & $3 \mathrm{FLC}$ & $\begin{array}{l}0 \\
1 \\
2 \\
3 \\
4 \\
5 \\
6 \\
7 \\
\end{array}$ & $\begin{array}{l}30.0 \\
30.4 \\
29.8 \\
29.5 \\
29.4 \\
29.1 \\
29.7 \\
28.7 \\
\end{array}$ & $\begin{array}{l}2.5 \\
2.9 \\
2.3 \\
2.0 \\
1.9 \\
1.6 \\
2.2 \\
1.2 \\
\end{array}$ & $\begin{array}{l}59 \\
68 \\
54 \\
47 \\
45 \\
38 \\
52 \\
28 \\
\end{array}$ & 4FLC & $\begin{array}{l}0 \\
1 \\
2 \\
3 \\
4 \\
5 \\
6 \\
7 \\
\end{array}$ & $\begin{array}{l}27.9 \\
28.0 \\
28.3 \\
28.2 \\
28.3 \\
27.9 \\
28.8 \\
28.0 \\
\end{array}$ & $\begin{array}{l}0.5 \\
0.6 \\
0.9 \\
0.8 \\
0.9 \\
0.5 \\
1.4 \\
0.6 \\
\end{array}$ & $\begin{array}{l}12 \\
14 \\
21 \\
19 \\
? 1 \\
12 \\
33 \\
14 \\
\end{array}$ \\
\hline 2FRC & $\begin{array}{l}0 \\
1 \\
2 \\
3 \\
4 \\
5 \\
6 \\
7 \\
\end{array}$ & $\begin{array}{l}30.1 \\
29.6 \\
29.1 \\
29.1 \\
29.2 \\
29.2 \\
28.4 \\
27.9 \\
\end{array}$ & $\begin{array}{l}2.9 \\
2.4 \\
1.9 \\
1.9 \\
2.0 \\
2.0 \\
1.2 \\
0.7 \\
\end{array}$ & $\begin{array}{l}68 \\
57 \\
45 \\
45 \\
47 \\
47 \\
28 \\
17 \\
\end{array}$ & $3 \mathrm{fRC}$ & $\begin{array}{l}0 \\
1 \\
2 \\
3 \\
4 \\
5 \\
6 \\
7 \\
\end{array}$ & $\begin{array}{l}27.9 \\
28.2 \\
27.9 \\
27.6 \\
28.3 \\
27.6 \\
28.5 \\
27.5 \\
\end{array}$ & $\begin{array}{l}0.4 \\
0.7 \\
0.4 \\
0.1 \\
0.8 \\
0.1 \\
1.0 \\
0.0 \\
\end{array}$ & $\begin{array}{c}9 \\
17 \\
9 \\
2 \\
19 \\
2 \\
24 \\
0 \\
\end{array}$ & 4FRC & $\begin{array}{l}0 \\
1 \\
2 \\
3 \\
4 \\
5 \\
6 \\
7 \\
\end{array}$ & $\begin{array}{l}29.3 \\
29.2 \\
28.8 \\
28.7 \\
28.5 \\
28.3 \\
29.2 \\
28.2 \\
\end{array}$ & $\begin{array}{l}1.9 \\
1.8 \\
1.4 \\
1.3 \\
1.1 \\
0.9 \\
1.8 \\
0.8 \\
\end{array}$ & $\begin{array}{l}45 \\
42 \\
33 \\
31 \\
26 \\
21 \\
42 \\
19 \\
\end{array}$ \\
\hline $2 \mathrm{FR}$ & $\begin{array}{l}0 \\
1 \\
2 \\
3 \\
4 \\
5 \\
6 \\
7 \\
\end{array}$ & $\begin{array}{l}28.7 \\
28.4 \\
27.8 \\
28.7 \\
29.1 \\
29.0 \\
28.1 \\
28.5\end{array}$ & $\begin{array}{l}1.5 \\
1.2 \\
0.6 \\
1.5 \\
1.9 \\
1.8 \\
0.9 \\
1.3 \\
\end{array}$ & $\begin{array}{l}35 \\
28 \\
14 \\
35 \\
45 \\
42 \\
21 \\
31 \\
\end{array}$ & $3 \mathrm{FR}$ & $\begin{array}{l}0 \\
1 \\
2 \\
3 \\
4 \\
5 \\
6 \\
7 \\
\end{array}$ & $\begin{array}{l}29.3 \\
28.7 \\
28.3 \\
28.9 \\
28.6 \\
29.1 \\
29.4 \\
28.1 \\
\end{array}$ & $\begin{array}{l}1.8 \\
1.2 \\
0.8 \\
1.4 \\
1.1 \\
1.6 \\
1.9 \\
0.6\end{array}$ & $\begin{array}{l}42 \\
28 \\
19 \\
33 \\
26 \\
38 \\
45 \\
14 \\
\end{array}$ & 4FR & $\begin{array}{l}0 \\
1 \\
2 \\
3 \\
4 \\
5 \\
6 \\
7 \\
\end{array}$ & $\begin{array}{l}29.6 \\
29.4 \\
29.2 \\
29.3 \\
28.5 \\
28.9 \\
29.5 \\
28.1\end{array}$ & $\begin{array}{l}2.2 \\
2.0 \\
1.8 \\
1.9 \\
1.1 \\
1.5 \\
2.1 \\
0.7\end{array}$ & $\begin{array}{l}52 \\
47 \\
42 \\
45 \\
26 \\
35 \\
50 \\
17 \\
\end{array}$ \\
\hline
\end{tabular}




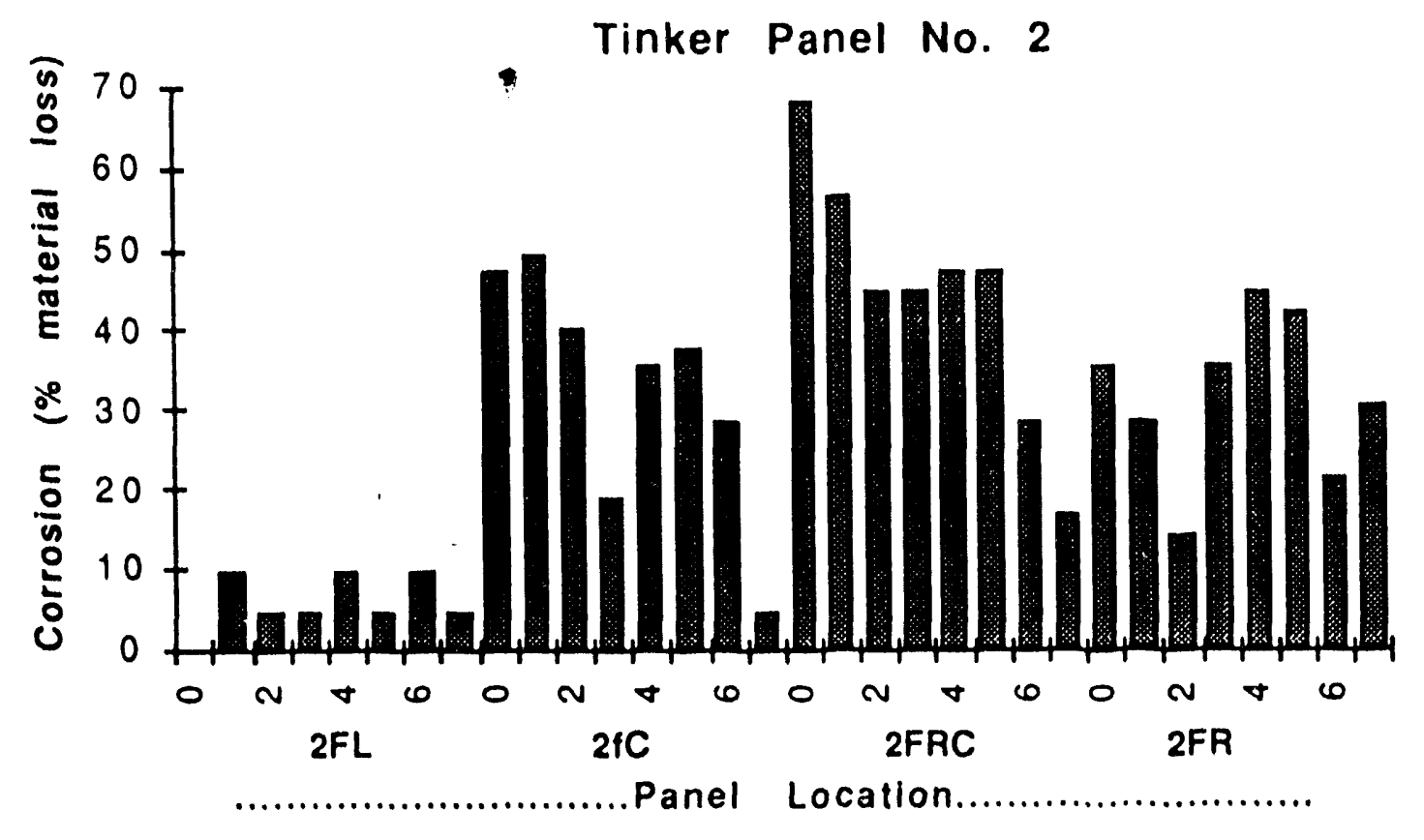

Figure 23. Percent material loss from corrosion, left to right of Panel 2, relative to a cooler area with less material loss from corrosion. See Appendix C for spot locations where surface temperature differences were mcasured.

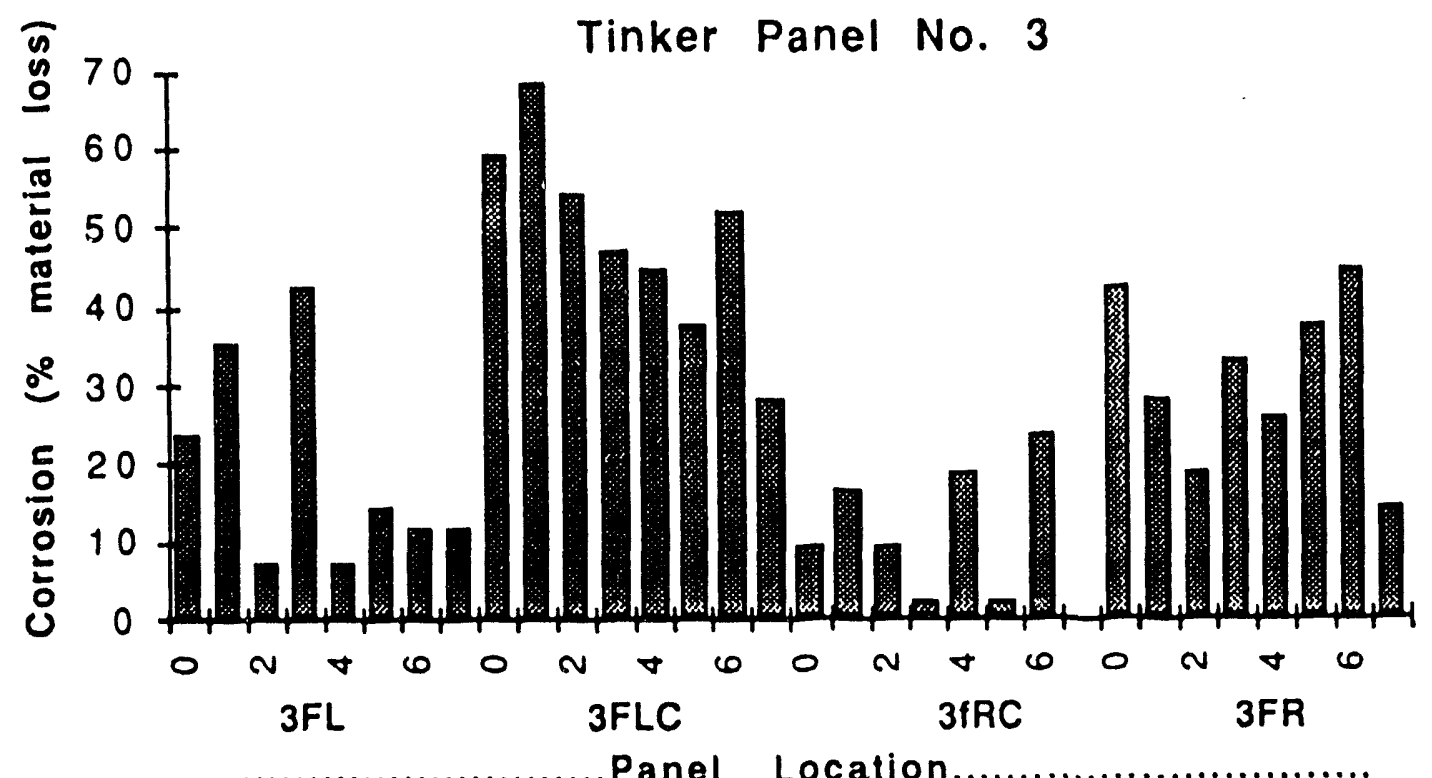

Figure 24. Percent material loss from corrosion, left to right of Panel 3, relative to a cooler area with less material loss from corrosion. See Appendix C for spot locations where surface temperature differences were mcasured. 


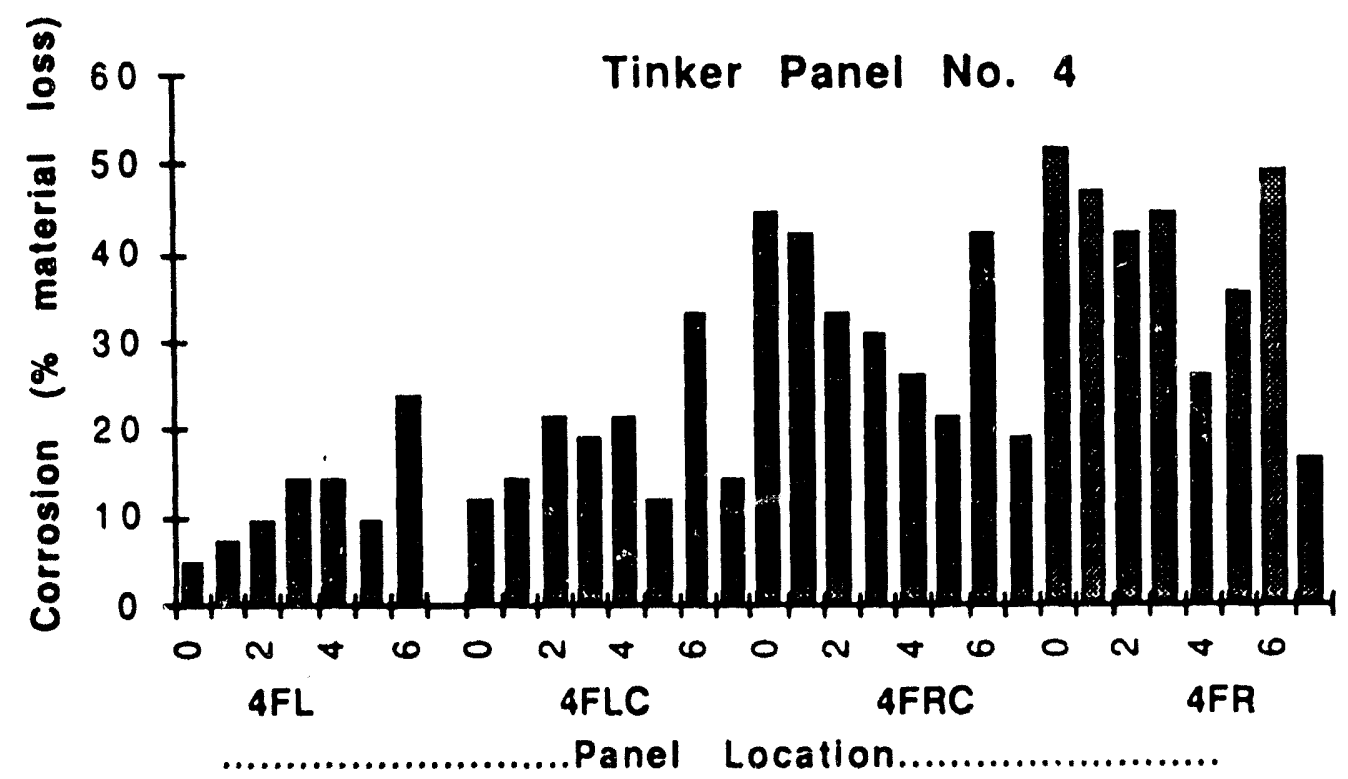

Figure 25. Percent material loss from corrosion, left to right of Panel 4, relative to a cooler area with less material loss from corrosion. See . ippendix $C$ for spot locations where surface temperature differences were measured.

\subsection{SUMMARY AND CONCLUSION}

We applied dual-band infrared imaging for wide area inspection of a Bocing 737 aircraft owned by the AANC. Sandia in Albuquerque, NM and several Bocing KC-135 aircraft panels used for the round robin experiment at Tinker AFB, OK. We analyzed selective DBIR image ratios which enhance surface temperature contrast and remove surface-emissivity clutter (from dirt, dents, tape, markings, ink, sealants, uneven paint, paint stripper, exposed metal and roughness variations).

We established the correlation of percent thickness loss with surface temperature rise (above ambient) for a flash-healed, partially corroded F-18 wing box structure (with a $2.9 \mathrm{~mm}$ uncorroded thickness) and several aluminum reference panels (with 1.0, 1.1. 2.3 and $3.9 \mathrm{~mm}$ thicknesses) which had 6 to $60 \%$ thickness losses at milled flat-bottom hole sites. Based on this correlation, lap splice temperatures rise $1^{\circ} \mathrm{C}$ per $24 \pm 5 \%$ material loss at $0.4 \mathrm{~s}$ after the heat flash. Corrosion by-products played a negligible role compared to the $21 \%$ experimental errors associated with different thickness calibration panels.

By recording 12 bit digital images, we had flexibility to scale the image data for an extended temperature range (suitable for extensive corrosive activity) or to resolve small temperature differences for a nartow range (suitable for minimal corrosive activity). By recording thickness-loss effects related to surface temperature increases at $0.4 \mathrm{~s}$ after the heat flash, we avoided the late time masking effect of disbonds which delay heat uransfer from the front to the back surface (e.g., for the Boeing 737).

Thermal ineria maps depicted bulk thermal property effects while minimizing nonuniformities in the heat source. Late time thermal inertia maps (at 1.6 to $8.0 \mathrm{~s}$ for the Boeing 737 and 0.4 to $4.0 \mathrm{~s}$ for the Boeing KC-135) depicted lap splice sites with corrosion-related material losses which had less resistance to temperature change than their surroundings.

The Boeing 737 Aircraft fuselage lap splices had corrosion-related thickness losses (relative to the least corroded site per image) typically from as low as $2 \pm 2 \%$ to as high as $42 \pm 9 \%$; whereas, the Boeing KC-135 Inspection Panel lap splice thickness tosses ranged from $2 \pm 2 \% 1068 \pm 14 \%$. We note an exceptional case: the left a.d right (overlapping) images of the left end piece for Panel 5 , in Table 5 , with $\sim 100 \%$ corrosion. In this case, corrosion appears to have made an area of very low conductivity (e.g., air within a hole, which was covered up by tape) where we measured a $44 \pm 6^{\circ} \mathrm{C}$ above ambient surface temperature rise at $0.4 \mathrm{~s}$ after the heat nash. 
Table 5. Tinker KC-135 panel end piece measurements (see Appendix A for photographs of the end pieces for Panels $1-5$ and Appendix $B$ for spot locations with relative temperature differences, $\Delta \mathrm{T}$, in ${ }^{\circ} \mathrm{C}$, at $0.4 \mathrm{~s}$, compared to a cooler site with less material loss from corrosion). We used the established average material loss of $23.6 \%$ per $1^{\circ} \mathrm{C}$ surface temperature rise, $0.4 \mathrm{~s}$ after the heat flash (see Appendix C).

\begin{tabular}{|c|c|c|c|c|c|c|c|c|c|c|c|c|c|c|}
\hline Panel & Spot & $\mathrm{T}$ & $\Delta \mathrm{T}$ & \%Corr & Panel & Spot & $\mathrm{T}$ & $\Delta \mathrm{T}$ & $\%$ Corr & Panel & Spot & $\mathrm{T}$ & $\Delta \mathrm{T}$ & $\%$ Corr \\
\hline 1LF & $\begin{array}{l}0 \\
1 \\
2 \\
3 \\
4 \\
5 \\
6 \\
7 \\
\end{array}$ & $\begin{array}{l}29.8 \\
30.3 \\
30.5 \\
30.1 \\
29.7 \\
29.7 \\
29.5 \\
29.3 \\
\end{array}$ & $\begin{array}{l}0.8 \\
1.3 \\
1.5 \\
1.1 \\
0.7 \\
0.7 \\
0.5 \\
0.3 \\
\end{array}$ & $\begin{array}{c}19 \\
31 \\
35 \\
26 \\
17 \\
17 \\
12 \\
7\end{array}$ & $3 \mathrm{LF}$ & $\begin{array}{l}0 \\
1 \\
2 \\
3 \\
4 \\
5 \\
6 \\
7 \\
\end{array}$ & $\begin{array}{l}27.8 \\
27.8 \\
27.6 \\
28.8 \\
28.3 \\
28.1 \\
27.5 \\
28.0\end{array}$ & $\begin{array}{l}0.3 \\
0.3 \\
0.1 \\
1.3 \\
0.8 \\
0.6 \\
0.0 \\
0.5\end{array}$ & $\begin{array}{c}7 \\
7 \\
2 \\
31 \\
19 \\
14 \\
0 \\
12\end{array}$ & 5IfL & $\begin{array}{l}0 \\
1 \\
2 \\
3 \\
4 \\
5 \\
6 \\
7 \\
\end{array}$ & $\begin{array}{l}69.2 \\
30.4 \\
30.4 \\
30.7 \\
30.5 \\
30.0 \\
29.5 \\
29.5\end{array}$ & $\begin{array}{l}40.2 \\
1.4 \\
1.4 \\
1.7 \\
1.5 \\
1.0 \\
0.5 \\
0.5\end{array}$ & $\begin{array}{c}-100 \\
33 \\
33 \\
40 \\
35 \\
24 \\
12 \\
12\end{array}$ \\
\hline IRF & $\begin{array}{l}0 \\
1 \\
2 \\
3 \\
4 \\
5 \\
6 \\
7 \\
\end{array}$ & $\begin{array}{l}29.5 \\
29.0 \\
29.2 \\
29.5 \\
29.3 \\
29.7 \\
29.4 \\
29.2 \\
\end{array}$ & $\begin{array}{l}0.5 \\
0.0 \\
0.2 \\
0.5 \\
0.3 \\
0.7 \\
0.4 \\
0.2 \\
\end{array}$ & $\begin{array}{c}12 \\
0 \\
5 \\
12 \\
7 \\
17 \\
9 \\
5 \\
\end{array}$ & $3 \mathrm{RF}$ & $\begin{array}{l}0 \\
1 \\
2 \\
3 \\
4 \\
5 \\
6 \\
7 \\
\end{array}$ & $\begin{array}{l}28.2 \\
29.0 \\
29.1 \\
28.7 \\
28.0 \\
28.9 \\
29.1 \\
28.5 \\
\end{array}$ & $\begin{array}{l}0.5 \\
1.3 \\
1.4 \\
1.0 \\
0.3 \\
1.2 \\
1.4 \\
0.8 \\
\end{array}$ & $\begin{array}{c}12 \\
31 \\
33 \\
24 \\
7 \\
28 \\
33 \\
19 \\
\end{array}$ & SIfR & $\begin{array}{l}0 \\
1 \\
2 \\
3 \\
4 \\
5 \\
6 \\
7 \\
\end{array}$ & $\begin{array}{l}75.9 \\
30.4 \\
30.0 \\
29.8 \\
29.7 \\
29.4 \\
29.5 \\
29.3 \\
\end{array}$ & $\begin{array}{c}46.9 \\
1.4 \\
1.0 \\
0.8 \\
0.7 \\
0.4 \\
0.5 \\
0.3 \\
\end{array}$ & $\begin{array}{c}-100 \\
33 \\
24 \\
19 \\
17 \\
9 \\
12 \\
7 \\
\end{array}$ \\
\hline $2 \mathrm{LF}$ & $\begin{array}{l}0 \\
1 \\
2 \\
3 \\
4 \\
5 \\
6 \\
7\end{array}$ & $\begin{array}{l}29.7 \\
29.6 \\
29.5 \\
29.7 \\
29.5 \\
29.4 \\
29.6 \\
29.7 \\
\end{array}$ & $\begin{array}{l}0.5 \\
0.4 \\
0.3 \\
0.5 \\
0.3 \\
0.2 \\
0.4 \\
0.5 \\
\end{array}$ & $\begin{array}{c}12 \\
9 \\
7 \\
12 \\
7 \\
5 \\
9 \\
12 \\
\end{array}$ & 4LF & $\begin{array}{l}0 \\
1 \\
2 \\
3 \\
4 \\
5 \\
6 \\
7 \\
\end{array}$ & $\begin{array}{l}29.1 \\
28.8 \\
28.7 \\
28.9 \\
28.9 \\
28.8 \\
29.1 \\
29.1 \\
\end{array}$ & $\begin{array}{l}1.0 \\
0.7 \\
0.6 \\
0.8 \\
0.8 \\
0.7 \\
1.0 \\
1.0\end{array}$ & $\begin{array}{l}24 \\
17 \\
14 \\
19 \\
19 \\
17 \\
24 \\
24 \\
\end{array}$ & $5 \mathrm{RF}$ & $\begin{array}{l}0 \\
1 \\
2 \\
3 \\
4 \\
5 \\
6 \\
7 \\
\end{array}$ & $\begin{array}{l}29.5 \\
30.2 \\
30.0 \\
29.5 \\
29.5 \\
30.6 \\
30.6 \\
30.3 \\
\end{array}$ & $\begin{array}{l}0.3 \\
1.0 \\
0.8 \\
0.3 \\
0.3 \\
1.4 \\
1.4 \\
1.1 \\
\end{array}$ & $\begin{array}{c}7 \\
24 \\
19 \\
7 \\
7 \\
33 \\
33 \\
26 \\
\end{array}$ \\
\hline 2RF & $\begin{array}{l}0 \\
1 \\
2 \\
3 \\
4 \\
5 \\
6 \\
7\end{array}$ & $\begin{array}{l}30.8 \\
29.9 \\
29.3 \\
29.8 \\
29.4 \\
30.0 \\
29.3 \\
29.1\end{array}$ & $\begin{array}{l}1.7 \\
0.8 \\
0.2 \\
0.7 \\
0.3 \\
0.9 \\
0.2 \\
0.0\end{array}$ & $\begin{array}{c}40 \\
19 \\
5 \\
17 \\
7 \\
21 \\
5 \\
0\end{array}$ & 4RF & $\begin{array}{l}0 \\
1 \\
2 \\
3 \\
4 \\
5 \\
6 \\
7\end{array}$ & $\begin{array}{l}28.7 \\
28.3 \\
28.2 \\
28.9 \\
29.1 \\
28.3 \\
28.4 \\
28.1\end{array}$ & $\begin{array}{l}0.7 \\
0.3 \\
0.2 \\
0.9 \\
1.1 \\
0.3 \\
0.4 \\
0.1\end{array}$ & $\begin{array}{c}17 \\
7 \\
5 \\
21 \\
26 \\
7 \\
9 \\
2\end{array}$ & $\operatorname{pan} P$ & $\begin{array}{l}0 \\
1 \\
2 \\
3 \\
4 \\
5 \\
6 \\
7\end{array}$ & $\begin{array}{l}27.6 \\
29.2 \\
28.1 \\
27.7 \\
27.6 \\
29.2 \\
27.9 \\
27.7\end{array}$ & $\begin{array}{l}0.1 \\
1.7 \\
0.6 \\
0.2 \\
0.1 \\
1.7 \\
0.4 \\
0.2\end{array}$ & $\begin{array}{c}2 \\
40 \\
14 \\
5 \\
2 \\
40 \\
9 \\
5\end{array}$ \\
\hline
\end{tabular}

\subsection{ACKNOWLEDGEMENTS}

This work was performed by LLNL under the auspices of DOE contract number W-7405-ENG-48 for the FAA Aging Aircraft Non-Destructive Inspection R\&D Program, Interagency Agreement DTFA03-92-A-00007. We thank Chris Seher, P. K. Bhagat and David Galella at the FAA Technical Center for their helpful suggestions. We acknowledge the support efforts of Gary Phipps, Craig Jones, Don Harmon and Pat Walter at AANC, Sandia National Laboratory, Albuquerque, NM. Also, we are grateful for the special efforts by Don Nieser and Deric Kraxberger at Tinker AFB, OK for providing the Boeing KC-135 Panels, used for the round robin experiment, to LLNL for our DBIR imaging inspections. We appreciate Maurice Bales and Chip Bishop, Bales Scientific Inc., for the loan of calibration panels obtained from Delta Airlines and for their support demonstrating the Bales DBIR Imaging System and NDI Workstation at the FAAAANC hangar in Albuquerque and Owen Manning, Northrop Corporation, for the loan of a corroded F-18 wing box structure. We credit our colleague and research consultant, Professor Vladimir Vavilov, from the Tomsk Research Institute of Nondestructive Testing, Tomsk, Russia with the concept "dynamic thermal tomography". We acknowledge the support of Dr. Satish Kulkarni, Engineering Sciences Division, NDE Section Leader at LLNL. 


\subsection{REFERENCES}

1. N. Del Grande, "Airborne and Field Temperature Surveys Compared At Long Valley KGRA, California", Geothermal Resources Council Transactions 571 (1978).

2. N. K. Del Grande, "Airborne Temperature Survey Maps of Heat Flow Anomalies for Exploration Geology", Proceeding of International Symposium on Remote Sensing of Environment. Second Thematic Conference on Remote Sensing for Exploration Geology Dec. 1982. Reprinted in Geothermal Resources Council Bulletin 14, p.3, Mar. 1985.

3. N. K. Del Grande, G. A. Clark, P. F. Durbin, D. J. Fields, J. E. Hernandez and R. J. Sherwood, "Buried Object Remote Detection For Law Enforcement", Surveillance Technologies, SPIE Vol. 1479, 335 (1991).

4. N. K. Del Grande, "Temperature Evaluated Mine Position Survey (TEMPS) Application of Dual Band Infrared Methodology", Proceedings of the 1990 Meeting of the IRIS Specialty Group on Passive Sensors, IRIA/ERIM sponsored symposium, March 1990.

5. N. K. Del Grande, "Sensor Fusion Methodology for Remote Detection of Buried Land Mines", Proceedings of the 3rd National Symposium on Sensor Fusion, Orlando, Fl, Vol. 1, IIAC/ERIM, p.407, August 1990.

6. Nancy Del Grande, "Airborne Detection Of Buried Minefields", Energy and Technology Review, University of Califormia LLNL Report, UCRL-52000-91-12, (1991).

7. N. K. Del Grande, P. F. Durbin, M. R. Gorvad, D. E. Perkins, G. A. Clark, J. E. Hernandez and R. J. Sherwood, "Dualband Infrared Capabilities for Imaging Buried Object Sites" in Proceedings of SPIE Conference 1942: Underground and Obscured Object Imaging and Detection, Ed. Nancy Del Grande, Ivan Cindrich and Peter Johnson, Orlando FL (1993).

8. G. A. Clark, J. E. Hernandez, S. K. Sengupta, R. J. Sherwood, P. C. Schaich, M. R. Buhl, R. J. Kane, M. J. Barth, N. K. Del Grande, "Sensor Feature Fusion for Detecting Buried Objects", Proceedings of SPIE Conference 1942: Underground and Obscured Object Imaging and Detection, Ed. Nancy Del Grande, Ivan Cindrich and Peter Johnson, Orlando FL (1993).

9. N. K. Del Grande, P. F. Durbin and D. E. Perkins, "Dual-Band Infrared Imaging Applications: Locating Buried Minefields, Mapping Sea Ice, And Inspecting Aging Aircraft", Review of Progress in Quantitative Nondestructive Evaluation. Ed. D. O. Thompson and D. E. Chimenti, Plenum Pr. NY, 12A, 465-472, 1993.

10. John E. Lewis, Nancy Del Grande, Ian McKendry, Philip Durbin and Matti Lepparanta, "Thermal Mapping" in ERS-1 Baltic Sea Ice Calibration/Validation Post-Experiment Report / Piper/Finland, Finnish Institute of Marine Research Report 1992 (9), Ed. Matti Lepparanta and Mikko Lensu, Helsinki (1992).

11. P.F. Durbin, N.K. Del Grande, K.W. Dolan, D.E. Perkins and A.B. Shapiro, "Dual-Band Infrared Thermography for Quantitative Nondestructive Evaluation" Joint Army, Navy, NASA. Air Force (JANNAF) NDE Subcommittee Meeting Proceedings, Apr. 1993.

12. N. K. Del Grande, K. W. Dolan, P. F. Durbin, M. R. Gorvad, B. T. Kornblum, D. E. Perkins, D. J. Schneberk and A. B. Shapiro, "Three-Dimensional Dynamic Thermal Imaging of Structural Flaws by Dual-band Infrared Computed Tomography" in Proceedings of SPIE Conference 1942: Underground and Obscured Object Imaging and Detection, Ed. Nancy Del Grande, Ivan Cindrich and Peter Johnson, Orlando FL (1993).

13. L. A. LeSchack and N. K. Del Grande, "A Dual-Wavelength Thermal Infrared Scanner As A Potential Airborne Geophysical Exploration Tool", Geophysics 41, 1318 (1976).

14. H. S. Carslaw and J. C. Jaeger, Conduction of Heat in Solids, 2nd Edition, Oxford Univ. Pr., London, p. 259, 1980.

15. Arthur B. Shapiro, "TOPAZ - A three-dimensional finite element heat transfer code, Lawrence Livermore Laboratory Reporn UCID-20484 August 1985. 


\section{APPENDIX A: PHOTOGRAPHS OF HANGAR SETUP AND TEST PANELS}

We show photographs of:

- the Boeing 737 aircraft owned by the FAAVAANC and housed at the Sandia Albuquerque hangar where we conducted our demonstration of dual-band infrared imaging to locate hidden defects;

- the Tinker AFB Panels removed from the Bocing KC-135 aircraft which were brought to LLNL where we conducted our corrosion studies;

- the corroded F-18 wing box structure used to establish the correlation between surface temperature rise, above the ambient temperature, and thickness loss associated with corrosion;

- one of the aluminum plates with milled flat bottom holes used to establish the corrclation betwecn surface tcmperature rise, above the ambient temperature and thickness loss from a milled, nat-bottom hole. 


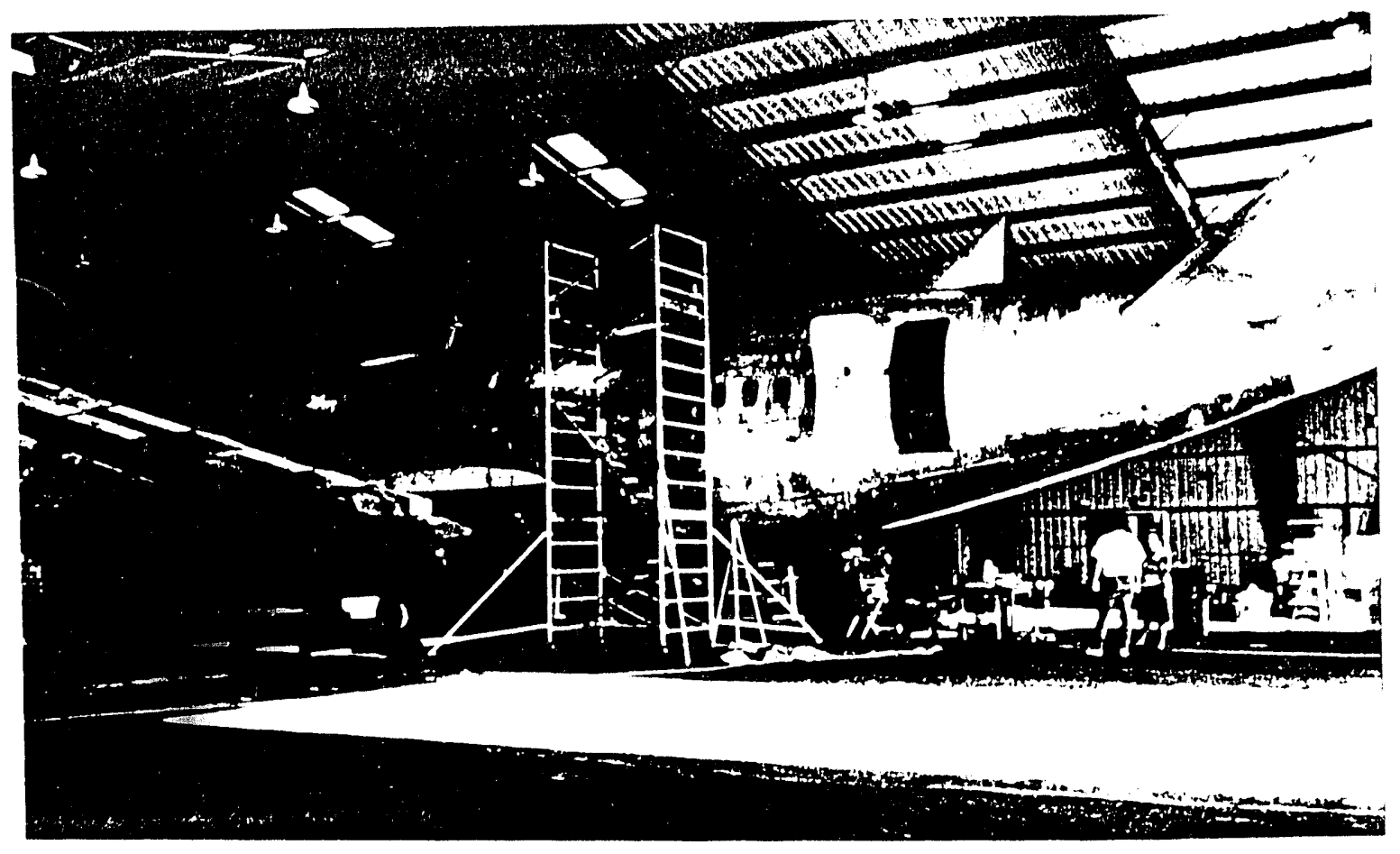

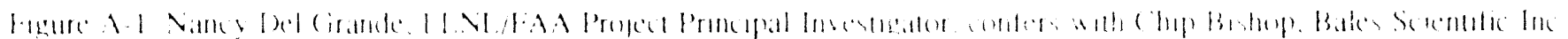

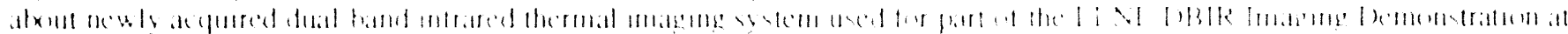

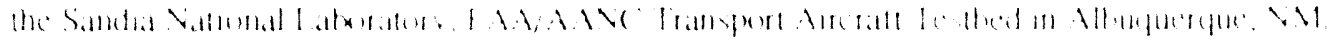

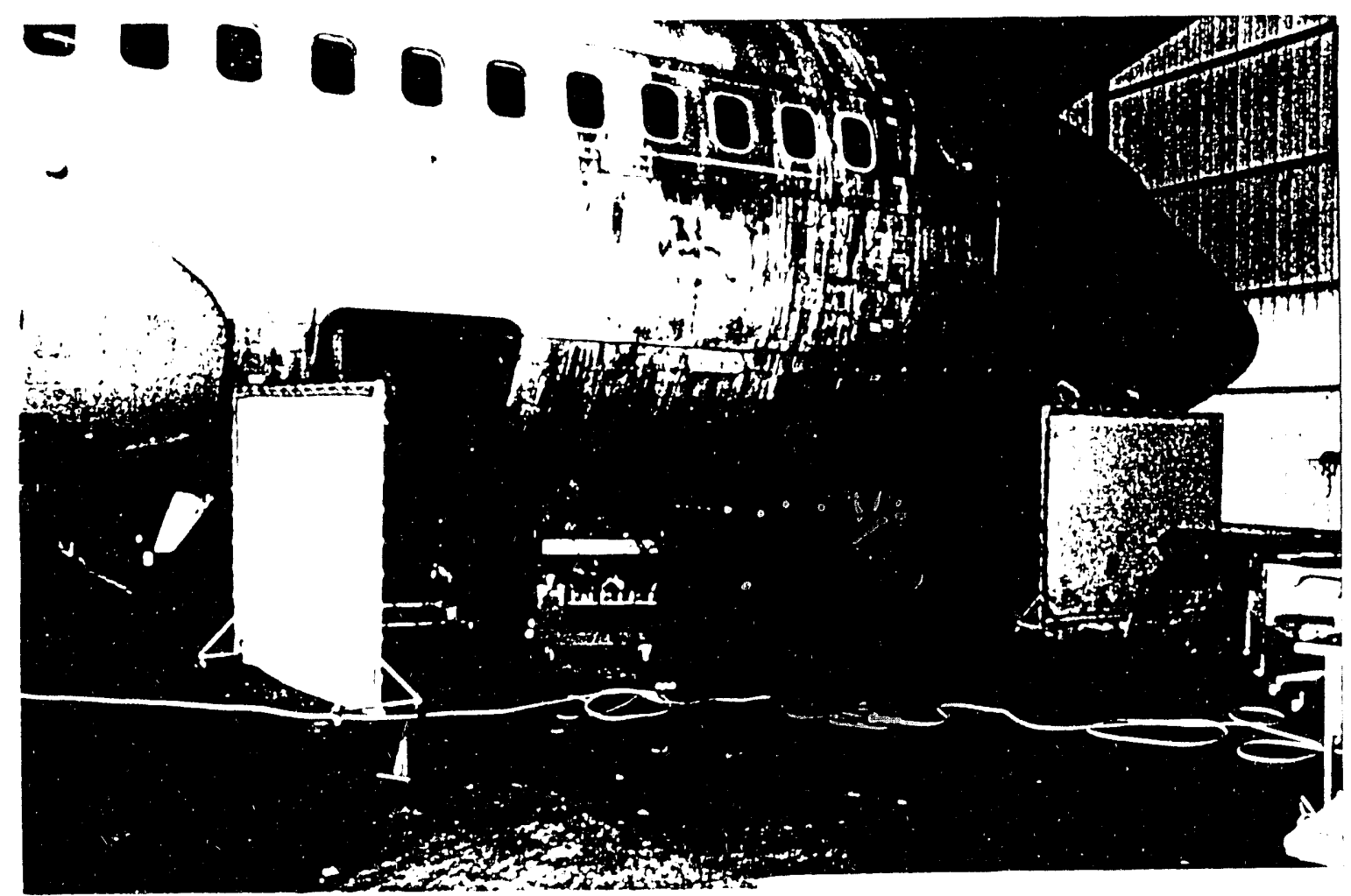

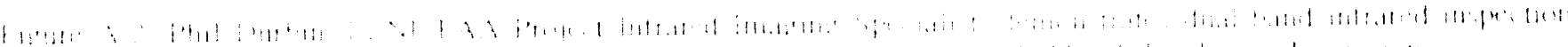

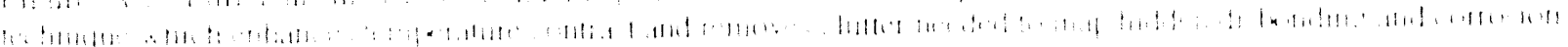



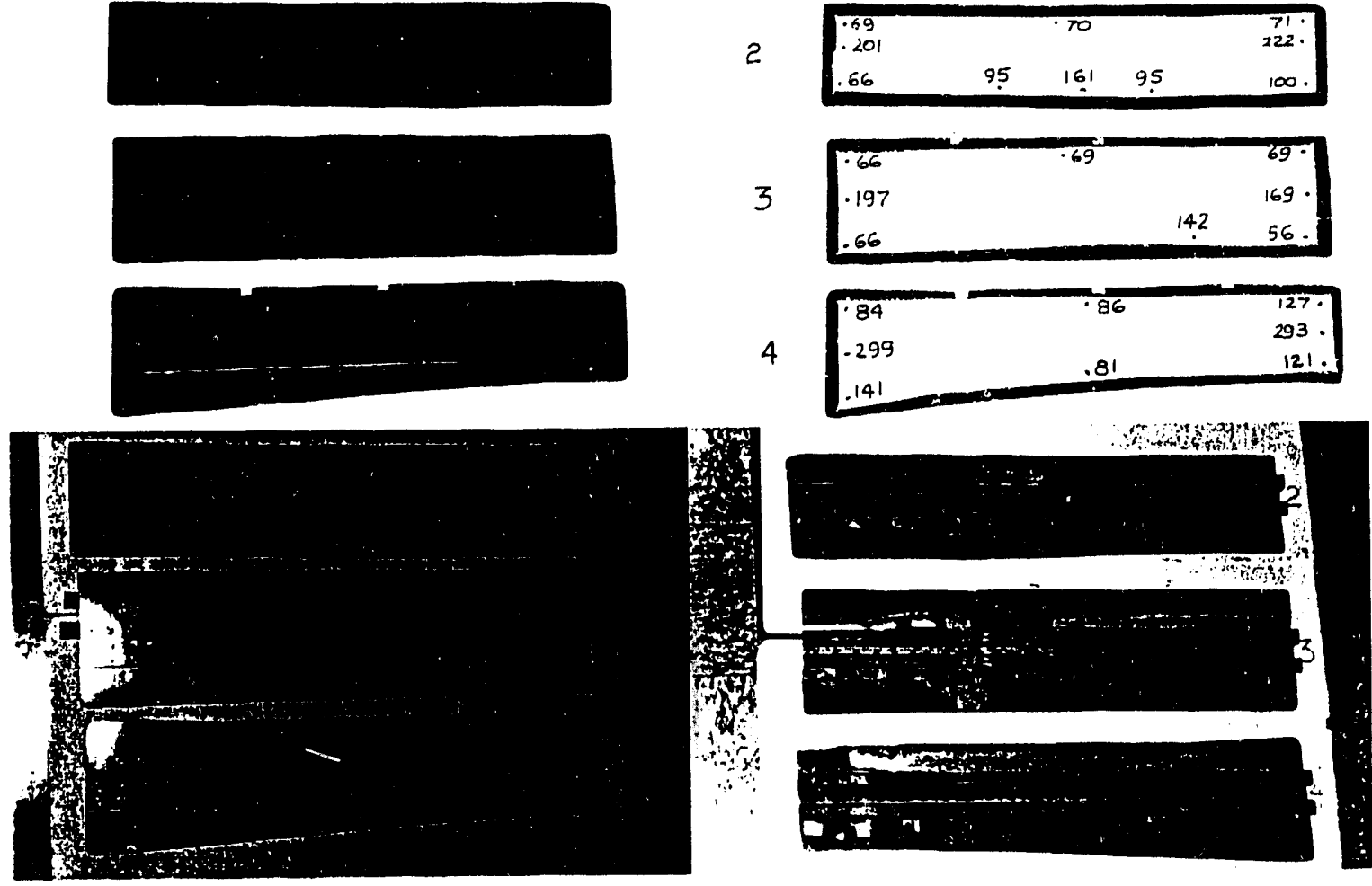

Figure A-3. Tinker AFB Panels 2, 3 and 4 (top to bottom) shown before black paint was removed (upper left), after black paint was removed (lower left), from the back side (lower right), and with thickness measurements in mils (thousandths of an inch, upper right). 

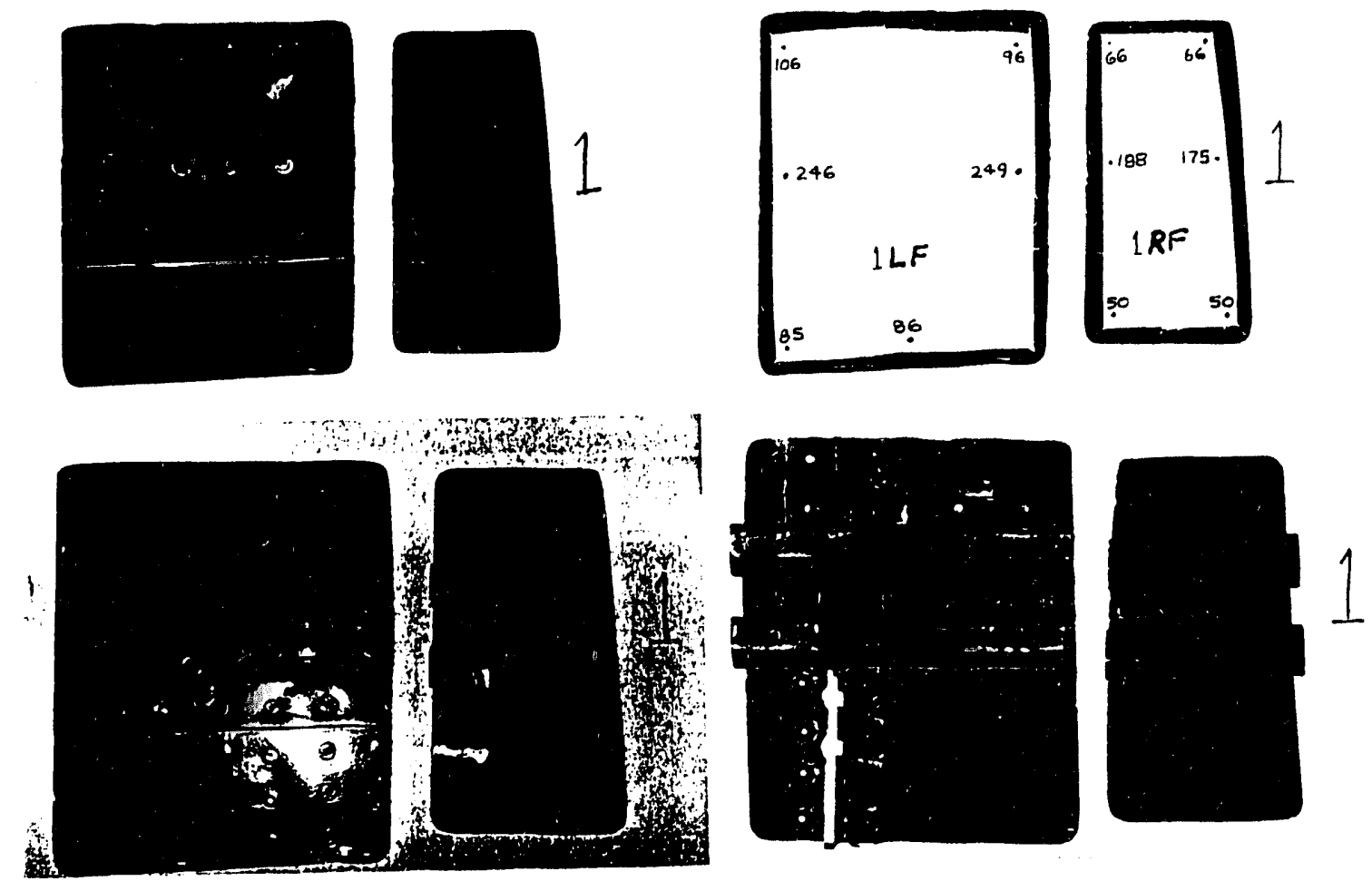

Figure A-4. Tinker AFB Panel 1 left (1LF) and right (1RF) end pieces shown before black paint was removed (upper left), after black paint was removed (lower left), from the back side (lower right), and with thickness measurements in mils (thousandths of an inch, upper right). 

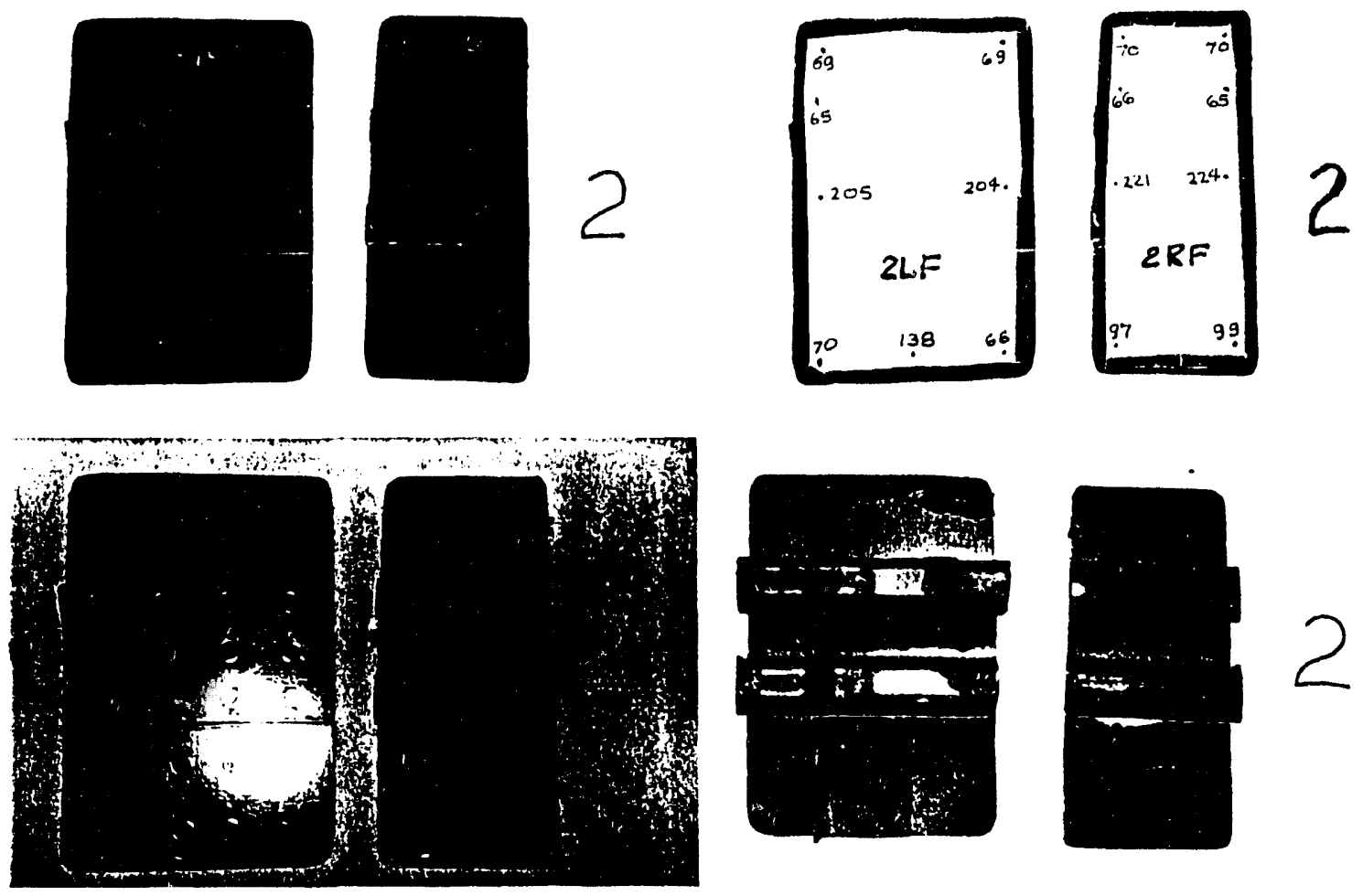

Figure A-5. Tinker AFB Panel 2 left (2LF) and right (2RF) end pieces shown before black paint was removed (upper left), after black paint was removed (lower left), from the back side (lower right), and with thickness measurements in mils (thousandths of an inch, upper right). 

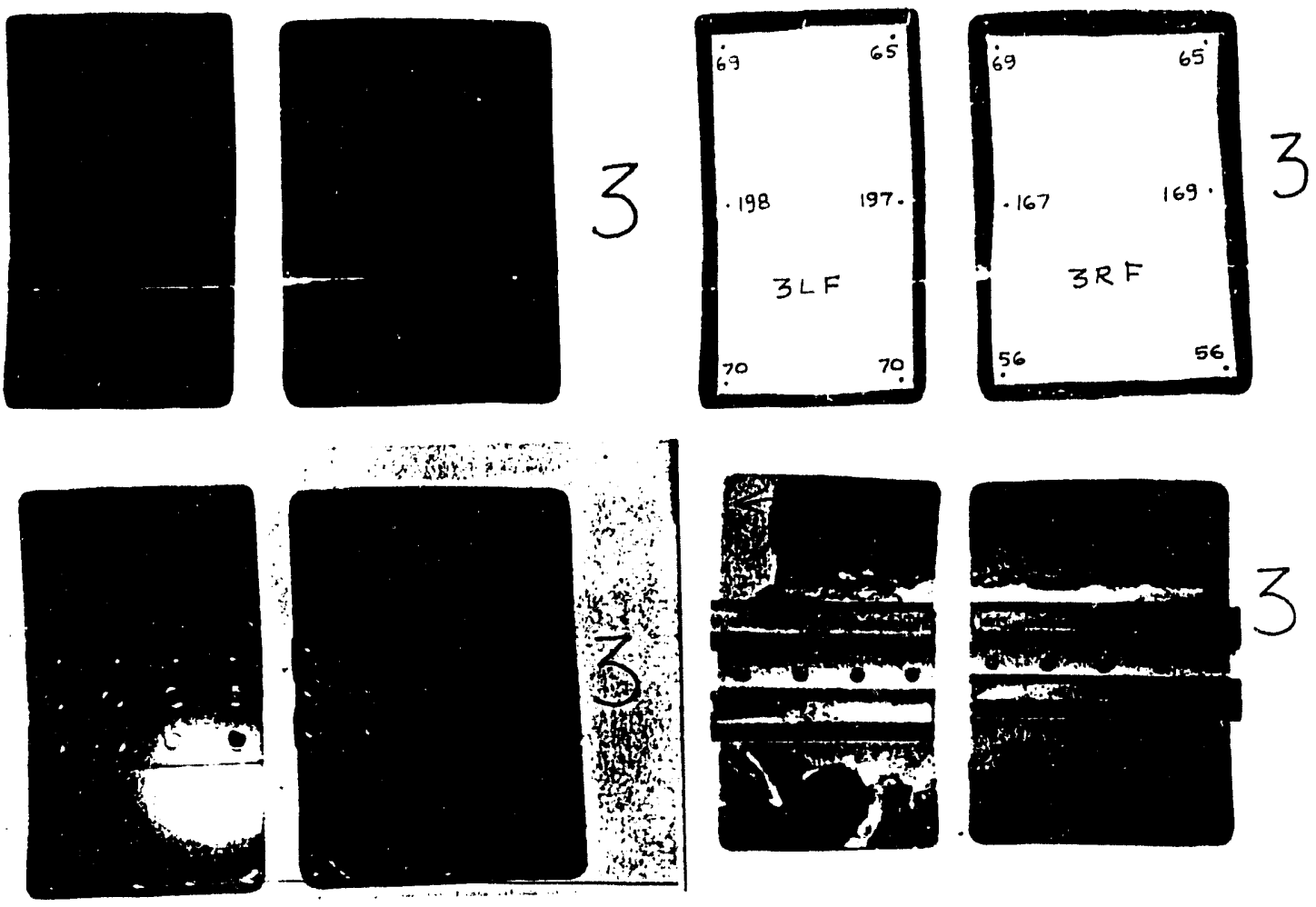

Figure A-6. Tinker AFB Panel 3 left (3LF) and right (3RF) end pieces shown before black paint was removed (upper left), after black paint was removed (lower left), from the back side (lower right), and with thickness measurements in mils (thousandths of an inch, upper right). 

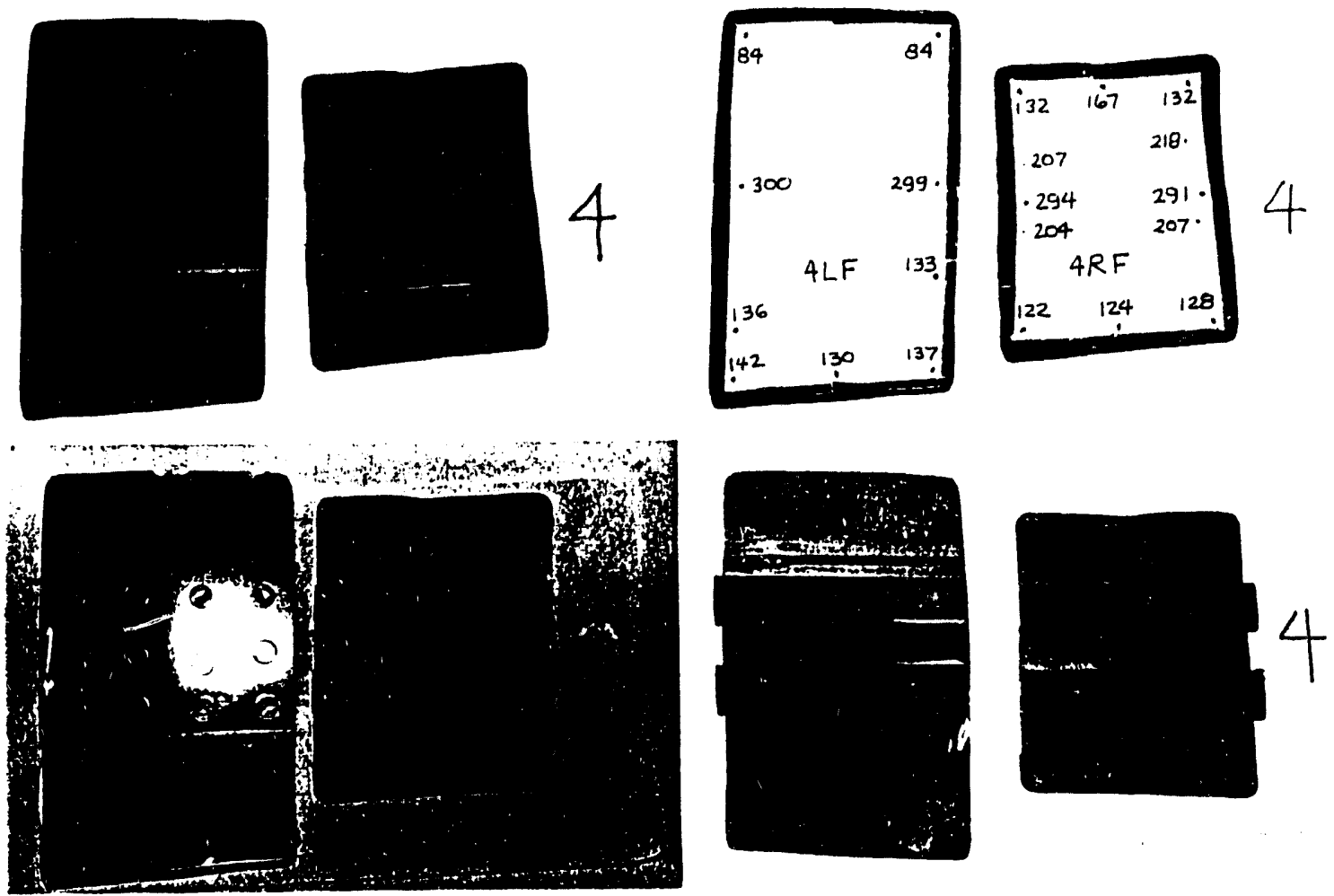

Figure A-7. Tinker AFB Panel 4 left (4LF) and right (4RF) end pieces shown before black paint was removed (upper left), after black paint was removed (lower left), from the back side (lower right), and with thickness measurements in mils (thousandths of an inch, upper right). 

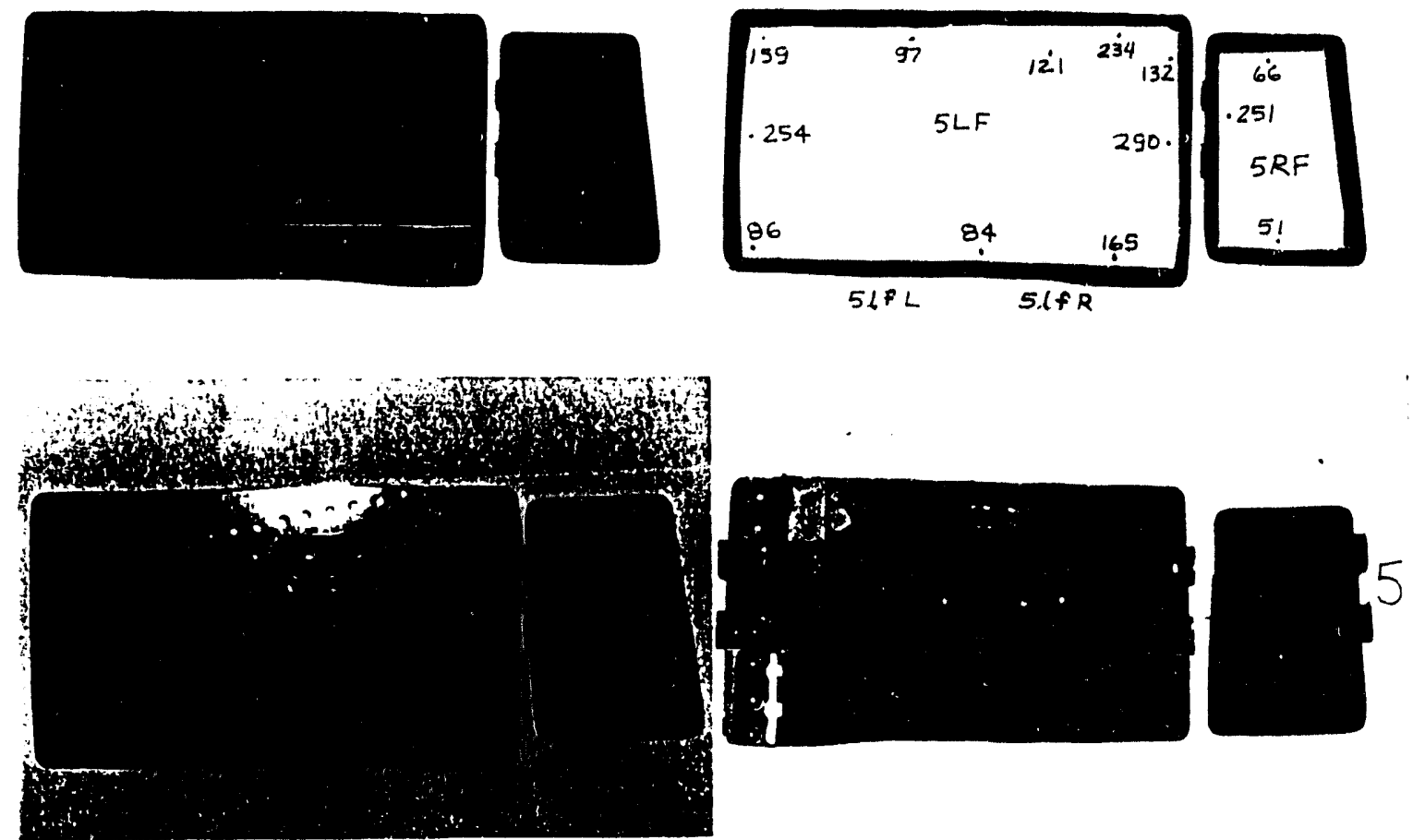

Figure A-8. Tinker AFB Panel 5 left (5LF) and right (5RF) end pieces shown before black paint was removed (upper left), after black paint was removed (lower left), from the back side (lower right), and with thickness measurements in mils (thousandths of an inch, upper right). 

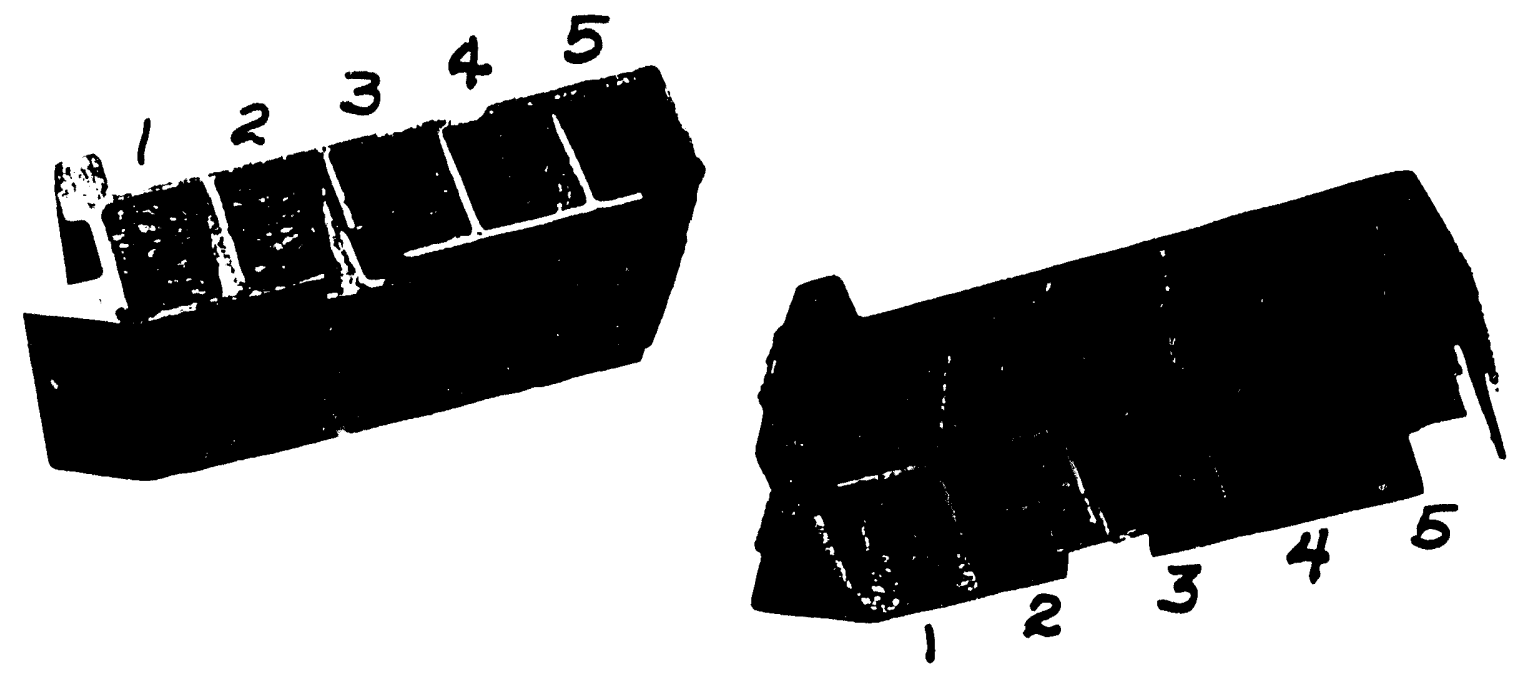

B 2
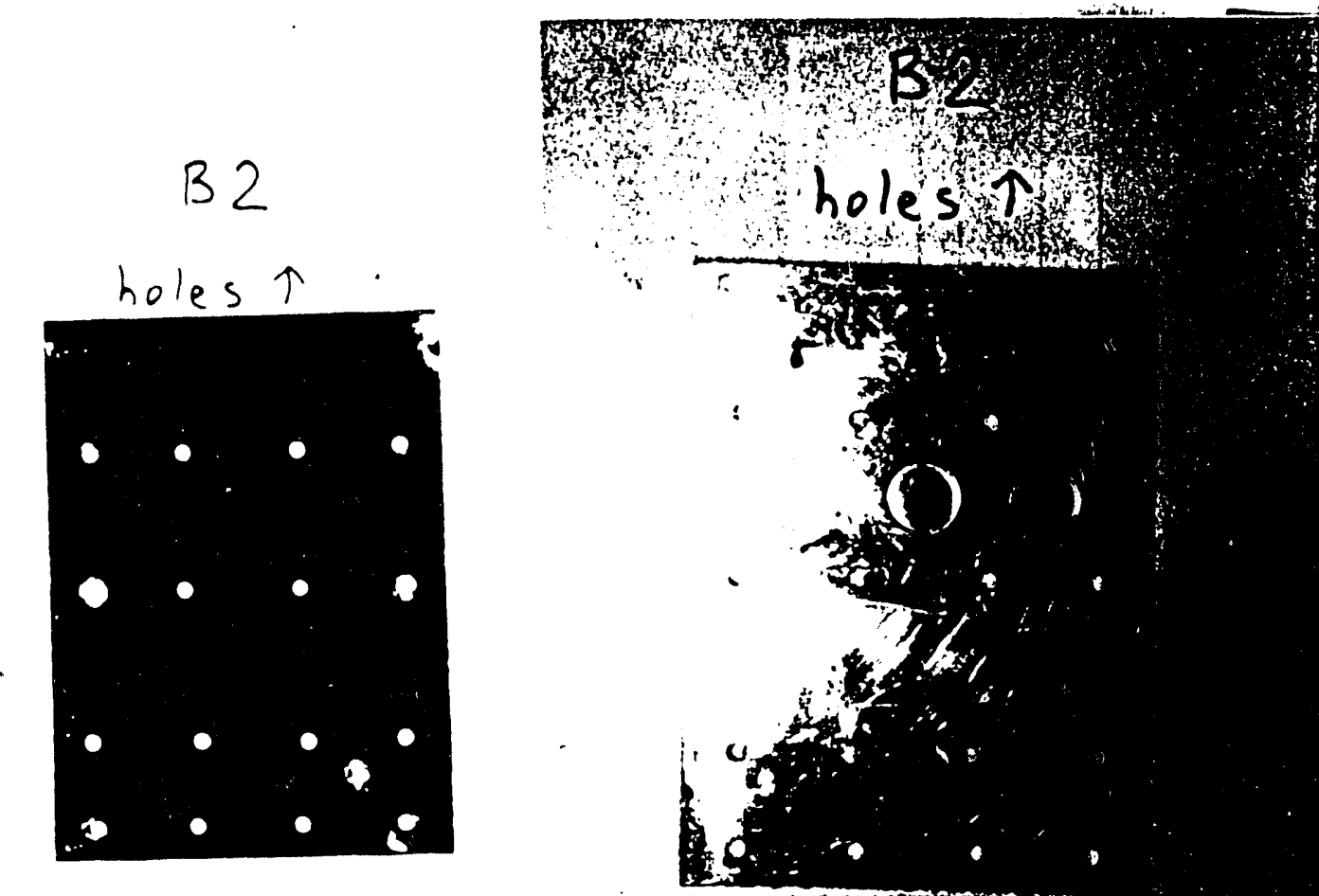

Figure A-9. Top left: front stele of F-18 wing hox structure which wals panted black to absorb four or five umes the heat absorbed by an unpannted aluminum surface. Note thickness differences left and right of vot between channel two and channel three. Top right: wing tox structure showing corrosion by-products at back face of front side. Bottom left and right: front and back side of $2.3 \mathrm{~mm}$ aluminum plate with $0.23 \mathrm{~mm}, 0.46 \mathrm{~mm}$ and $0.66 \mathrm{~mm}$ hat bollom holes thash heated from the front 


\section{APPENDIX B: COLOR-CODED IMAGES OF BOEING 737 AND TEST PANELS}

We show color-coded temperature patterns 0.4 seconds after flash-hcating the FAA/AANC Boeing 737 Aircraft fusclage lap splice structures and corrosion pancls: C115-122 from the AANC Library with a typical temperaturc rangc of $0.8^{\circ} \mathrm{C}$. Also. we show spot locations where temperature data were collected for use in Table 1. Tahle 2 and Table ?. Arcal hoxes were used in most instances to determine cool sites with minimal corrosion. 

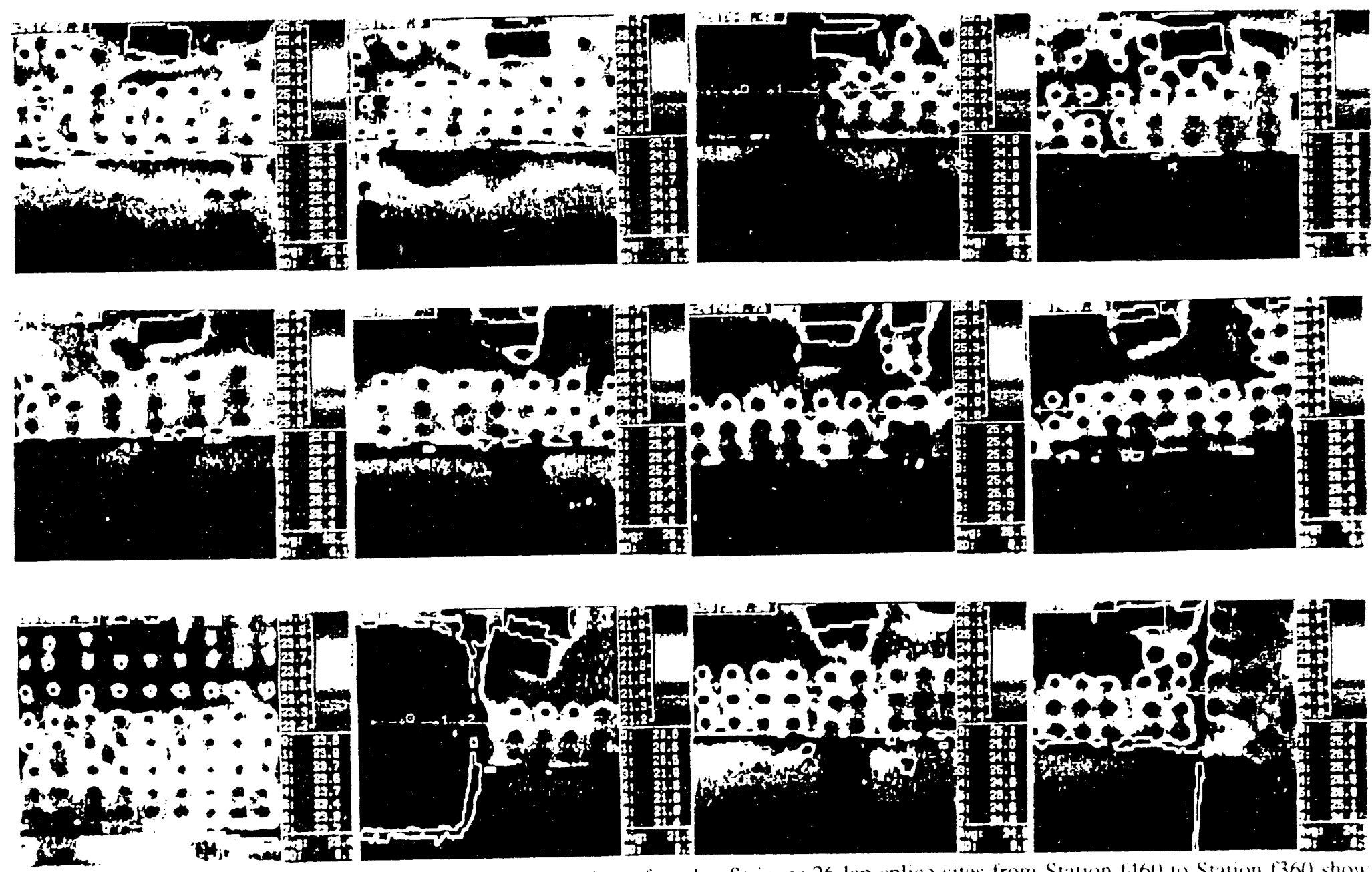

Figure B-1. Left to right, from top row to bottom row: an overview of twelve Stringer 26 lap splice siltes from Statton 1460 ) wo Station $136(1)$ show ing Agema 880 DBIR System long wavelenguh $(10 \mu \mathrm{m})$ color-coded lemperatures in ${ }^{\circ} \mathrm{C}$ at $0.4 \mathrm{~s}$ after the tlash. Note temperature profiles atong the lap splice where green, yellow and red represent increasing surface temperatures from skin thickness losses associated with corrosion. 

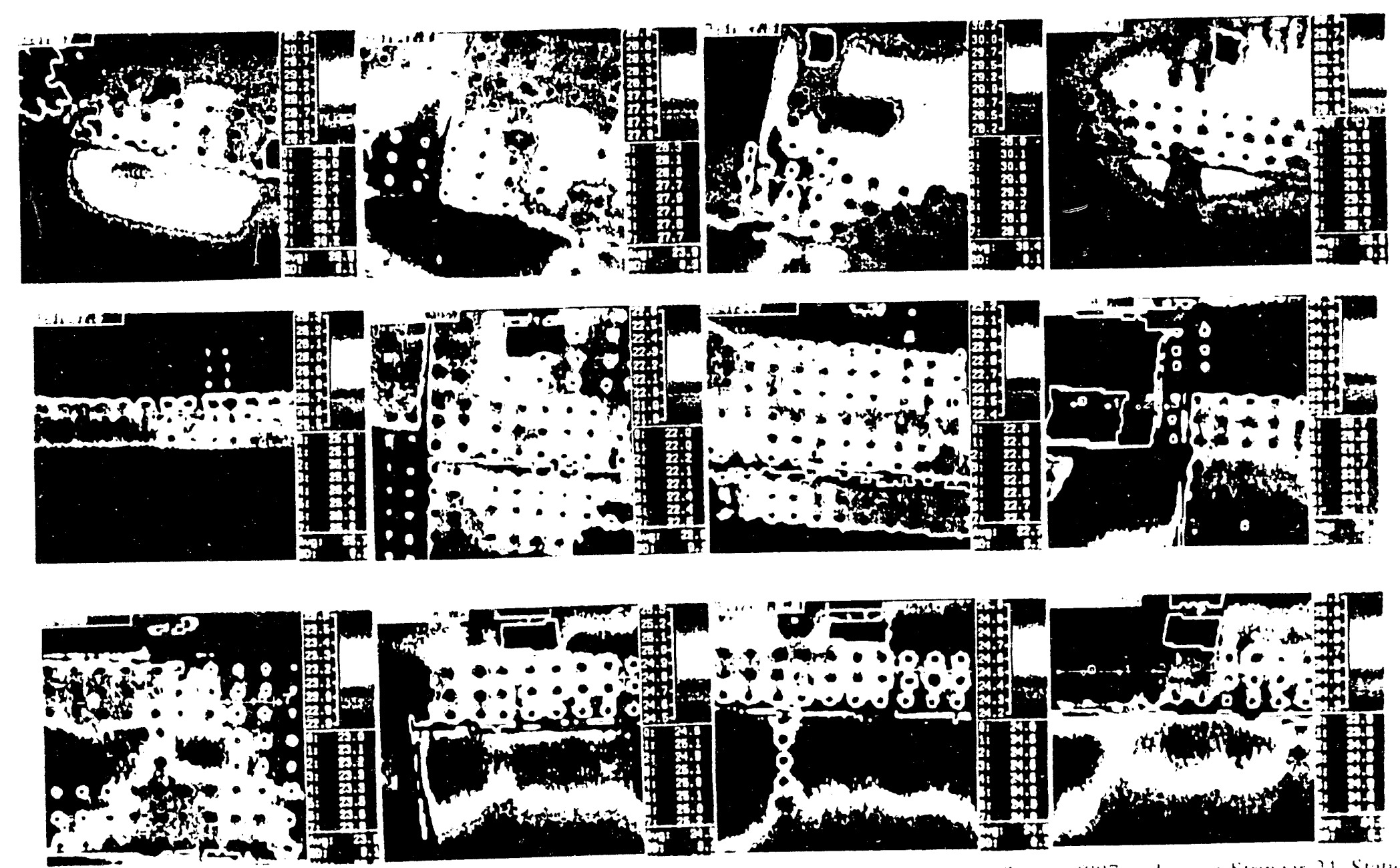

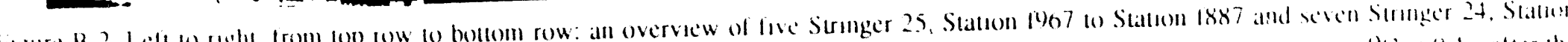
(i)

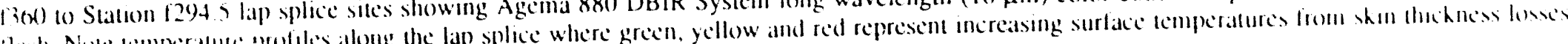
asseciated with corronist. 

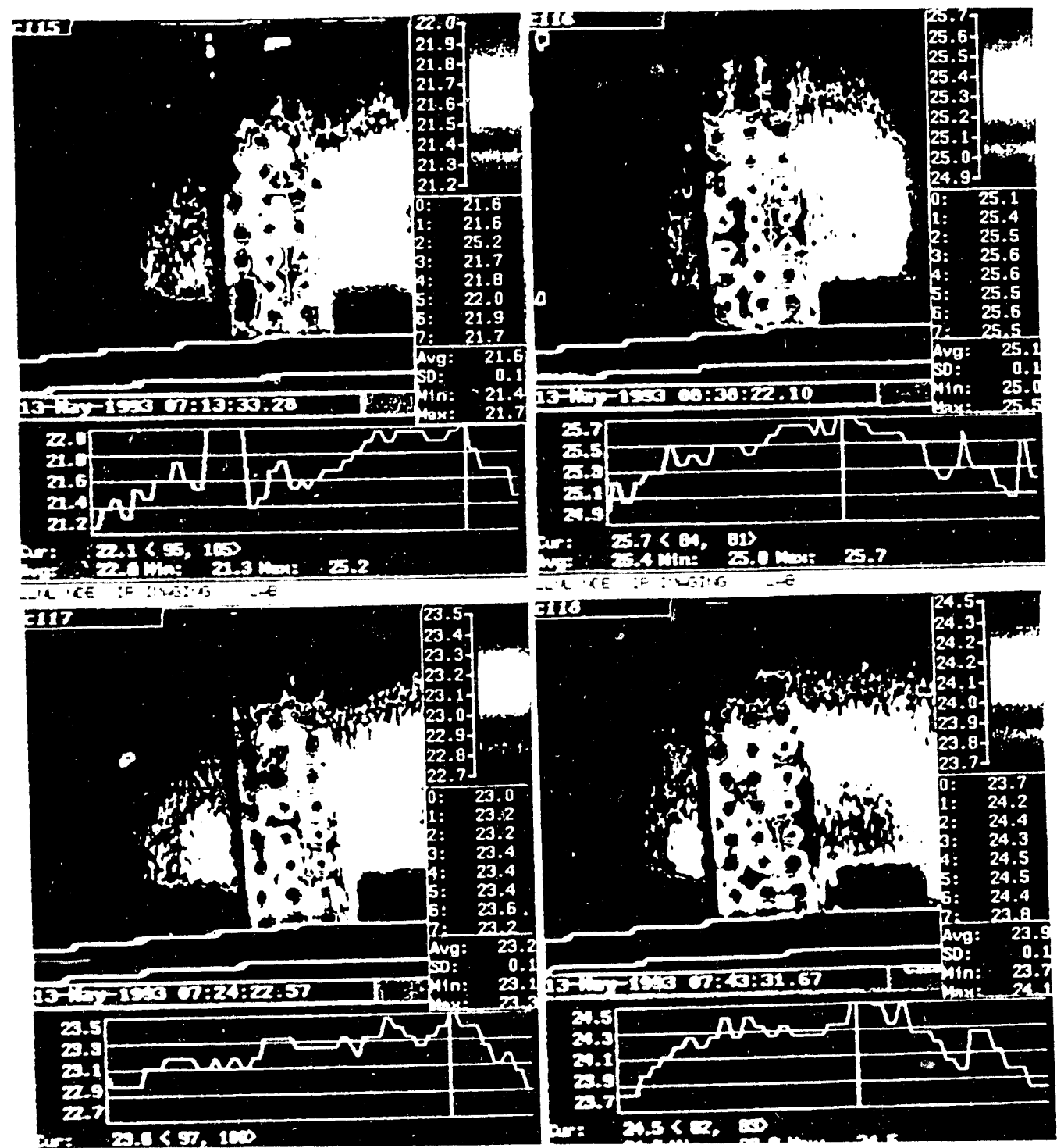

Figure B-3. Agema 880 DBIR System long wavelength $(10 \mu \mathrm{m})$ color-coded temperature patterns in ${ }^{\circ} \mathrm{C}$ at $0.4 \mathrm{~s}$ after the heat-flash. Top row, left to right, panels C115 and C116 were not exposed to solutions expected to cause corrosive action, while bottom row, left to right, panels $\mathrm{C} 117$ and $\mathrm{C} 118$ were exposed for 27 days to solutions expected to cause corrosive action (sce Table 1, Figure 14). 

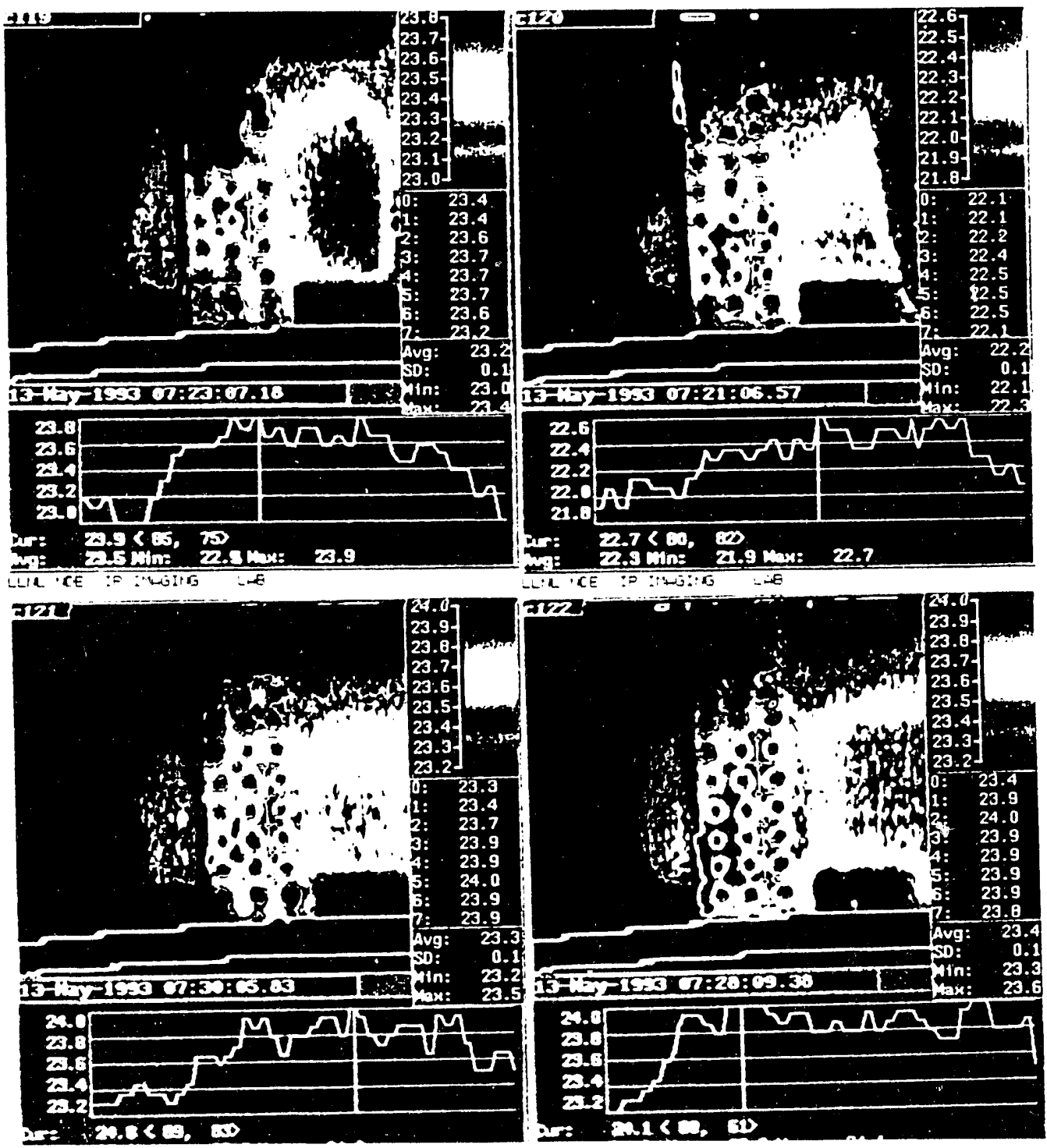

Figure B-4. Agerna 880 DBIR System long wavelength $(10 \mu \mathrm{m})$ color-coded temperature patterns in ${ }^{\circ} \mathrm{C}$ at $0.4 \mathrm{~s}$ after the heat-nlash. Top row, left to right, panels C119 and C120) were exposed for 42 days to solutions expected to cause corrosive action, while bottom row, left to right, panels $\mathrm{C} 121$ and $\mathrm{C} 122$ were exposed for 54 days to solutions expected to cause corrosive action (see Table 1. Figure 15). 

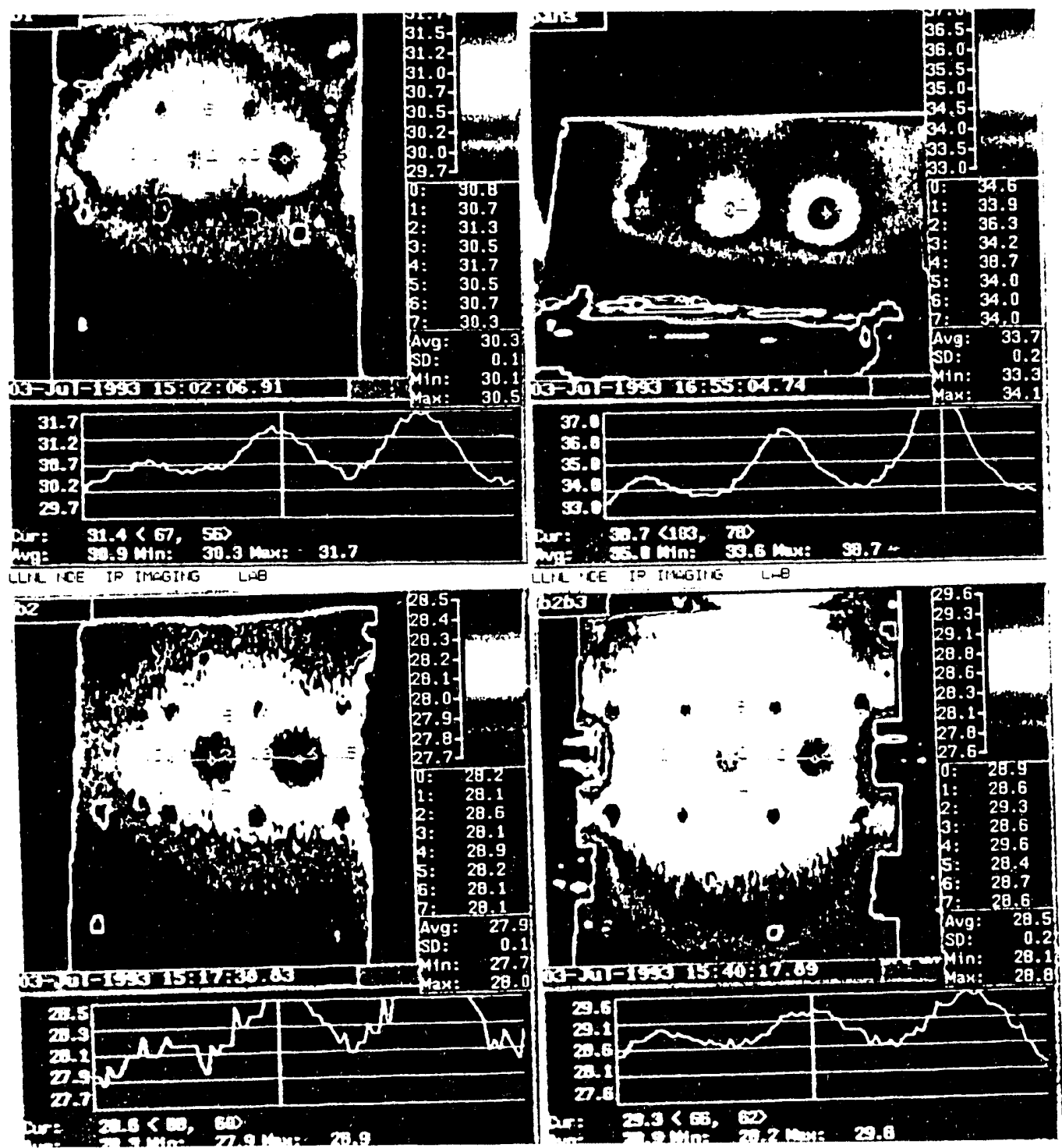

Figure B-5. Agema 880 DBIR System long wavelength $(10 \mu \mathrm{m})$ color-coded temperature patterns in ${ }^{\circ} \mathrm{C}$ at $0.4 \mathrm{~s}$ after the heat-flash. Top row, left to right, show panel Bl $(1.1 \mathrm{~mm}$, with $9 \%, 19 \%$ and $28 \%$ thickness-loss holes) and panel S (1.0 $\mathrm{mm}$, with $20 \%, 40 \%$ and $62 \%$ thickness-loss holes), while bottom row, left to right, show panel B2 $(2.3 \mathrm{~mm}$, with $10 \%$, $19 \%$ and $28 \%$ and composite panel B2B3 $(3.9 \mathrm{~mm}$, with $6 \%, 12 \%$ and $17 \%$ thickness-loss holes). See Table 1, Figure 16. 

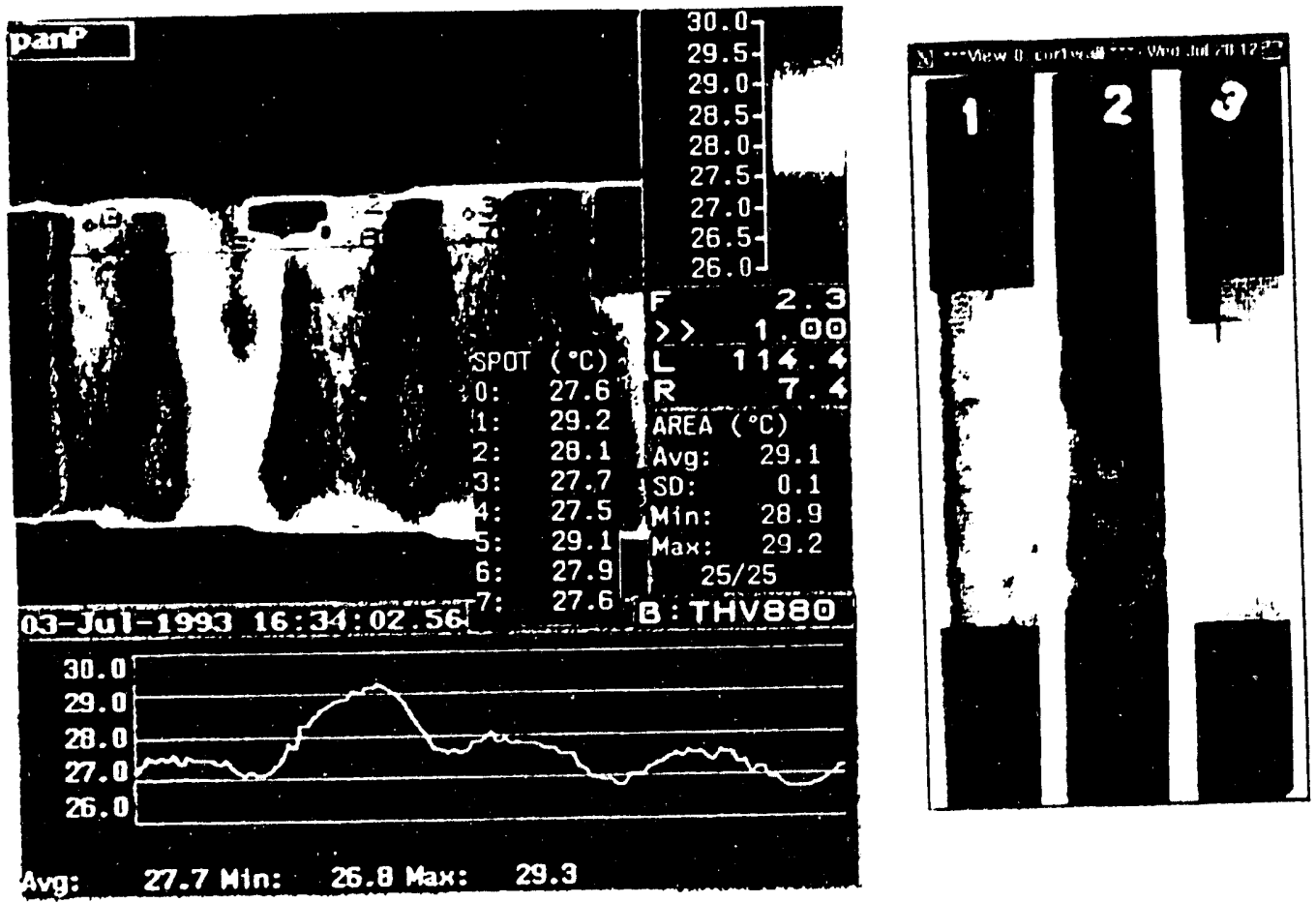

Figure B-6. Left: Agema 880 DBIR System long wavelength $(10 \mu \mathrm{m})$ color-coded temperature patterns in ${ }^{\circ} \mathrm{C}$ at $0.4 \mathrm{~s}$ after the heat-flash for F-18 wing box structure spot temperatures $0-7$ and area box temperature (near spot 5) corresponded to sites where channel thickness measurements were made. The thickness loss per degree Celsius for the 2.9 mm (uncorroded thickness) structure was $22.1 \%$ (or $0.643 \mathrm{~mm}$ ). Right: $x$-ray radiograph of corroded wing box structure showing three channels from left side of the flash-heated front face, which was painted black. 


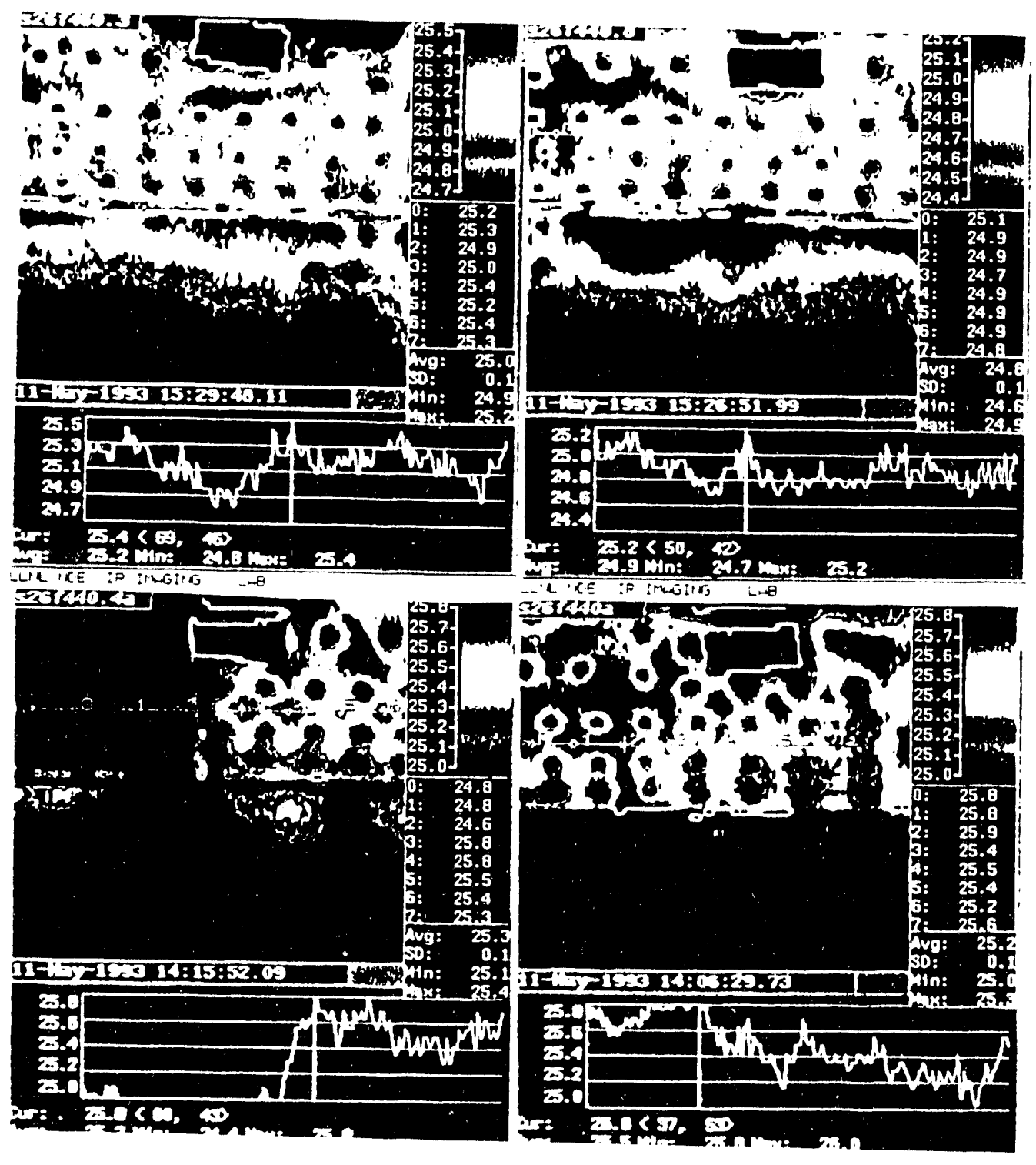

Figure B-7. Bocing 737, Stringer 26 Agerna 880 DBIR System long wavelength $(10 \mu \mathrm{m})$ color-coded temperatures in ${ }^{\circ} \mathrm{C}$ at Station f $440.8(80 \%$ as shown in four images from top row, left to right, Station 646() $.3(30 \%$ aft, toward next station) and Station f44(). See Table 2, Figure 17 . 

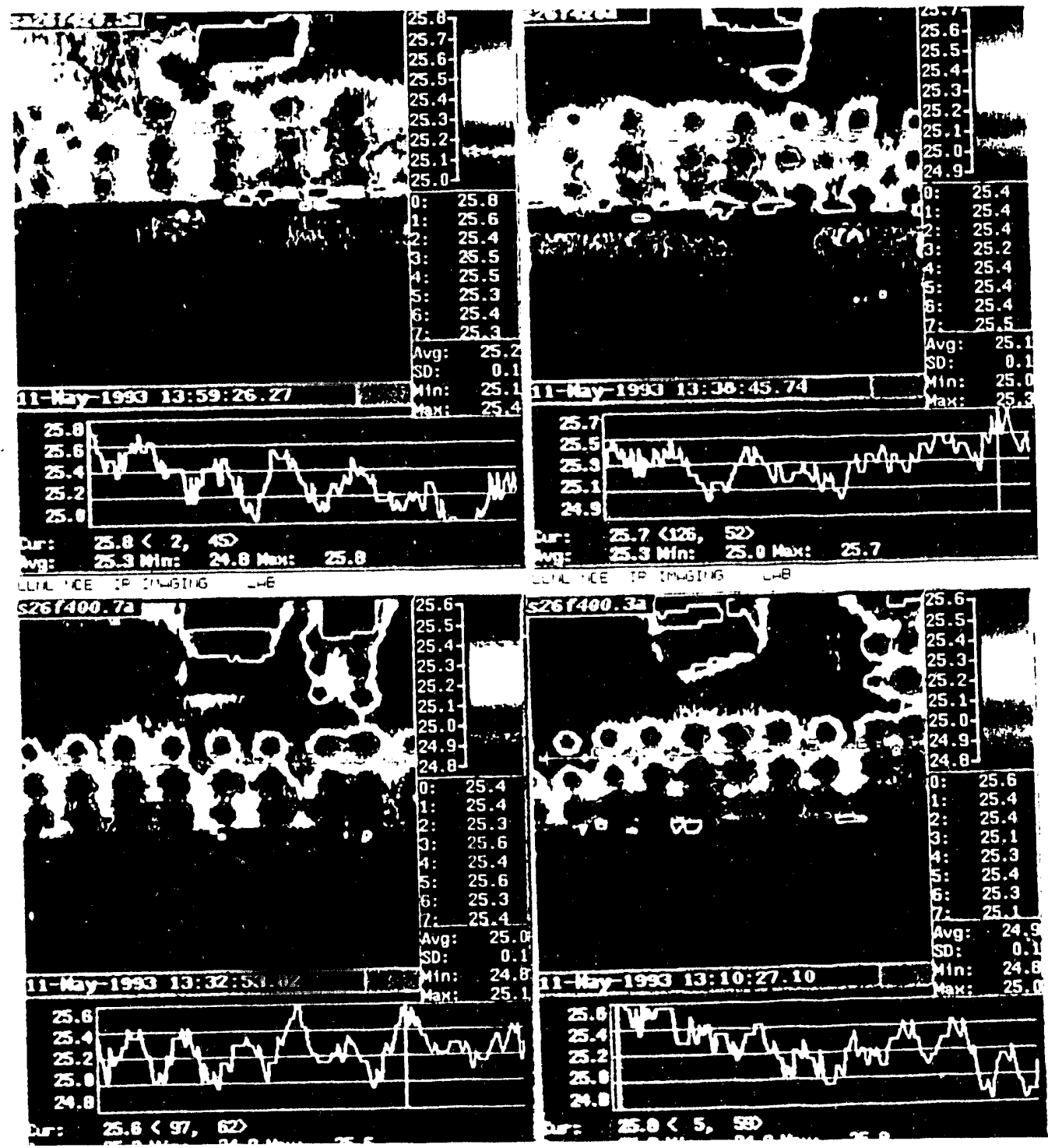

Figure B-8. Boeing 737. Stringer 26 Agema 880 DBIR System long wavelength (10 $\mu \mathrm{m})$ color-coded temperatures in ${ }^{\circ} \mathrm{C}$ at $0.4 \mathrm{~s}$ after flash, as shown in four images from top row, left to right, Station $\mathrm{f} 420.5$ ( $50 \%$ aft, toward next station) and Station $\mathrm{f4} 20$ and bottom row, left to right, Station $\mathrm{f} 400.7(70 \%$ aft, toward next station) and Station $\mathrm{f} 400.3$ (30\% aft, toward next station). See Table 2, Figure 18. 


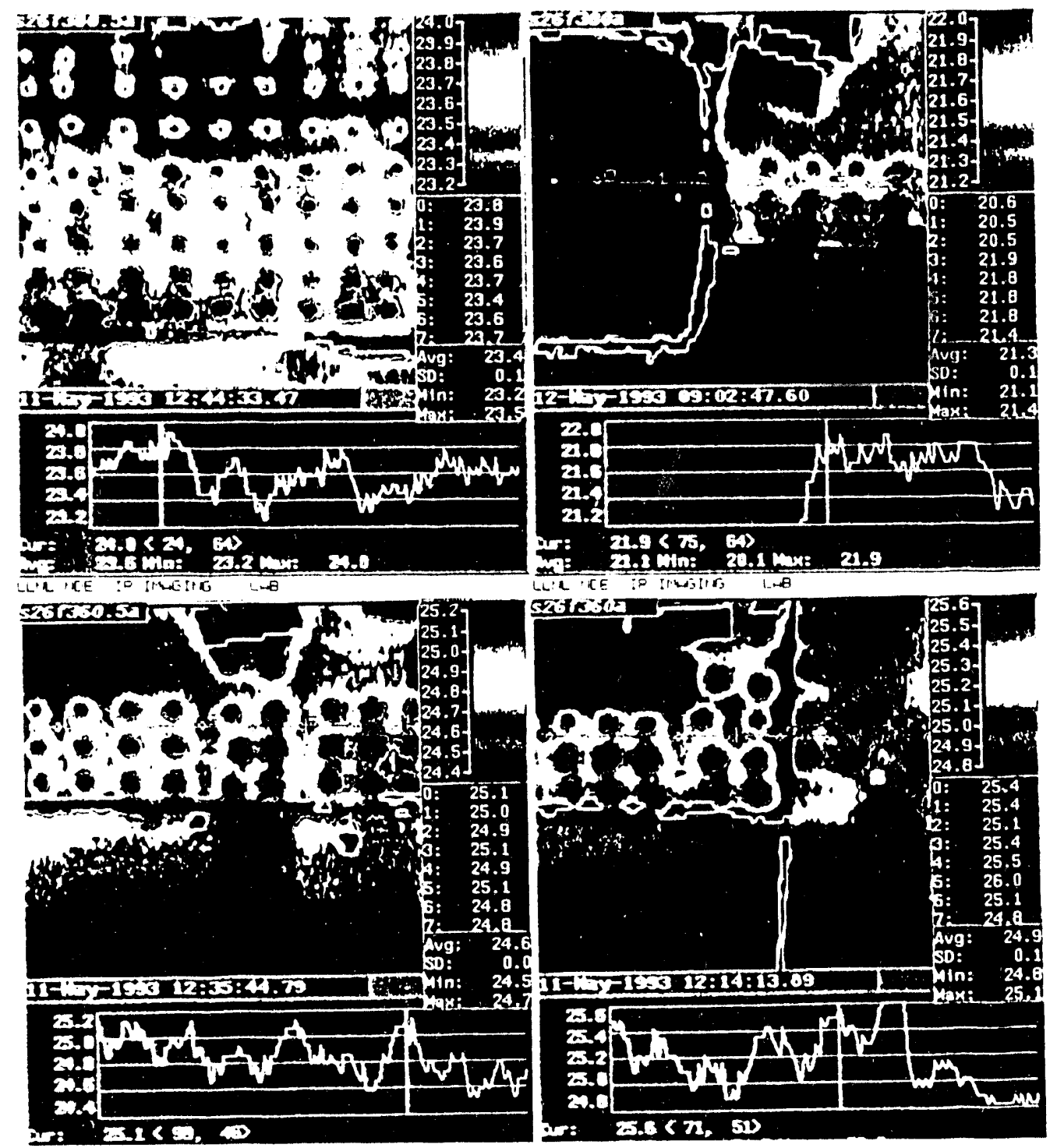

Figure B-9. Boeing 737, Stringer 26 Agema 880 DBIR System long wavelength $(10 \mu \mathrm{m})$ color-code 1 temperatures in ${ }^{\circ} \mathrm{C}$ at $0.4 \mathrm{~s}$ after flash, as shown in four images from top row, left to right, Station $1380.5(50 \%$ aft, loward next station) and Station 380 and bottom row, left to right, Station 1360.5 (50\% aft, toward next station) and Station B60. See Table 2, Figure 19. 

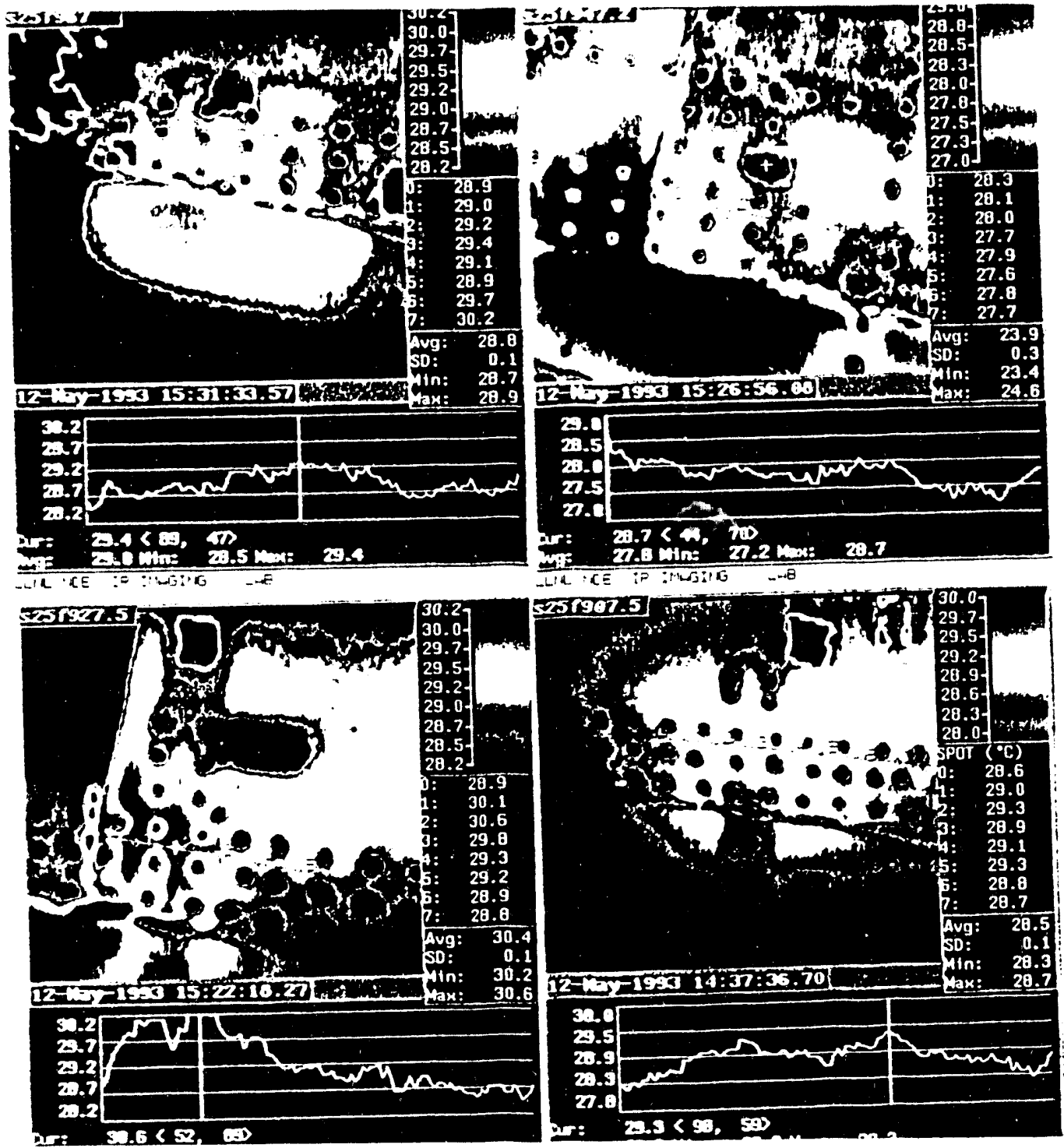

Figure B-10. Boeing 737, Stringer 25 Agema 880 DBIR Systern long wavelength $(10 \mu \mathrm{m})$ color-coded temperatures in ${ }^{\circ} \mathrm{C}$ at $0.4 \mathrm{~s}$ after flash, as shown in four images from top row, left to right, Station $\mathrm{f} 967$ and Station $1947.2(20 \%$ aft, toward next station) and bottom row, left to right, Station 927.5 (50\% aft, toward next station) and Station 9907.5 (50\% aft, toward next station). See Table 3, Figure 20. 


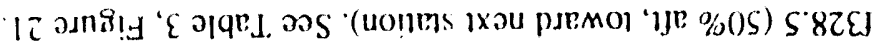
uonens pue (uones ixou puemol '

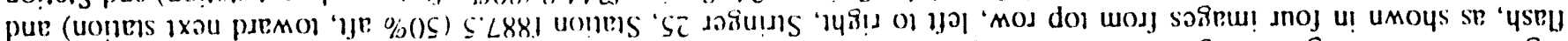

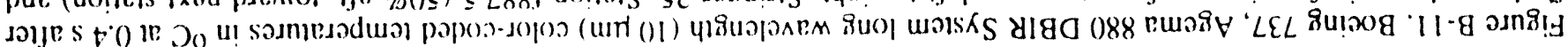

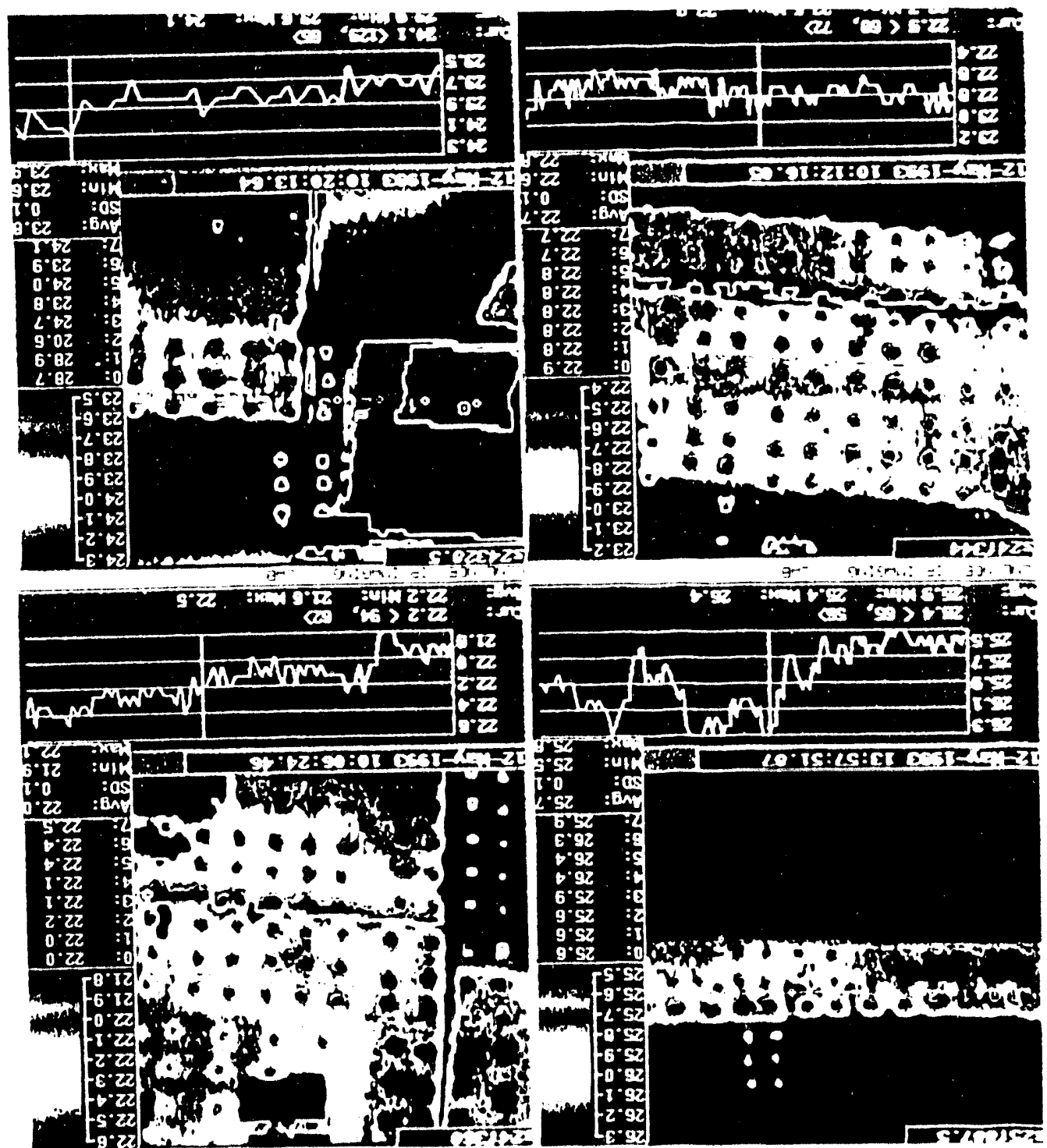




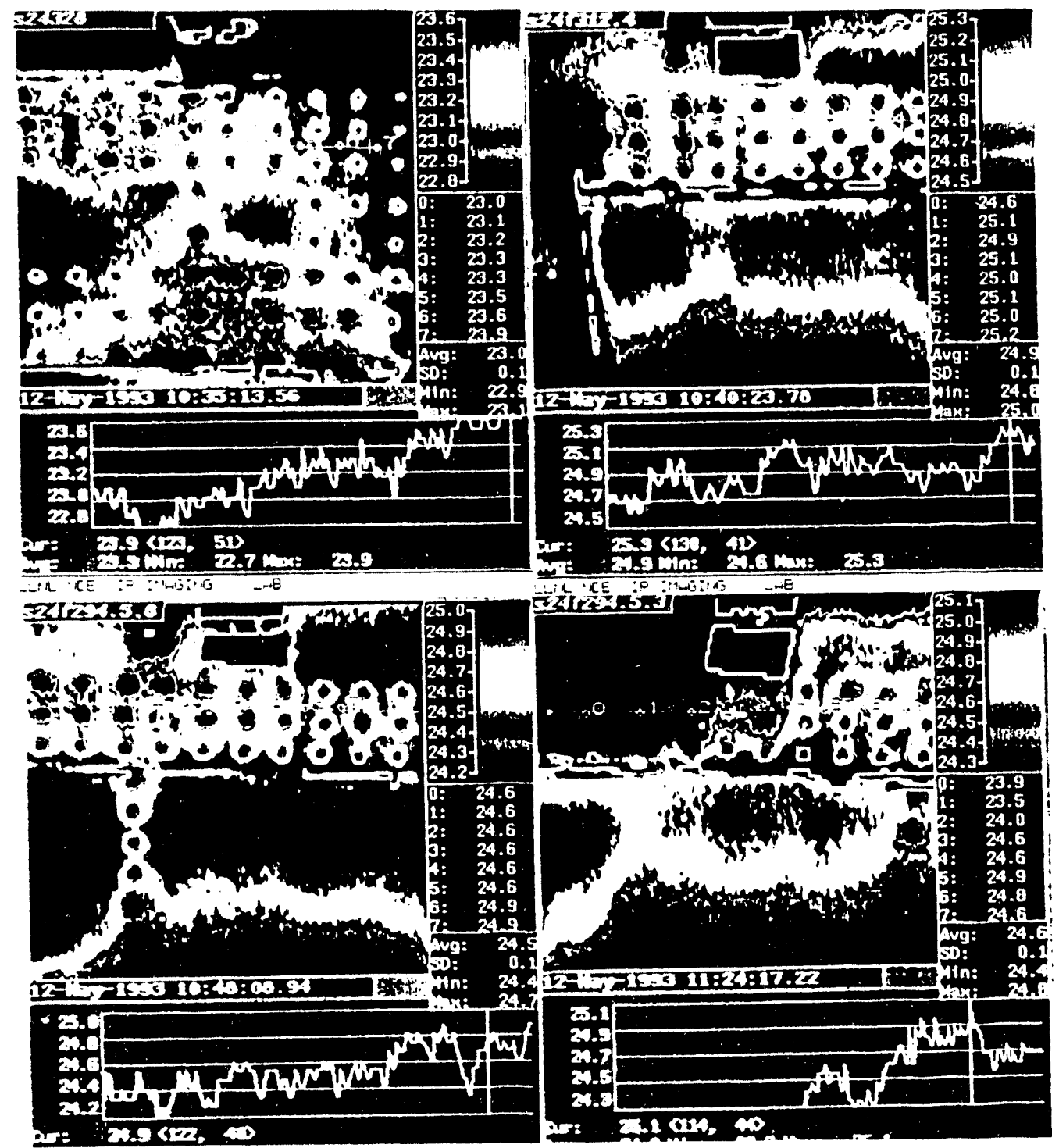

Figure B-12. Boeing 737, Stringer 24 Agema 880 DBIR System long wavelength (10 $\mu \mathrm{m})$ color-coded temperatures in ${ }^{\circ} \mathrm{C}$ at $0.4 \mathrm{~s}$ after flash, as shown in four images from top row, left to right, Station 328 and Station $312.4(40 \%$ aft, toward next station) and bottom row, left to right, Station $294.5 .8(80 \%$ aft of Station 294.5$)$ anit Station $294.5 .3(30 \%$ aft of Station 294.5). See Table 3, Figure 22. 


\section{APPENDIX C: COLOR-CODED IMAGES OF BOEING KC-135 PANELS}

We show color-coded temperature patterns 0.4 seconds after flash-heating the Tinker AFB Boeing KC-13.5 Inspection Pancls $2-4$ using a temperature range of $4^{\circ} \mathrm{C}$, and end pieces for Pancls 1.5 using a lemperature range of $2^{\circ} \mathrm{C}$. Also, we show spoll locations where temperature data were collected for use in Table 4 and Table 5. Area boxes were used in most inslances to determine cool sites with minimal corrosion. 


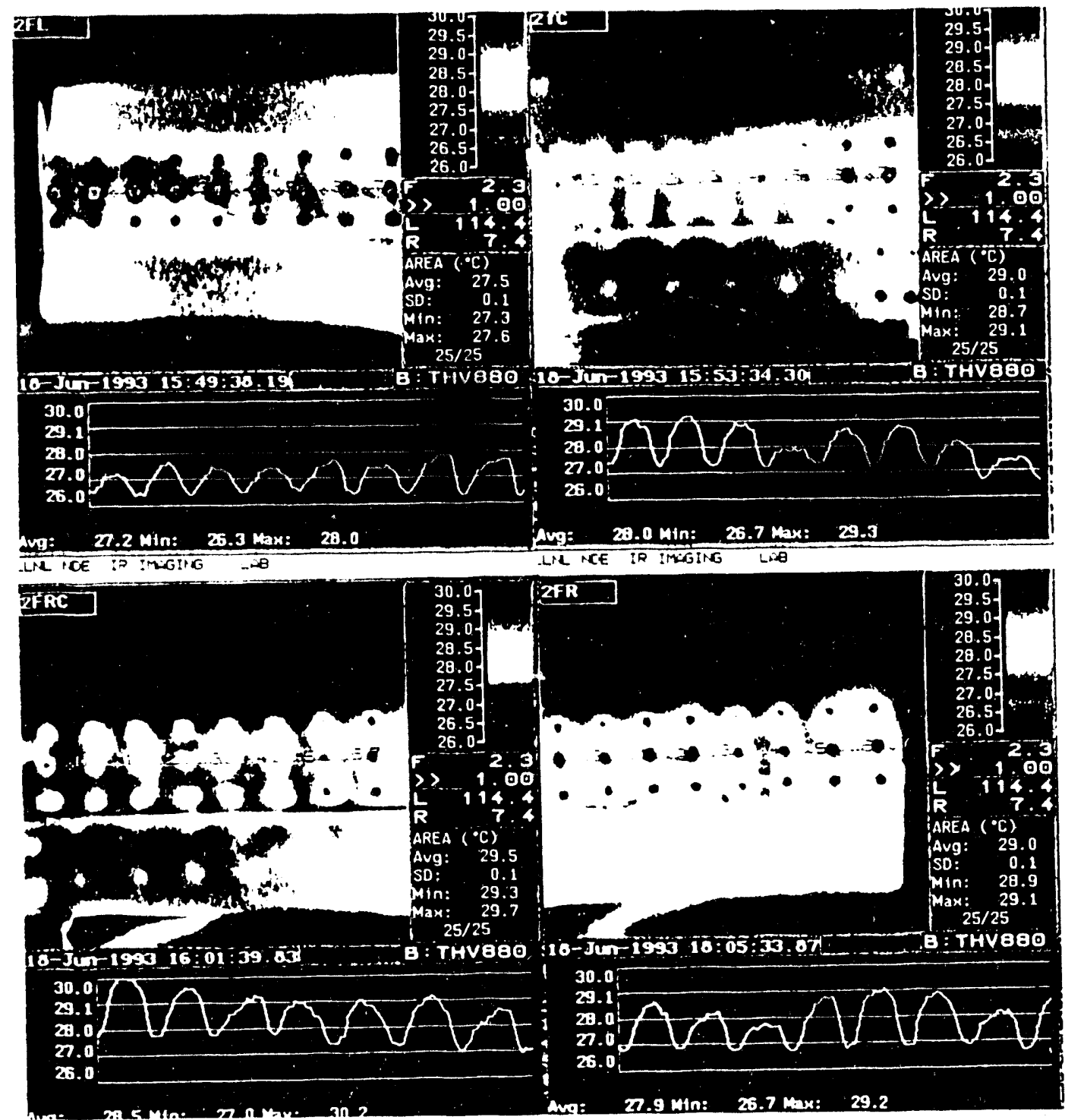

Figure C-1. Panel 2 Agema 880 DBIR System long wavelength $(10 \mu \mathrm{m})$ color-coded temperatures in ${ }^{\circ} \mathrm{C}$ at $0.4 \mathrm{~s}$ after flash, as shown in four images from top row, left to right (left edge to center) and bottom row, left to right (center to right edge). Note temperature profile across line through center of lap splice with average temperature for area box near spot 4. Temperature data at spots 0 through 7 are included in Table 4. 


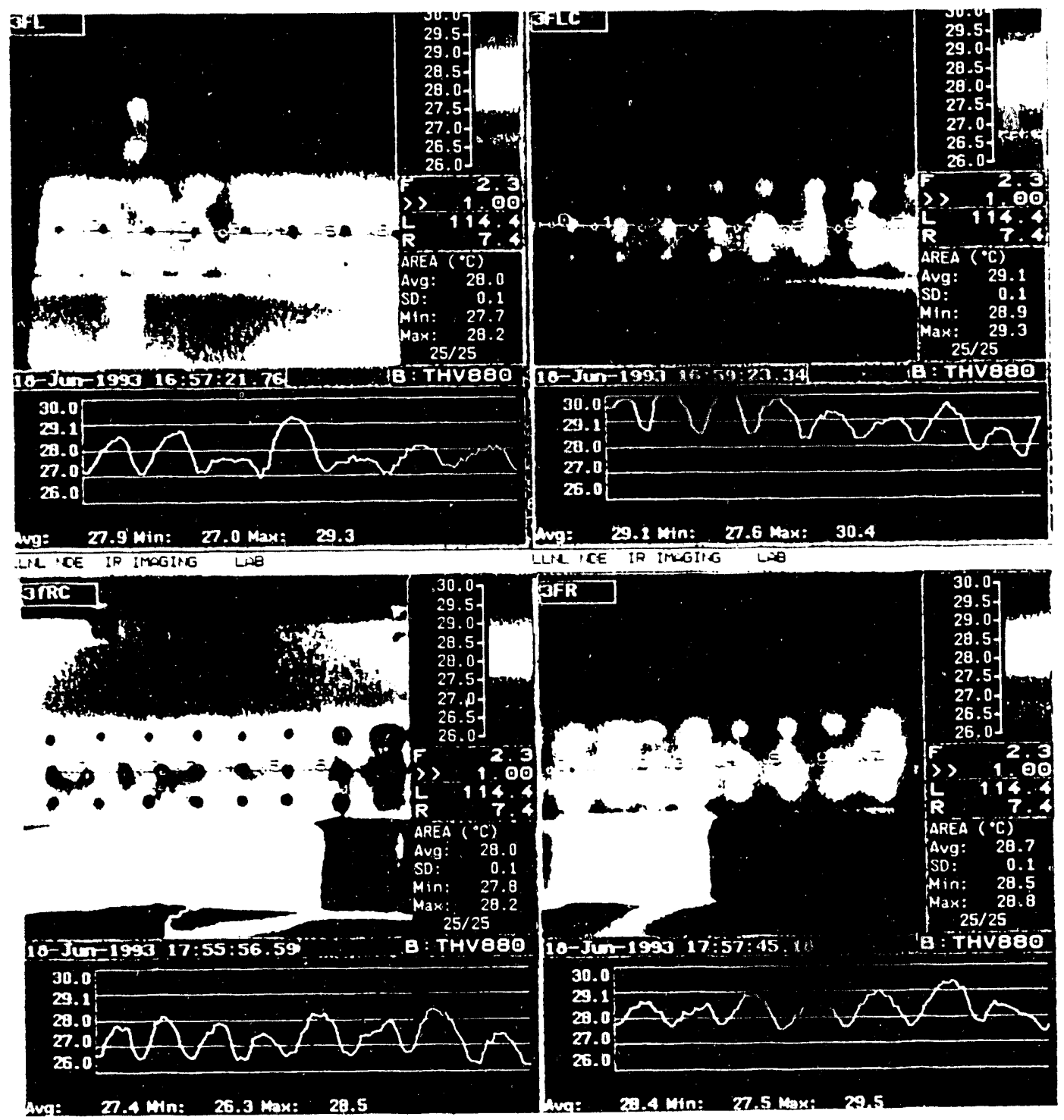

Figure C-2. Panel 3 Agema 880 DBIR System long wavelength $(10 \mu \mathrm{m})$ color-coded temperatures in ${ }^{\circ} \mathrm{C}$ at $0.4 \mathrm{~s}$ after flash, as shown in four images from top row, left to right (left edge to center) and bottom row, left to right (center to right edge). Note temperature profile across line through center of lap splice with average temperature for area box near spot 4. Temperature dats at spots 0 through 7 are included in Table 4 . 


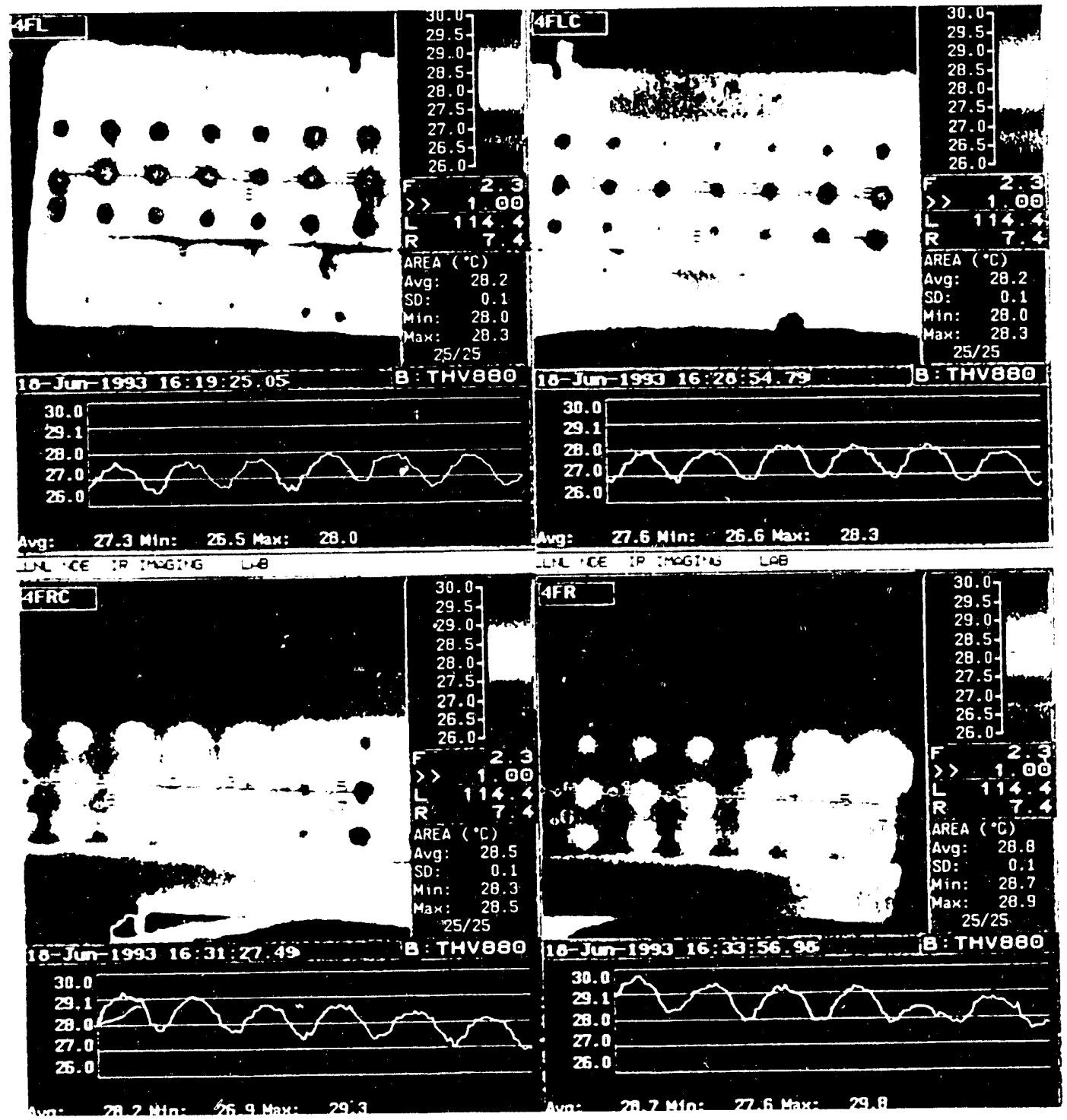

Figure C-3. Panel 4 Agema 880 DBIR System long wavelength $(10 \mu \mathrm{m})$ color-coded temperatures in ${ }^{\circ} \mathrm{C}$ at $0.4 \mathrm{~s}$ after flash, as shown in four images from top row, left to right (left edge to center) and bottom row, left to right (center to right edge). Note temperature profile across line through center of lap splice with average temperature for area box near spot 4. Temperature data at spots 0 through 7 are included in Table 4 . 


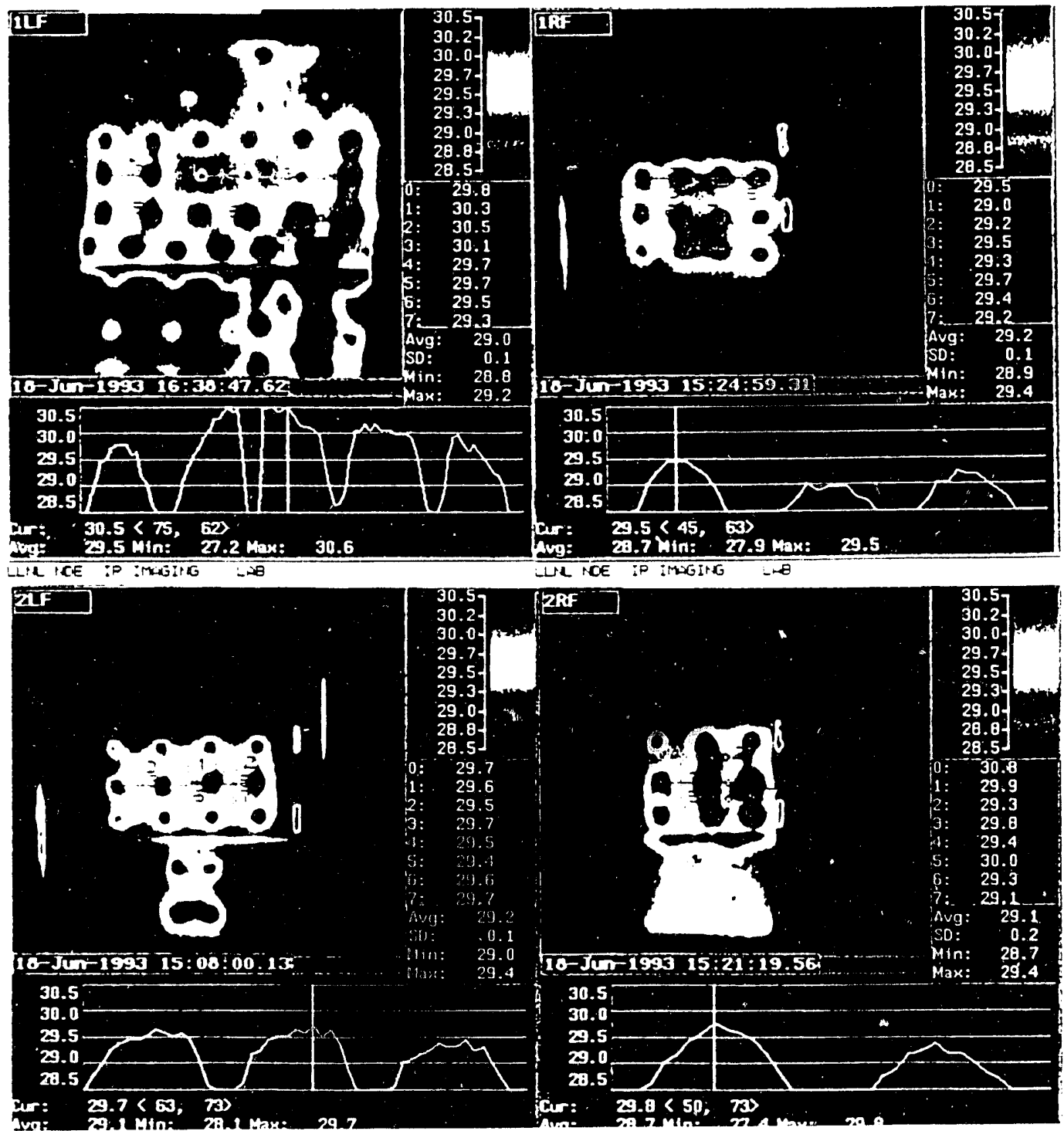

Figure C-4. Top row, left to right: Panel 1 left and right end piece images of Agema 880 DBIR System long wavelength (10 $\mu \mathrm{m})$ color-coded temperatures in ${ }^{\circ} \mathrm{C}$ at $0.4 \mathrm{~s}$ after flash. Bottom row left to right: Panel 2 left and right end piece images of Agema 880 DBIR System long wavelength $(10 \mu \mathrm{m})$ color-coded temperatures in ${ }^{\circ} \mathrm{C}$ at $0.4 \mathrm{~s}$ after flash. Temperature data at spots 0 through 7 are included in Table 5 . 


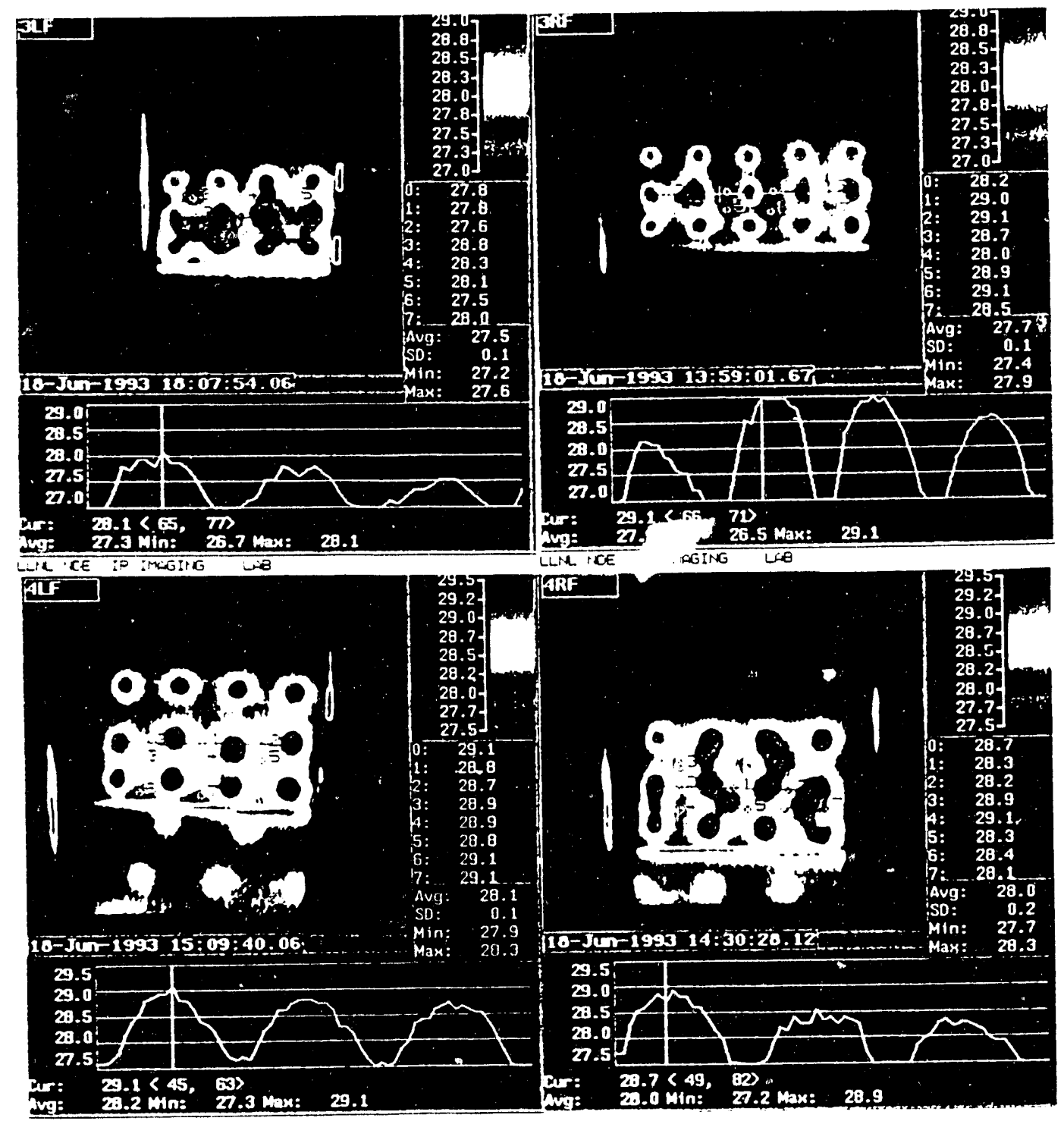

Figure C-5. Top row, left to right: Panel 3 left and right end piece images of Agema 880 DBIR System long wavelength (10 $\mu \mathrm{m})$ color-coded temperatures in ${ }^{\circ} \mathrm{C}$ at $0.4 \mathrm{~s}$ after flash. Bottom row, left to right: Panel 4 left and right end piece images of Agema $880 \mathrm{DBIR}$ System long wavelength $(10 \mu \mathrm{m})$ color-coded temperatures in ${ }^{\circ} \mathrm{C}$ at $0.4 \mathrm{~s}$ after flash. Temperature data at spots 0 through 7 are included in Table 5. 


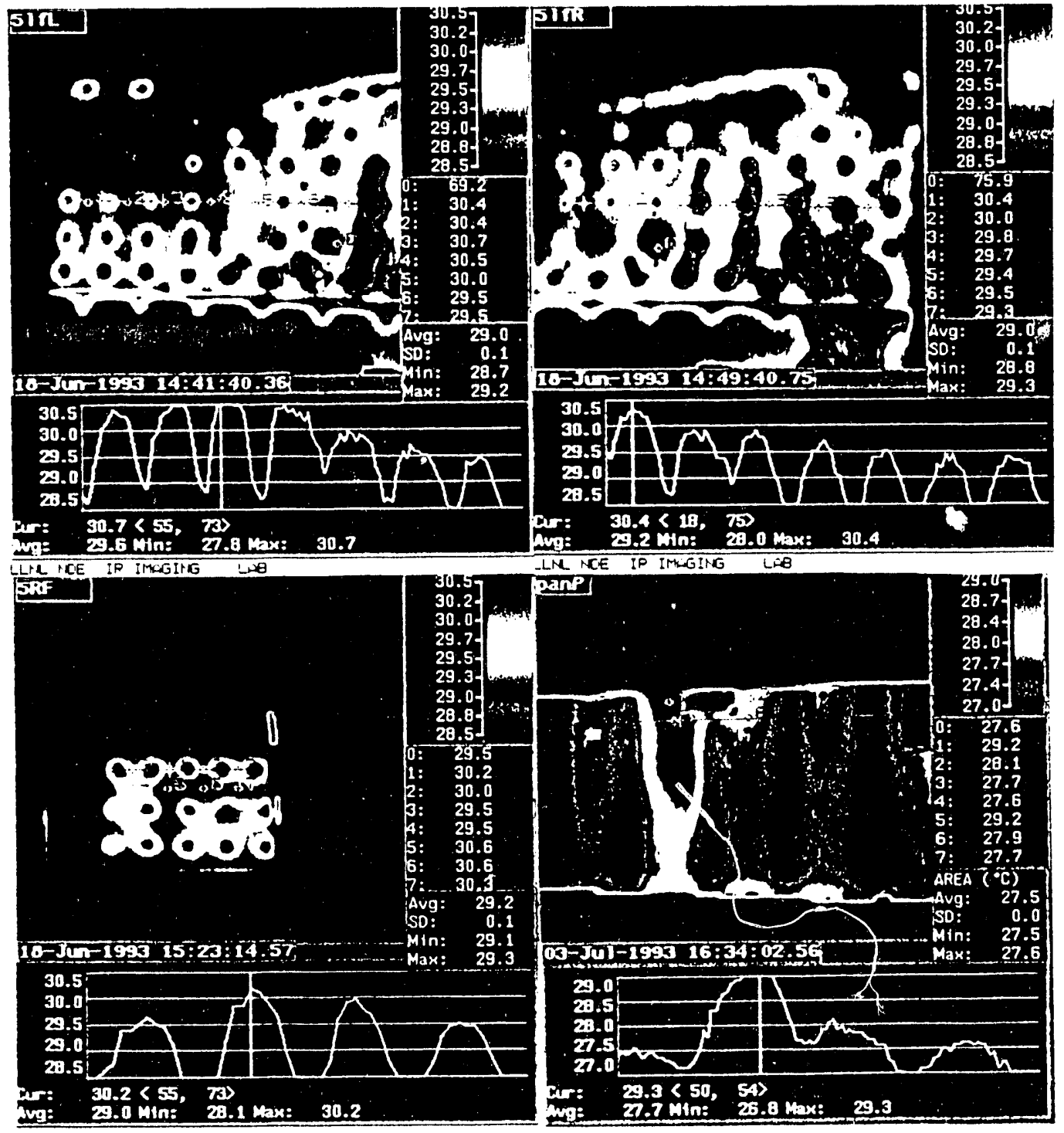

Figure C-6. Top row, left to right: two (left and right) Panel 5 left end piece images of Agema 880 DBIR System long wavelength $(10 \mu \mathrm{m})$ color-coded temperatures in ${ }^{\circ} \mathrm{C}$ at $0.4 \mathrm{~s}$ after flash. Bottom row, left: Panel 5 right end piece image of Agema 880 DBIR System long wavelength $(10 \mu \mathrm{m})$ color-coded temperatures in ${ }^{\circ} \mathrm{C}$ at $0.4 \mathrm{~s}$ after flash. Bottom row, right: F-18 wing box structure with varying amounts of material loss from corrosion used to establish the correlation between above-ambient surface temperature and aluminum channel thickness loss. Temperature data at spots 0 through 7 are included in Table 5. 


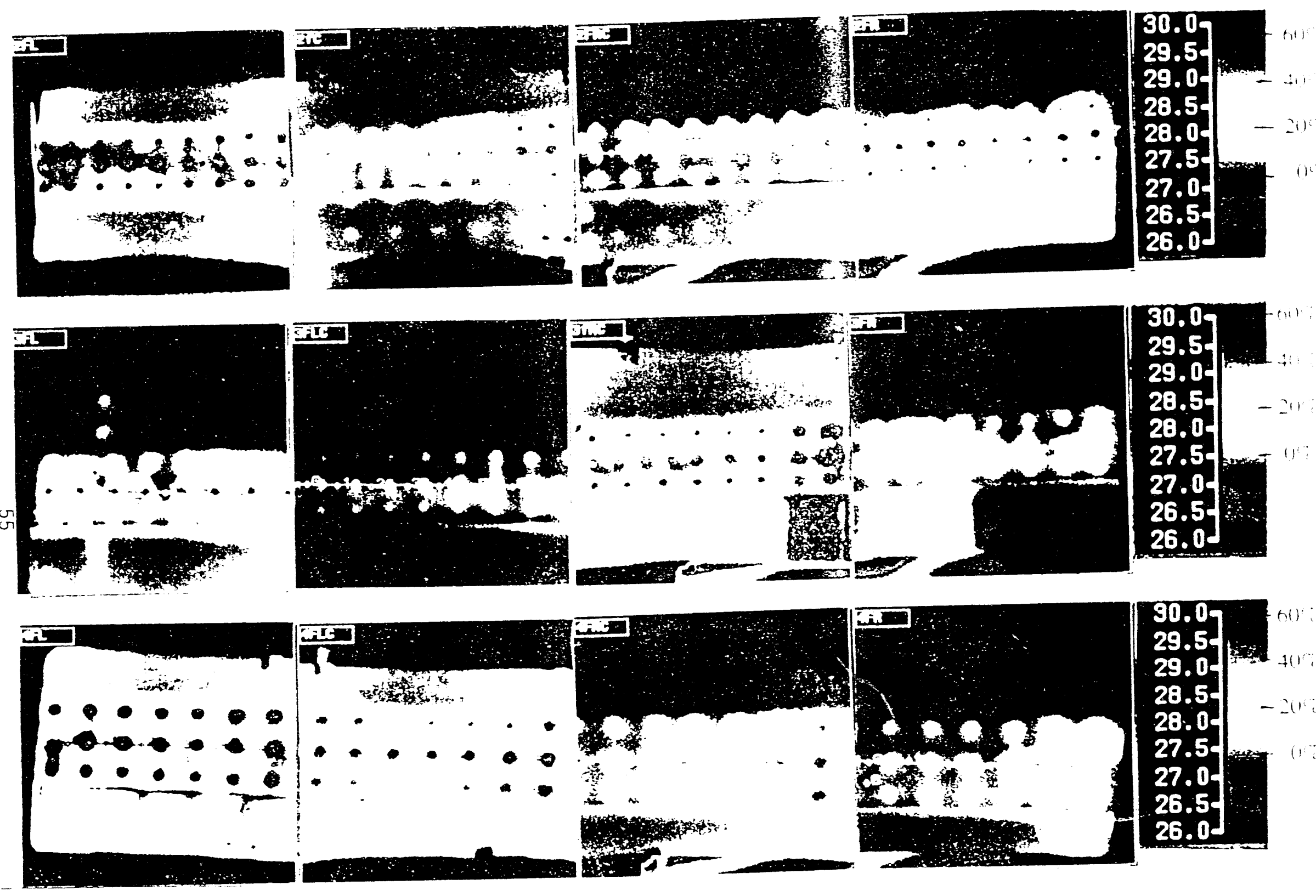

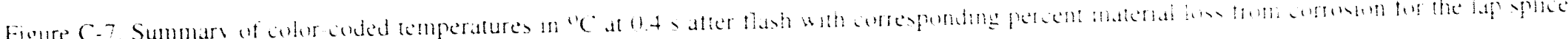

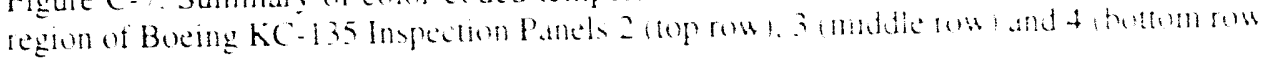



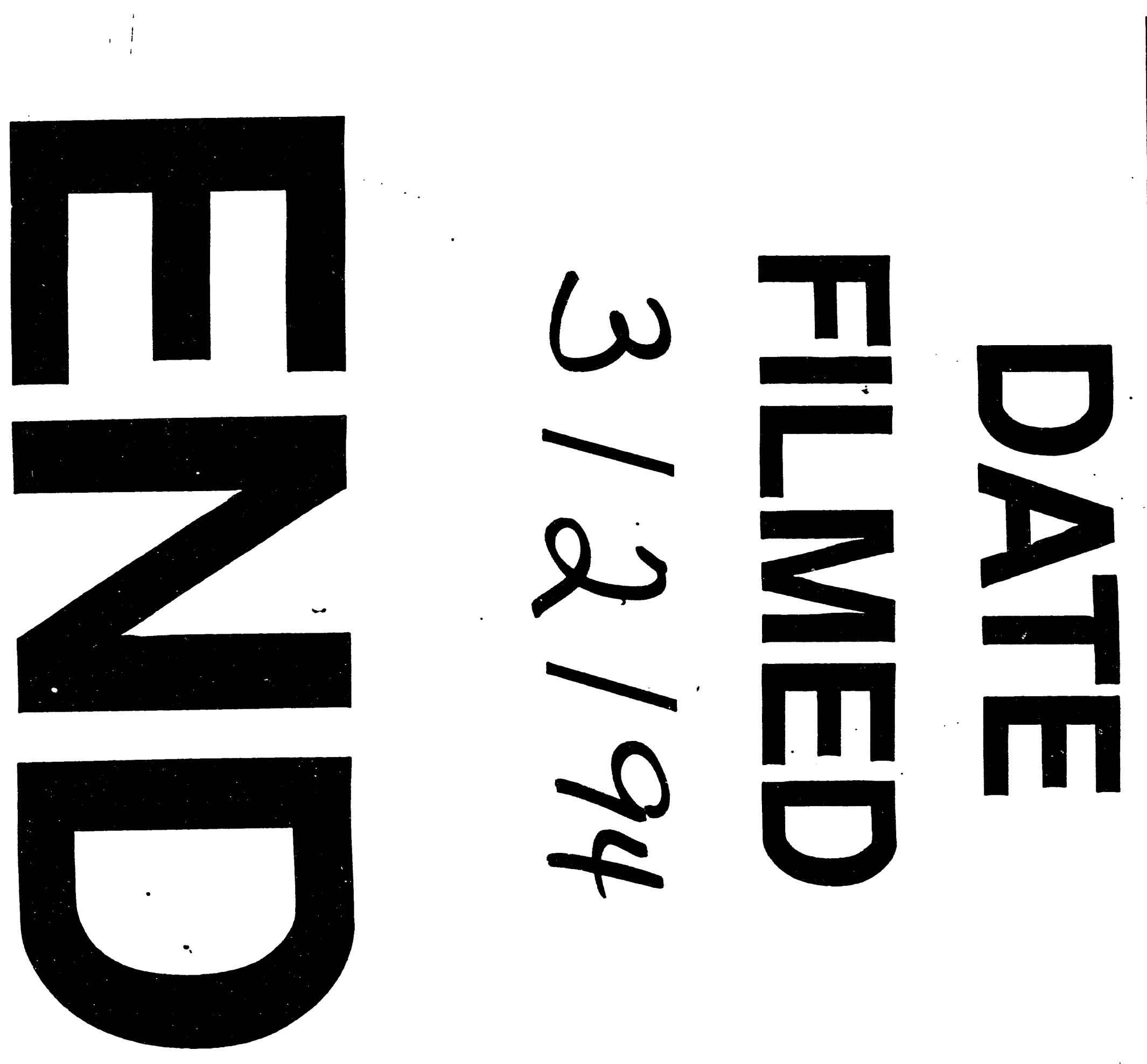


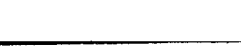

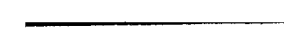

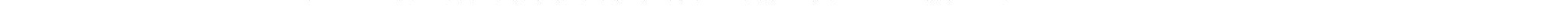
$-$ 